\title{
THE ONE-CONGRESS FICTION IN STATUTORY INTERPRETATION
}

\author{
WILLIAM W. BUZBEE ${ }^{\dagger}$
}

Reliance on fictions and simplifying assumptions in the interpretation of statutes may be inevitable, but should courts look across statutes or regulatory fields and draw inferences from linguistic choices in different statutes? In justifying such statutory comparisons and their interpretive conclusions, judges often state or imply that these linguistic comparisons reveal that Congress knows how to express itself in a more authoritative way, even where statutes were enacted by different sessions of Congress, arose out of different contexts, and concerned different subjects. This interpretive move is referred to in this Article as "the one-Congress fiction." Examination of this technique in Supreme Court jurisprudence reveals significant problems with its application, logic, and theoretical underpinnings. Furthermore, this Article's critique raises larger questions about the normative claims underpinning this and other textualist modes of statutory interpretation, particularly claims that textualism enhances the quality of legislation, reduces opportunities for ends-oriented judicial decisionmaking, and deters undemocratic manipulation of the legislative process. Central to the error of the one-Congress fiction is its implicit assumption that Congress, in legislating, is in a conversation only with itself. In reality, and as well developed in empirical and theoretical critiques of political process, the process of law enactment, implementation, and interpretation inevitably changes the implications of particular language in unpredictable ways. Far from being the product of a closed system memorialized only in the United States Code, legislation arises out of a dynamic process involving many actors. The Article concludes that a more context-sensitive method of interpreta-

† Professor of Law, Emory Law School. J.D. Columbia Law School; B.A. Amherst College. Email: wbuzbee@law.emory.edu. The author thanks Alexander Aleinikoff, Thomas Arthur, Ralph Brubaker, Lisa Chang, Daniel Farber, Philip Frickey, Michael Herz, James Hughes, Richard Lazarus, William Mayton, John Copeland Nagle, Richard Pierce, Robert Schapiro, and Peter Strauss for their suggestions, and research assistants Gordon Hamrick, Heith Rodman, Noah Benz, and Timothy Giordano for their excellent research. The author also thanks Hope Babcock, John Echeverria, Lisa Heinzerling, Katherine Gates, and Brett Frischmann for their comments and the opportunity to present an earlier draft of this paper at the Georgetown University Law Center. I especially thank Judge Stephen Williams for his incisive remarks as a commentator on that Georgetown draft. 
tion that focuses on each statute and its particular structure, genesis, and implementation history would far better serve the normative goals of textualism and conceptions of legislative supremacy than does the one-Congress fiction technique.

INTRODUCTION .173

I. ONE-CONGRESS FICTION PRECEDENTS....................................179

A. The One-Congress Fiction Defined .........................................179

B. The Supreme Court's Use of the One-Congress Fiction ................180

1. Bennett v. Spear's Multiple Statute Cross-Reference.......180

2. West Virginia University Hospitals v. Casey: Deliberate Historical Disregard....................................................189

3. FDA v. Brown $\mathcal{E}^{2}$ Williamson Tobacco Corp.: Devaluing Text and Privileging Post-Enactment

Legislative Activity

4. Other Supreme Court Examples

II. A SINGLE CONGRESS AND MULTIPLE STATUTORY MEANINGS ...204

A. A Fictional Two-Statute, Permanent Political Personnel World 206

B. Committee Turfs, Expertise, and Language Choice. 210

C. The Better Statutory Mousetrap 213

D. Electoral Politics and Language Choice .217

E. Retain or Modify $S 2$ Language? .218

III. JUSTIFICATIONS FOR THE ONE-CONGRESS FICTION?................220

A. Justifications and Interpretive Precedents. .220

1. Making Sense of the Corpus Juris and the In Pari Materia Canon . 221

2. The One-Congress Fiction and the Expressio Unius Canon Compared 225

3. The Search for Objective Meaning .229

B. The One-Congress Fiction Practice and Textualism's Justifications. .230

1. Promoting Legislative Excellence and Interstatutory Comparisons.

2. Deterring Judicial Manipulation and Interstatutory References. 236

3. Textualist Rejection of the Sounds of Legislative Silence

4. Dynamic Statutory Interpretation and the One-Congress Fiction.

C. Textualism Revisited in Light of the One-Congress Fiction ........242

IV. MODIFY OR DISCARD THE ONE-CONGRESS FICTION? .245 


\section{INTRODUCTION}

While the Constitution speaks of "a Congress" consisting of a Senate and House of Representatives, the concept of a single Congress producing legislation is undoubtedly a fiction. As reflected in the numbering of a new Congress every two years, different members, coalitions, parties, moods, and leadership change the nature of each Congress. Furthermore, changes in the White House and administrative agency leadership modify the political direction a particular Congress will pursue. Even if there were no changes in executive and legislative officeholders, shifting coalitions and the ever-changing legal and political context would create different alliances of interest groups and politicians supporting and opposing both existing laws and legislative proposals, especially where laws target diverse substantive fields.

Despite the reality of different Congresses and an inevitably shifting legal and political terrain, it is a commonplace occurrence for judges, particularly several members of the current Supreme Court, to justify a particular interpretation of a disputed statutory provision by making reference to other statutes' identical, similar, or different provisions. This cross-referencing of similarly phrased or directed provisions in different statutes is often justified with the use of the fiction that there is one Congress that knows how to achieve a certain goal or capture a certain meaning when "Congress wants" to do so, as evidenced by the referenced provisions in other statutes. This Article refers to this interpretive move as "the one-Congress fiction." Comparing provisions within a single statute to draw inferences about meaning is a well-established interpretive ploy that makes considerable sense. The interpretive methodology analyzed in this Article, in contrast, always involves comparisons of isolated provisions in at least two different statutes. These other provisions, however, are virtually always the product of a different Congress, and arise out of a different legal and social context.

That methods of statutory interpretation to varying degrees rely on fictions about politics, the legislative process, and statutory intent or meaning has been noted by many others. ${ }^{2}$ Justice Antonin Scalia,

${ }^{1}$ U.S. CoNsT. art. I, $\$ 1$.

${ }^{2}$ For an unusually strong assertion about the inevitability of uses of fictions in statutory interpretation and the indeterminacy of history, see Eben Moglen \& Richard J. Pierce, Jr., Sunstein's New Canons: Choosing the Fictions of Statutory Interpretation, 57 U. CHI. L. REV. 1203, 1205 (1990) ("[All methods of statutory interpretation] are incomplete and premised on fictions."). 
the Justice who most often makes use of the one-Congress fiction in his statutory interpretation opinions, ${ }^{3}$ concedes that such an interpretive methodology relies on a fiction. In his recently published essay, $A$ Matter of Interpretation: Federal Courts and the Law, Justice Scalia acknowledges that he follows the interpretive canon that statutes should be construed to be internally consistent, as well as "compatible with previously enacted laws." He concedes that this is just an "assum[ption]," and states that "[w]ell of course that is a fiction." Professor Popkin notes in his incisive critique of Justice Scalia's theory of statutory interpretation that Justice Scalia treats "multiple statutes as a single document written by an ideal drafter who integrates them into a super-text." ${ }^{, 6}$ This assumption of an ideal unitary drafter is, as observed by Popkin, often rooted in disregard for the realities of the context, history, and intent behind particular disputed statutory provisions. ${ }^{7}$ Professor Schacter has also noted the Court's use of interstatutory cross-referencing, leading her to comment that "it is frequently... tenuous to enlist entirely different statutes, passed by other Congresses, in an originalist search for the intended or reasonable meaning of a statute." terpretive methodology or offered critiques of related interpretive techniques, although generally in more nuanced examinations of other issues. ${ }^{9}$ Justices Frankfurter and Stevens have explicitly dis-

${ }^{3}$ See infra Part I.B.1, I.B.2, and note 119 (identifying other cases in which the oneCongress fiction is utilized).

${ }^{4}$ ANTONIN SCAlia, A Matter of INTERPRETation: FEDERAL Courts and THE LAW 16 (1997).

Id.

${ }^{6}$ William D. Popkin, An "Internal" Critique of Justice Scalia's Theory of Statutory Interpretation, 76 MINN. L. REV. 1133, 1148 (1992).

${ }^{7}$ See id. at 1148-52.

${ }^{8}$ Jane S. Schacter, The Confounding Common Law Originalism in Recent Supreme Court Statutory Interpretation: Implications for the Legislative History Debate and Beyond, 51 STAN. L. REV. 1, 32 (1998).

${ }^{9}$ See, e.g., RONALD DWORKIN, LAW's EMPIRE 313-54, 338, 349-50 (1986) (exploring statutory interpretation approaches and suggesting an interpreter should seek constructions "consistent with other legislation in force" and "take account of other decisions that Congress and the courts have made" since enacting the primary statute); William N. Eskridge, The New Textualism, 37 UCLA L. REV. 621, 661-64 (1990) (critiquing new textualist approaches "rest[ing] upon precepts of grammar and logic, proceduralism, and federalism"); William Funk, Review Essay: Faith in Texts-Justice Scalia's Interpretation of Statutes and the Constitution: Apostasy for the Rest of Us?, 49 ADMIN. L. REV. 825, 845-46 (1997) (describing Justice Scalia's textualism as rooted in the objective meaning of statutes and suggesting that such an approach provides little guidance when the primary statutory text "truly remains ambiguous"); Bradley C. Karkkainen, "Plain Meaning": Justice Scalia's Jurisprudence of Strict Statutory Construction, 17 HARV. J.L. 
agreed with the practice of looking at laws as though all were enacted by a "single draftsman." Former Judge Wald of the D.C. Circuit simi-

\& PUB. Pol'Y 401, 407 (1994) (referring to the idea that a statute's meaning should be "most compatible with the surrounding body of law into which the provision must be integrated" as a "benign fiction"); Jerry L. Mashaw, Textualism, Constitutionalism, and the Interpretation of Federal Statutes, 32 WM. \& MARY L. REV. 827, 835-36 (1991) (exploring textualists' "acontextual approach" and suggesting that emphasizing text over legislative history can increase "the flexibility of statutes"); Richard J. Pierce, Jr., The Supreme Court's New Hypertextualism: An Invitation to Cacophony and Incoherence in the Administrative State, 95 ColuM. L. REV. 749, 76476 (1995) (criticizing the Court's "hypertextualism" and arguing in general discussion and through analysis of one hundred years of trucking regulation and related constitutional law that individual statutes and laws enacted over time are likely to be construed in disruptive ways if courts look at text to the exclusion of implementation history and agencies' many attempts to juggle complicated interrelated provisions); Peter L. Strauss, The Courts and the Congress: Should Judges Disdain Political History?, 98 CoLUM. L. REV. 242, 245 (1998) (warning that we should be "cautious about proposing principles of interpretation that ... devalue knowing the context within which the legislature has spoken"); Patricia M. Wald, The Sizzling Sleeper: The Use of Legislative History in Construing Statutes in the 1988-89 Term of the United States Supreme Court, 39 AM. U. L. REV. 277, 307 (1990) (attempting to dispel the notion that a "yes" vote on a particular bill indicates that the legislator "intends to give approval to and put imprimatur on ... the language of the statute ...," and questioning interpretive approaches built upon a contrary assumption); Nicholas S. Zeppos, Chief Justice Rehnquist, the Two Faces of Ultra-Pluralism, and the Originalist Fallacy, 25 RUTGERS L.J. 679, 681-82 (1994) (arguing that "[ $t$ ] he subsequent legislative history and more recently enacted statutes increase the sources of interpretive information and require the judge to inject fewer of her personal opinions," but characterizing such a technique as "dynamic pluralis[m]"); Nicholas S. Zeppos, Justice Scalia's Textualism: The "New" New Legal Process, 12 CARDOzo L. REv. 1597, 1615, 1620-22 (1991) [hereinafter Zeppos, Justice Scalia's Textualism] (commenting that Justice Scalia's textualism goes beyond "the enacted statute" to examine "the text of other related statutes" and also noting that Scalia "views the entire United States Code ... as a product of a perfectly rational[,] ... sensible[, and] ... omniscient legislature" that creates "a coherent and consistent product over time"); Nicholas S. Zeppos, The Use of Authority in Statutory Interpretation: An Empirical Analysis, 70 TEX. L. REv. 1073, 1085 (1992) [hereinafter Zeppos, The Use of Authority] (implicitly impugning interpretive methodologies that are predicated on notions contrary to the concept that "[legislative outcomes] are entirely random or fortuitous, largely dependent on who controls the legislative agenda"). Thomas Merrill has also commented on such interpretive techniques:

[M] ]any of the interpretative techniques relied upon most extensively by Justice Scalia presuppose "a rational or omniscient legislature," rather than a legislature of ad hoc bargains. Included here would be the assumptions that Congress is a perfect grammarian, that different provisions of a statute reflect a single, unified structure, that words are used the same way in different statutes, and that Congress is familiar with all provisions in the United States Code.

Thomas W. Merrill, Chief Justice Rehnquist, Pluralist Theory, and the Interpretation of Statutes, 25 RUTGERS L.J. 621, 662 (1994) (citations omitted). For a superb textbook flagging of questions about this and several related interpretive techniques, see WILILAM N. ESKRIDGE, JR. \& PHILIP P. FRICKEY, LEGISLATION: STATUTES AND THE CREATION OF PUBLIC POLICY 832, 839-42 (2d ed. 1995).

"United States v. Monia, 317 U.S. 424, 444 (1943) (Frankfurter, J., dissenting) ("If 
larly has stated that the belief of courts that Congress "know[s] the state of the law when it legislates" rests on "tenuous" assumptions." Justice Scalia appears to be the member of the current Supreme Court most inclined to make use of the one-Congress fiction interpretive approach, but other current justices have also authored opinions making use of the one-Congress fiction in comparing different statutes' provisions.

Judges and justices are not alone in using the one-Congress fiction to derive statutory meaning from a difficult statutory text. Several prominent academics, chief among them Professor William Eskridge and former Yale Law Dean and current judge Guido Calabresi, have advocated modes of statutory interpretation that, if followed by courts, would allow a more continuous judicial updating of statutory meaning based on changing political mores without requiring actual textual change. ${ }^{12}$ While Eskridge, in particular, is among the more pointed critics of both Justice Scalia and textualists generally, his call for "dynamic" interpretation at times seems to rely on the idea that Congress, or perhaps society, is a unitary principal whose changing views should be heeded by its agents, generally courts and administrative agencies. ${ }^{13}$

This Article examines the one-Congress fiction in statutory interpretation, both critiquing the practice itself and using this critique to explore more deeply the empirical underpinnings and normative claims used to justify this and other textualist analytical approaches. In particular, this Article builds on recent empirical and theoretical explorations of the legislative process to illustrate problems with the one-Congress fiction and related textualist modes of interpretation. This interpretive practice gives judges a Herculean interpretive task of making sense of the law as a whole, and may free them to engage in just the kind of unpredictable and unprincipled ends-oriented interpretation so vehemently criticized by advocates of textualist methods of interpretation. Furthermore, due to inherent difficulties in predicting when and how the one-Congress fiction will be used, the oneCongress fiction threatens to be used as a sort of random and roving

a single draftsman had drafted each of these provisions in all seventeen statutes, there might be some reason for believing that the difference in language reflected a difference in meaning."). Justice Stevens's rejection of such an assumption is also evident in numerous cases. See infra notes 75-76 and accompanying text (discussing Justice Stevens's approach and contrasting it with the one-Congress fiction).

${ }^{11}$ Patricia M. Wald, Some Observations on the Use of Legislative History in the $1981 \mathrm{Su}$ preme Court Term, 68 IOWA L. REV. 195, 213 (1983).

12 GUTDO CALABRESI, A COMMON LAW FOR THE AGE OF STATUTES (1982); WILIIAM N. ESKRIDGE, JR., DYNAMIC STATUTORY INIERPRETATION (1994).

${ }^{13}$ See ESKRIDGE, supra note 12 , at 52-55. 
"clear statement" doctrine. The courts may engage in interstatutory comparisons, but unlike "clear statement" approaches, which courts tend to apply when central constitutional values are implicated, the one-Congress fiction may be random and roving because neither legislative actors nor litigators can predict what statutory comparisons will be made or what inferences are likely to be drawn from vague or omitted language.

Part I begins by reviewing decisions of the Supreme Court from the last decade in which opinions relied on the one-Congress fiction by comparing language usage in the "primary" (or disputed) statutory provision with language in other statutes (the "referents"). At times the Court views similar language as revealing a common congressional practice, view, or understanding, while in other cases slight variations in similar language are given great weight in justifying divergent interpretations of seemingly similar language. However, the Court has seldom engaged in more than a cursory examination of the comparable texts' context, structure, and history. Even if the comparison of statutes is inevitable, rarely have such comparisons been made through the scrutiny of more than isolated text alone.

Part II examines the dynamics of the legislative process, drawing on the growing and increasingly sophisticated empirical and theoretical analyses of politics and the legislative process. The Article establishes that not only is the one-Congress fiction not rooted in American political reality, but its implicit assumptions are also contradicted by most scholarly examinations of legislation and the legislative process, including central tenets of public choice theory that have driven much of the resurgence of textualist modes of interpretation. Even if one engages in a counterfactual simplifying assumption of two laws enacted during a period in which personnel in the White House, agencies, and Congress did not change, it is difficult to come up with a sound rationale for why examination of cross-referenced provisions in different statutes sheds any kind of reliable light on the meaning of either law.

Part III seeks to derive a sympathetic explanation for the oneCongress fiction interpretive methodology. This Part both highlights similarities between this fiction and other well established interpretive approaches and canons and reviews ways in which such an approach arguably furthers some public-regarding instrumental goals. This section gives particular attention to how the one-Congress fiction shares attributes with the in pari materia interpretive canon but is ultimately significantly distinguishable. Part III also shows that this interpretive 
technique is in substantial tension with several stated goals of advocates of textualism. In particular, textualists justify their methodology in part with claims that their favored approach reduces opportunities for ends-oriented activist judicial decisionmaking. As the number of texts that can be relied upon expands, however, mere reference to isolated statutory referents without consideration of historical and statutory context actually expands indeterminacy and judicial discretion. Reliance on multiple statutory texts alone gives courts substantial latitude, much as does excessive reliance on legislative history, to pick out comparable language and to use unpredictable interpretive inferences to reach desired policy ends. Each construction of the comparable provision in a second statute by the Supreme Court also creates dicta that can guide or perhaps even modify future interpretations of that second statute. This Part also briefly compares the proposals of scholarly advocates of dynamic interpretive methods, which would allow for judicial updating of static statutory texts even where statutory language remains unchanged.

Part IV ultimately argues that the one-Congress fiction in statutory interpretation should only be used warily, paying much greater attention to the whole context out of which the primary statutory provision and referent provisions arose. Greater attention should be paid to interpretive cues within each statute, with no presumption that similar or isolated language always means the same thing or that different language in different statutes should be interpreted to reveal diverse meanings. Underlying this Article's normative argument is the belief that courts and agencies should give heed to each statute's language, structure, and historical context and reward drafters' attention to all interpretive cues and statements of purpose reflected in a statute's text. Judicial scrutiny of a statute's historical context, especially of historical materials that are not "self-referential" ${ }^{\text {it }}$ and subject to manipulation, also would show greater respect for traditional concepts of legislative supremacy than does the comparison of isolated text provisions alone.

The practice of judicial reference to an array of earlier (or even later) statutes to interpret a disputed provision may in fact undercut

${ }^{14}$ By "self-referential" materials, this Article refers to historical materials that reflect a legislator's or other political actor's efforts to explain what he or she meant. Attention to historical context that is not self-referential, in contrast, refers to analysis of other forms of information about the historical context of a particular disputed statutory provision, such as past judicial opinions, prevalent drafting strategies at that time, earlier statutes addressing the same subject matter, and previous agency actions. 
the legislative process. Use of the one-Congress fiction by the judiciary reduces the value of each legislative bargain since each legislative coalition succeeding in enacting a law can predict neither what statutes will be used for purposes of comparison nor whether similar but slightly varied language will be construed to reveal a consistent or different meaning. The Article concludes that while interpretive assumptions or fictions are often unavoidable in statutory interpretation methodology, the one-Congress fiction rests on premises that are contrary to reality and should be largely abandoned. Even for advocates of textualist modes of interpretation, the one-Congress fiction should be recognized as an unsound text-based interpretive technique.

The United States Code is only one source of law, with other legal developments outside of the Code influencing future efforts to change those portions of the law placed in the Code. The world of statutes is not a closed system in which only Congress influences the import of each legal enactment. Congress enacts laws in different periods, to be implemented by different agencies and administrations, against a different backdrop of case law, statutes, and agency regulation. Different interpretive communities are both the targets of legislative initiatives and participants in the legislative process. Exclusively text-based comparisons of isolated statutory provisions reflect an impoverished and politically unrealistic view of legislation and the legislative process.

\section{ONE-CONGRESS FICTION PRECEDENTS}

This Part explains in greater detail the meaning of the oneCongress fiction, first explaining the basic interpretive ploy, and then analyzing recent Supreme Court cases in which this interpretive approach was used. This Part's case analysis sets the stage for the theoretical and normative critique that follows.

\section{A. The One-Congress Fiction Defined}

In this Article, "the one-Congress fiction" is used as a shorthand term to refer to the following statutory interpretation methodology. The primary statute, "S1," is the subject of an interpretive dispute before the courts. Another statute, which this Article will refer to as the "cross-referenced" provision or the "referent," and later as "S2," contains language that due to its similar purpose or its word choice is viewed by the court as helpful in interpreting the primary statute. To justify this interpretive comparison, courts either implicitly or explic- 
itly consider the presence or absence of particular language in the primary and referent provisions as revealing a particular meaning or legislative intent. Despite Congress's collective nature, it is sometimes anthropomorphized, in the sense that courts make interpretive conclusions based on Congress's assumed knowledge that, like a single human being, if it wants to achieve a particular end, it knows how to do so, as evidenced by Statute 2's (S2's) language. This technique also at times appears to reflect justices' preference for objective or plain meaning, with an expectation that the legislature will produce a United States Code that is "a coherent and consistent product over time."

\section{B. The Supreme Court's Use of the One-Congress Fiction}

The United States Supreme Court has in recent years made frequent use of the one-Congress fiction in its statutory interpretation cases. The practice appears most frequently in the opinions of Justice Scalia, but he is not alone in adopting this interpretive methodology. This section reviews a cross section of cases from the last decade in which the Court used the one-Congress fiction. Three cases-Bennett v. Spear, ${ }^{16}$ West Virginia University Hospitals, Inc. v. Casey, ${ }^{17}$ and FDA v. Brown $\mathcal{E}^{\circ}$ Williamson Tobacco Corp. ${ }^{18}$ - are examined and reveal that different interpretive approaches and greater examination of historical context often lead to different and more persuasive conclusions. The Article then examines a handful of additional cases in which the oneCongress fiction has been used, often in ways vulnerable to criticism. This section, and the Article as a whole, focus primarily upon statutory interpretation cases arising in connection with laws implicating structures and power in the administrative state.

\section{Bennett v. Spear's Multiple Statute Cross-Reference}

In Bennett, one of the Supreme Court's many recent forays into the law of standing, ${ }^{19}$ the Court unanimously concluded in an opinion by Justice Scalia that a group of commercial water users in the West satisfied both prudential "zone of interest" and constitutional standing

${ }^{15}$ Zeppos, Justice Scalia's Textualism, supra note 9, at 1621-22 (citation omitted).

${ }^{16}$ 520 U.S. 154 (1997).

17499 U.S. 83 (1991).

18120 S. Ct. $1291(2000)$.

${ }^{19}$ For a recent critique of the Supreme Court's politicized standing jurisprudence, see Richard J. Pierce, Jr., Is Standing Law or Politics?, 77 N.C. L. REV. 1741 (1999). 
tests in bringing their challenge to water usage restrictions imposed in light of Endangered Species Act ("ESA") requirements. The Court thus allowed them to bring their challenge under the ESA's "citizen suit" provision even though they were seeking to constrain agency actions designed to further protections for two endangered fish present in reservoir waters. ${ }^{20}$ In contrast to recent cases in which Justice Scalia found (or would have found) litigants to lack standing despite explicit statutory conferral of a cause of action, Justice Scalia found in Bennett that petitioners easily satisfied all standing criteria.

The one-Congress fiction interpretive methodology appears in the Court's discussion of the "zone of interests" standing test. ${ }^{21}$ Most federal environmental laws contain citizen suit provisions, but their exact language, while often similar, varies from statute to statute. ${ }^{22}$ The Bennett Court inquired "whether the ESA's citizen-suit provision ... negates the zone-of-interests test (or, perhaps more accurately, expands the zone of interests). ${ }^{23}$ The Court concluded that it did, justifying its determination by comparing the ESA to other statutory provisions, predominately, but not exclusively, from the environmental law area. Justice Scalia quoted the ESA's language-that "'any person may commence a civil suit" -and stated that this is language "of remarkable breadth when compared with the language Congress ordinarily uses. ${ }^{24}$ He continued this interstatutory comparison, stating that "[e]ven in some other environmental statutes, Congress has used more restrictive formulations, such as '[any person] having an

$\because "$ See 520 U.S. at 161-74. The lower court had found that due to the commercial interests underlying these plaintiffs' challenge, they were not within the "zone of interests" manifest in the ESA, although they arguably fell within the textual letter of the statute's broad citizen suit provision. See Bennett v. Plenert, No. 93-6076-HO, $1993 \mathrm{WL}$ 669429 , at *5 (D. Or. Nov. 18, 1993) (“[T] he recreational, aesthetic, and commercial interests advanced by plaintiffs do not fall within the zone of interests sought to be protected by ESA."). In responding to the lower court's opinion and the petitioners' arguments against such an application of the prudential zone of interests test, Justice Scalia was confronted with a garbled line of Supreme Court zone of interest cases, plus a few other cases arising under the ESA in which he himself had written opinions revealing both interpretive approaches to the Act and his approach to environmental standing cases.

21 See Bennett, 520 U.S. at 165-66.

22 Reasons for such variation in this particular context, as well as in the general run of cases, is explored in greater depth below, but the most obvious reasons for this variation in similarly-operating provisions are their different years of enactment and legislators' adoption of language that best dovetails with relevant background law as revealed not just in other statutes' texts, but also in agency interpretations and judicial opinions.

\footnotetext{
520 U.S. at 164.

24 Id. at $164-65$.
} 
interest which is or may be adversely affected" in the Clean Water Act and similar language in the Surface Mining Control and Reclamation Act; " "[a]ny person suffering legal wrong"" in the Energy Supply and Environmental Coordination Act; and "'any person having a valid legal interest which is or may be adversely affected ... whenever such action constitutes a cases or controversy," as stated in the Ocean Thermal Energy Conversion Act. ${ }^{25}$ He further contrasted the ESA's language with language in statutes granting causes of action in the context of unfair trade practices and other commercial matters. ${ }^{26}$

In the next paragraph, the Court further buttressed its conclusion by looking at the purpose of this statutory provision. The Court stated that much as the Court in Trafficante v. Metropolitan Life Insurance $\mathrm{Co}^{27}$ allowed standing to allow citizen litigation "to the full extent permitted by Article III by [a provision] of the Civil Rights Act of 1968 ... that authorized 'any person who claims to have been injured by a discriminatory housing practice,' to sue for violations of the Act, ${ }^{28}$ the Court in Bennett felt justified in similarly expanding prudential standing to the extent allowed by Article III: "[t]he statutory language here is even clearer, and the subject of the legislation makes the intent to permit enforcement by every man even more plausible." ${ }^{29}$

The Court's conclusion about the evident breadth of the ESA's citizen suit language is well justified. The provision is broad and unnarrowed by any qualifying language. The statute does manifest strong legislative goals and explicitly seeks to enlist citizen action in furtherance of its statutory goals. As the unanimous Court concluded, the statute's text does not distinguish between citizens seeking to prod government officials to take actions protecting endangered species and citizens acting in furtherance of economic goals who seek to challenge government officials' actions. ${ }^{30}$ What is far less self-evident than

${ }^{25}$ Id. at 165 .

${ }^{26} \mathrm{Id}$.

27409 U.S. 205 (1972), cited in Bennett, 520 U.S. at 165-66.

${ }^{28}$ Bennett, 520 U.S. at 165-66.

29 Id. at 166 . This comparison of the ESA to other statutes notably includes a reference to legislative "intent," not meaning, although in other contexts Justice Scalia has shunned any references to legislative intent. See SCALIA, supra note 4, at 16-18 (criticizing interpretive methods that focus on legislative intent and arguing for a focus on what the "lawgiver promulgated").

${ }^{30}$ Although the Court's opinion discusses the ESA's broad citizen suit provision and definition of "person[s]" authorized to bring or be the subject of such suits, the opinion does not reflect any possible investigation into the actual history of this statutory provision. The definition of "person" in 16 U.S.C. $§ 1532$ (c) was amended once 
assumed by the unanimous Court is that the various referent statutory provisions reflect a different meaning, or a significantly different legislative intent, namely to circumscribe the classes of allowable plaintiffs. ${ }^{31}$ It is also far from obvious that this comparison appropriately allows one to make a firmer conclusion about statutory meaning or congressional intent. The Court merely compared statutory language in isolated provisions, only considering the possible influence of its own past statutory interpretations in its reference to Trafficante. ${ }^{32}$

What would the Court have found if it had investigated the historical roots of the ESA and the referent provisions alluded to in Bennett? The Court's reference to statutes that both preceded and followed the enactment of the ESA reveals a lack of concern with what an ideal Congress would have considered or known in enacting the ESA. Examination of the referent statutes' causes of action reveals virtually no basis for the Court's comparison conclusions, and in fact casts serious doubt on the appropriateness of the Court's apparent conclusion or, rather, assumption, that these other provisions reveal a legislative intent to use prudential standing hurdles to allow only a more limited group of litigants into court.

The ESA's citizen suit provision and the linked definitional provisions were both contained in the ESA as initially enacted in $1973 .^{33}$ The Bennett opinion's cross-referenced provisions included several statutes enacted after the ESA, provisions that thus could not have been actually known to, or constructively known to, the Congress that

subsequent to the ESA's enactment in 1973 following a court decision limiting the law's application to municipalities. See 134 CONG. REC. 18,571 (1988) (statement of Senator Mitchell) (explaining the addition of this language as necessary to rectify appellate court's interpretation of the ESA in United States v. City of Rancho Palos Verdes, 841 F.2d 329 (9th Cir. 1988)).

"References to legislative "intent" or statutory "meaning" are undoubtedly terms of art that have led to the writing of many an article and opinion. This Article generally uses the term "meaning," but to avoid linguistic awkwardness at times refers to judicial attempts to discern legislative "intent." Justice Scalia himself, in Bennett, either slips in referring to legislative "intent" or also finds such references on occasion to be unavoidable. See supra note 29 and accompanying text.

*2 In construing the referent statutory provisions as narrower than the ESA for "zone of interests" test purposes, the Court's use of the one-Congress fiction in Bennett also provided dicta for future litigants or judges seeking to narrow the reach of those referent provisions. See infra note 244 and accompanying text (discussing the risk that dicta will unsettle existing law and empower politicized judges).

${ }^{33}$ Endangered Species Act of 1973, Pub. L. No. 93-205, § 11, 87 Stat. 884 (1973) (codified at 16 U.S.C. $\$ 1539$ (1994)). The definition of person was changed in minor ways subsequent to 1973, but for purposes of the Bennett analysis and this Article's critique, the relevant language dates from 1973. 
enacted the ESA. ${ }^{34}$ If the Court is searching for a consistent interpretive methodology, it cannot rest here on any actual or constructive state of legislative knowledge. ${ }^{35}$ The omniscient unitary concept noted in past scholarship of Professors Zeppos and Popkin appears to assume the fiction of a drafter who has knowledge of the past and future, or at least drafts in an invariably coherent and consistent manner. ${ }^{36}$

Putting to the side for the moment whether the one-Congress fiction technique should ever include analysis of referents that post-date the primary statute's disputed provision, analysis of the historical context of most of these laws undercuts the Bennett Court's assumptions. The environmental law engendering the greatest volume of citizen litigation has been the Clean Water Act ("CWA"). ${ }^{37}$ The Bennett opinion assumed that the provision of the CWA providing a citizen suit for persons "having an interest which is or may be adversely affected" vealed a more narrowly crafted cause of action, or at least a legislatively intended narrower "zone." The Court indicated that unlike the ESA, the CWA does not reveal an intent to expand standing to the limit of Article III constitutional criteria, and thus, by implication, does not eliminate the "zone of interest" prudential hurdle as does the $\mathrm{ESA}^{39}$ The problem with this assumption is readily apparent when

34 The referenced Surface Mining law dates from 1977, the Energy Supply statute from 1974, and the Ocean Thermal law from 1980. See 30 U.S.C. $\$ 1270$ (a) (1994) (Surface Mining law); 15 U.S.C. $§ 797$ (b) (5) (1994) (Energy Supply statute); 42 U.S.C. $\S 9124$ (a) (1994) (Ocean Thermal law). The other referenced statutory provisions pre-date the ESA.

${ }^{35}$ For textualists, the elaboration of, and hewing to, a consistent interpretive methodology is an important justification for their preferred mode of statutory construction. See Finley v. United States, 490 U.S. 545, 556 (1989) (Scalia, J.) ("What is of paramount importance is that Congress be able to legislate against a background of clear interpretive rules, so that it may know the effect of the language it adopts."). This textualist goal is explored by Jane S. Schacter in her article Metademocracy: The Changing Structure of Legitimacy in Statutory Interpretation, 108 HARV. L. REV. 593, 600 \& n.25 (1995) (referring to the above proposition articulated by Justice Scalia as "highly questionable"). See infra notes $170-73$ and accompanying text (exploring the rationale for the use of consistent interpretive conventions).

${ }^{36}$ As discussed below, Justice Scalia has in other cases knowingly used oneCongress fiction statutory referents that post-date the primary text. See, e.g., W. Va. Univ. Hosps., Inc. v. Casey, 499 U.S. 83, 100-01 (1991) (discussing his examination of pre- and post-enactment referents and acknowledging that such a practice does not rest on actual or constructive knowledge of a particular Congress: "how could an earlier Congress know what a later Congress would enact?").

${ }^{37}$ The Federal Water Pollution and Control Act, 33 U.S.C. $\$ \$ 1251-1384$ (1994).

38 33 U.S.C. $\$ 1365$ (g) (1994).

${ }^{39}$ See Bennett v. Spear, 520 U.S. 154, 165 (1997) (“[I]n some other environmental 
one examines the historical context of the CWA's enactment. Floor debates, committee reports, and legislative battles over proposed language indicate that a narrower cause of action was considered but rejected. ${ }^{* 0}$ Perhaps of greater significance, an examination of the legislative history as well as relevant law interpretations of coordinate branches, here the Supreme Court's 1972 opinion in Sierra Club v. Morton, ${ }^{41}$ reveal that the language chosen appears closely to parrot the standing minima that had most recently been articulated by the Supreme Court prior to the CWA's enactment. Legislators indicated knowledge of the Court's ruling that citizens suing must have suffered "injury-in-fact." ${ }^{\$ 2}$ Even if one rejects the validity of any reference to legislative history to glean statutory meaning, and instead analyzes statutory language as it would have been understood at the time of enactment, the Court's own articulation of standing prerequisites was part of the historical context of the CWA's enactment and would have been considered by an ideal drafter, as it apparently was in reality. ${ }^{43}$

statutes [besides the ESA], Congress has used more restrictive [standing] formulations, such as '[any person] having an interest which is or may be adversely affected.' 33 U.S.C. $\$ 1365$ (g) (Clean Water Act).”).

4" The rejected language would have limited the definition of "citizen" to persons who lived in the geographic area where a violation of the statute occurred and who were directly affected by the violation, or groups participating in the administrative proceedings surrounding a case. See H.R. 11896, 92d Cong. (1972), reprinted in H.R. REP. No. 92-911, at 132-34 (1972). This restrictive language was removed at the conference committee stage in favor of the language that ended up in the law. See S. REP. No. 92-1236, at 146 (1972), reprinted in 1972 U.S.C.C.A.N. 3668, 3823. One legislator's floor statement expressed his support for removing the "very limiting restrictions the House bill had placed on citizen suits" so as "not to prevent any legitimately concerned citizen or group from bringing suit to prevent the law from being violated." 118 CONG. REC. 33,716 (1972) (statement of Sen. Bayh).

405 U.S. 727 (1972) (Stewart, J.) (holding that a person has standing to bring suit under the Administrative Procedure Act ("APA") only if he himself has suffered or will suffer an injury).

${ }^{42}$ The Senate Conference Report explicitly referenced this case, stating that the statutory language chosen was meant to "reflect" the Supreme Court's standing criteria. S. REP. No. 92-1236, at 146. Senator Muskie, then Chairman of the Senate Subcommittee on Air and Water Pollution and a conference committee member on the CWA bill, explained the statutory language in terms much like that in Sierra Club. "Thus under the language agreed to by the Conference a citizen suit may be brought only by those persons or groups which are among those whose interest (whether environmental or economic) is or may be injured by the violation of the Act." 118 CoNG. REC. 33,700 (1972) (statement of Sen. Muskie). In Sierra Club, the Court stated that constitutionally sufficient injury in fact could include injuries to "aesthetic or environmental well-being, like economic well-being," 405 U.S. at 734.

4. One quirk in this argument is that Sierra Club's articulation of the "injury-in-fact" requirement and the types of interests that would suffice for standing arose in what appears to have been a judicial construction of the APA's judicial review provisions. 405 U.S. at 734 ("We do not question that [aesthetic and ecological] harm may 
Furthermore, subsequent to the decision in Sierra Club, the Court construed the CWA's language to "allow suits by all persons possessing standing under this Court's decision in Sierra Club," CWA standing without any mention of prudential standing limitations and with explicit reference to Article III as the only relevant standing criterion. ${ }^{45}$ Scholarly analyses of CWA citizen suits and lower court opinions appear uniformly to have construed the CWA as only requiring citizens to meet constitutional standing requirements. ${ }^{46}$ Bennett's

amount to an 'injury in fact' sufficient to lay the basis for standing under $\$ 10$ of the APA."). Subsequent to Sierra Club, the Court has stated that the "injury-in-fact" is and has been the constitutional minimum for standing. See Lujan v. Defenders of Wildlife, 504 U.S. 555, 560 (1992) (articulating this proposition). At the time of Sierra Club, it appears that most courts and likely most legislators did not foresee that the Constitution would act as a barrier to standing if Congress had conferred an explicit cause of action. See Cass R. Sunstein, What's Standing After Lujan? Of Citizen Suits, "Injuries," and Article III, 91 MrCH. L. REv. 163, 193 (1992) ("[During the time it enacted several citizen-suit provisions,] Congress did not ... devote much attention to the constitutionality of citizen standing, and the issue was to remain open for many years."). For extensive citation to many articles critiquing Lujan, see William W. Buzbee, Expanding the Zone, Tilting the Field: Zone of Interests and Article II Standing Analysis After Bennett v. Spear, 49 ADMIN. L. REv. 763, 790 n.138 (1997).

44 Middlesex County Sewerage Auth. v. Nat'l Sea Clammers Ass'n, 453 U.S. 1, 16 (1981).

45. In Gwaltney of Smithfield, Ltd. v. Chesapeake Bay Foundation, the Court further analyzed the CWA's citizen suit provision as limited only by the now established Article III threshold. 484 U.S. 49, 56-67 (1987) (discussing the CWA and standing, and making reference to Article III without mention of prudential standing limitations).

${ }^{46}$ I use the term "appear" because a few cases finesse the meaning of Sierra Club by referring to its standing criteria, but without identifying the injury-in-fact requirement as either APA-based or constitutionally derived. No case of which this author is aware, however, has ever construed the CWA as enacting a citizen suit provision that provides additional prudential standing criteria on top of the now constitutional injury-in-fact test. See, e.g., Pub. Interest Research Group of N.J., Inc. v. Magnesium Elektron, Inc., 123 F.3d 111, 122 (3d Cir. 1997) (interpreting the "adversely affected" language of the CWA citizen suit provision as limiting standing to the "injury prong of the constitutional test"); Pub. Interest Research Group of N.J., Inc. v. Powell Duffryn Terminals Inc., 913 F.2d 64, 70 n.3 (3d Cir. 1990) (explicitly disregarding prudential standing limitations within the CWA citizen suit context based on the legislative history surrounding the Act); Chesapeake Bay Found. v. Am. Recovery Co., 769 F.2d 207, 209 (4th Cir. 1985) (assuming that the standing requirements for a "citizen" under the CWA were meant to be coextensive with the Morton test); Sierra Club v. SCM Corp., 747 F.2d 99, 104-05 (2d Cir. 1984) (concluding that the CWA's definition of "citizen" for purposes of standing applies to all persons who meet the injury-in-fact test enunciated in Morton); Gonzales v. Gorsuch, 688 F.2d 1263, 1266-68 (9th Cir. 1982) (noting that there is a "liberal personal stake requirement applicable to environmental plaintiffs" and assessing CWA citizen suit standing under the Morton injury-in-fact test without mentioning prudential considerations).

District court decisions reflect the same interpretation. See, e.g., Student Pub. Interest Research Group of N.J., Inc. v. Monsanto Co., 600 F. Supp. 1479, 1484 (D.N.J. 1985) (holding that an environmental organization had standing to sue under the 
cross-reference to the CWA as evidencing a narrower citizen suit cause of action, apparently subject to prudential limitations not relevant under the ESA, thus contradicts legislative history, is contrary to the historical context created by the Court's own standing discussions, and contradicts both the Court's own construction of standing under CWA itself and apparently uniform lower court case law. ${ }^{47}$ In short, had the Court engaged in a more rigorous contextual analysis, it should have found that, despite slightly different CWA language, the referent CWA provision means exactly what the Bennett Court interpreted the ESA provision to mean. ${ }^{48}$

While the legislative history, historical context, and judicial precedents surrounding the other statutory referents in Bennett are more limited than those related to the CWA, they too overwhelmingly contradict the Bennett opinion's implication. For example, the Surface Mining Control and Reclamation Act ("SMCRA") contains a citizen suit provision enacted in 1977 that contains the same language as the

CWA citizen suit provision based on Morton and its injury-in-fact test); United States v. Hooker Chems. \&: Plastics Corp., 540 F. Supp. 1067, 1080-81 (W.D.N.Y. 1982) (holding that plaintiff intervenors met the definition of "citizen" for CWA standing purposes because they met the Morton requirement of injury-in-fact); Michigan v. City of Allen Park, 501 F. Supp. 1007, 1013 (E.D. Mich. 1980) (finding that citizens and construction companies had standing under CWA citizen suit provision based on the requirements of Morton); J.E. Brenneman Co. v. Schramm, 473 F. Supp. 1316, 1320 (E.D. Pa. 1979) (finding that plaintiff contractor lacked standing under CWA citizen suit provision because it did not meet Morton injury-in-fact requirement); Montgomery Envtl. Coalition v. Fri, 366 F. Supp. 261, 264 (D.D.C. 1973) (holding that plaintiff community groups had standing under CWA citizen suit provision based on analysis under the Morton rubric); Brown v. Ruckelshaus, 364 F. Supp. 258, 264 (C.D. Cal. 1973) (denying standing based on lack of plaintiffs' establishment of injury-in-fact). Most scholars addressing the issue have concluded that in CWA cases, the injury-in-fact test is the threshold standing requirement and that prudential limits do not apply. See, e.g.,

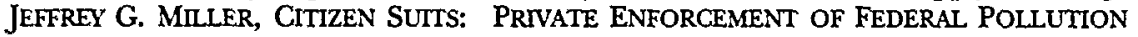
CONTROL LAWS 22 (1987) (stating that the Supreme Court has interpreted standing under the CWA by applying the Morton standard); Robert B. June, The Structure of Standing Requirements for Citizen Suits and the Scope of Congressional Power, 24 ENVTL. L. 761, 769 (1994) (articulating this view); Katherine B. Steuer \& Robin L. Juni, Note, Court Access for Environmental Plaintiffs: Standing Doctrine in Lujan v. National Wildlife Federation, 15 HARV. ENVTL. L. REV. 187, 193 (1991) (same).

${ }^{47}$ See supra note 46 (citing cases contradicted by the Bennett decision's interpretation of citizen suit).

48 Furthermore, the Trafficante cause of action's conferral of standing to "any person who claims to have been injured by a discriminatory housing practice," Civil Rights Act of 1968,42 U.S.C. $\$ 810$ (a) (1968), was construed in that case to provide standing to the extent allowed by Article III. That language appears to be equally amenable to an interpretation that it too creates a limited "zone," but the Court somehow found this linguistic difference insignificant, while inexplicably holding in Bennett that the CWA's equally minor dissimilarity is important. For a discussion of Trafficante, see supra notes $27-29$ and accompanying text. 
CWA. SMCRA's legislative history reveals an intent that the provision "shall be construed to be coterminous with the broadest standing requirements enunciated by the U.S. Supreme Court." Historical context, in particular case law discussing the contours of citizen suit standing, largely tracks the case law discussing the CWA; no case then decided had ever interpreted language like that in the SMCRA to reveal a statutory intent to create prudential hurdles to standing. ${ }^{50}$ Most case law subsequent to SMCRA's enactment has focused on this citizen suit language as leaving only constitutional standing criteria as a hurdle for citizen suit plaintiffs. ${ }^{51}$ Though the other referent statutes provide less grist for the Court's conclusion or this Article's discussion, they similarly appear to have been cited based on little more than the Court's impressions. ${ }^{52}$

${ }^{49}$ H.R. REP. NO. 95-218, at 90 (1977), reprinted in 1977 U.S.C.C.A.N. 593, 626. In the bill's conference report, there is no indication of debate or contention regarding this provision or its reach. See H.R. CONF. REP. NO. 95-493, at 97 (1977), reprinted in 1977 U.S.C.C.A.N. 728, 729. In fact, critics of the bill were aware of the breadth of the citizen provision and criticized statutory language for that reason. See H.R. REP. NO. 95-218, at 193.

${ }^{50}$ See supra notes $44-46$ and accompanying text (discussing Sierra Club and postCWA enactment cases interpreting the Constitution to be the only standing hurdle relevant to CWA citizen suits).

${ }^{51}$ See, e.g., Nat'l Mining Ass'n v. United States Dep't of Interior, 70 F.3d 1345, 1349 (D.C. Cir. 1995) (discussing the need "to establish the "irreducible constitutional minimum of standing" (citations omitted)); Powder River Basin Res. Council v. Babbitt, 54 F.3d 1477, 1485 (10th Cir. 1995) (focusing upon only constitutional standing requirements); Whitney Benefits, Inc. v. United States, 752 F.2d 1554, 1558 (Fed. Cir. 1985) (stating that "[a]s the title 'citizen's suit' implies, the object of writing the provision was to assure access to the courts by 'private attorneys general' whose standing was as tenuous as the Supreme Court would permit," that is, as limited only by Article III). One court sees "zone" analysis as still relevant under SMCRA. See Nat'l Wildlife Fed'n v. Hodel, 839 F.2d 694, 704 n.7 (D.C. Cir. 1988).

${ }^{52}$ The Energy Supply and Environmental Coordination Act ("ESECA") used "suffering legal wrong" language, 15 U.S.C. $\$ 797(b)(5)$ (1994), but like the CWA and SMCRA, this 1974 enactment was drafted shortly after Sierra Club, and its chosen language comports with that case's standing approach as partially lifted from the Administrative Procedure Act. Little pre- or post-enactment debate or history sheds light on why this language was chosen, but, conversely, nothing in this language or history indicates an intent to limit standing. See, for example, the APA's general "right of review" provision, 5 U.S.C. $\$ 702$ (1994) (stating that "[a] person suffering legal wrong because of agency action, or adversely affected or aggrieved by agency action within the meaning of a relevant statute, is entitled to judicial review thereof") (emphasis added). For a discussion of opinions construing and distinguishing this and other APA language, see STEPHEN BREYER ET AL., ADMINISTRATTVE LAW AND REGULATORY POLICY 875, 881-82 (4th ed. 1999). The citizen suit provision in the Ocean Thermal Conversion Act ("OTECA"), enacted in 1980, also appears to closely track constitutional standing minima. See 42 U.S.C. $\$ 9124$ (a) (1994) (stating that "any person having a valid legal interest which is or may be adversely affected may commence a civil action ... whenever 


\section{West Virginia University Hospitals v. Casey: Deliberate Historical Disregard}

Justice Scalia's opinion for a divided Court in West Virginia Hospitals v. Casey ${ }^{53}$ reveals once again the one-Congress fiction in action. Perhaps even more interestingly, the Court in Casey acknowledged its decision to ignore historical materials contradicting the conclusions it reached by reference to text alone. ${ }^{5 *}$ In its conclusions and in its methodology, the Court rejected the more context-based opinion of Judge Posner in Friedrich v. City of Chicago. ${ }^{55}$ The issue in Casey was whether a prevailing civil rights litigant was entitled to recover expert witness fees as part of the attorney's fees explicitly made awardable

such action constitutes a case or controversy"). The limited legislative history indicates only that this section follows "the standard procedures for civil procedures and judicial review." S. REP. NO. 96-721, at 9 (1980), reprinted in 1980 U.S.C.C.A.N. 2407, 2415. There is no reported case law construing this somewhat obscure provision. The other statutes referenced by Justice Scalia in Bennett-a 1968 agricultural law, a 1916 antidumping law, and a 1906 gold and silver stamping law to which a citizen suit provision was added in 1970, do appear to reveal a limited number of citizens who were granted a cause of action, but in language and in statutory contexts that may reflect more who would be likely to want to sue than an intent to create prudential barriers to suits. Compare The Agricultural Fair Practices Act of 1968, 7 U.S.C. $\$ 2305$ (c) (1994) (defining citizen as "any person injured in his business or property"), and The Anti-Dumping Act of 1916, 15 U.S.C. $\$ 72$ (1994) (same), with The National Gold and Silver Stamping Act of 1906, 15 U.S.C. $\$ 298$ (b) (1994) (defining citizen as "any competitor, customer, or competitor of a customer of any person" in violation of the Act).

499 U.S. 83 (1991).

${ }^{3}$ Id. at 97-101. For a pointed and thorough critique of Casey and a skeptical assessment of whether an interest in textualism actually motivated Justice Scalia to reach his conclusions, as well as a more thorough investigation into the historical context of Casey, see T. Alexander Aleinikoff \& Theodore M. Shaw, The Costs of Incoherence: A Comment on Plain Meaning, West Virginia University Hospitals, Inc. v. Casey, and Due Process of Statutory Interpretation, 45 VAND. L. REV. 687 (1992).

55 888 F.2d 511 (7th Cir. 1989), vacated, 499 U.S. 933 (1991) (vacated in light of Casey). Judge Posner's opinion for a unanimous Seventh Circuit declined to engage in interstatutory textual comparison of the type criticized in this Article as "the oneCongress fiction." In addition to pointing out the unrealistic assumptions of omniscience implied by drawing inferences from such textual comparisons, $888 \mathrm{~F} .2 \mathrm{~d}$ at 517 , Posner responded to litigant arguments that "repeals by implication are disfavored" in terms akin to the logic suggested in this Article: such an interpretive approach "protects some old statutes from, as it were, inadvertent destruction, but it threatens to impale new statutes on the concealed stakes planted by old ones," id. at $\mathbf{5 1 6}$. He examined the history of the primary statute at issue and relied on the logic and language of his opinion in Edwards v. United States, 814 F.2d 486, 488 (7th Cir. 1987), to reject arguments against allowing a shifting of expert expenses. An additional reason he offered for rejecting text-to-text comparisons is stated in Edwards: "forgotten statutes lurking in the statute book, plus remembered statutes that have acquired non-obvious meanings through a process of judicial or regulatory interpretation, will make the body of unrepealed statutes a minefield for [a] new law." Id. at 488 (cited in Friedrich, 888 F.2d at 516). 
under 42 U.S.C. $\$ 1988$ (1976). ${ }^{56} \quad$ The Court held that prevailing plaintiffs could not recover such expenses. ${ }^{57}$

The statutory provisions at issue in Casey concededly did not contain explicit language that courts should award expert expenses to prevailing plaintiffs. To buttress the majority's conclusion that this omission was significant, Justice Scalia contrasted $\S 1988$ and its omission of any reference to expert fee shifting with numerous other statutes from times before and after $\S 1988$ 's enactment in 1976. These statutory referents contain language explicitly authorizing awards of expert-related expenses to prevailing parties. ${ }^{58}$ In addition, the general statute setting forth when and what a "judge or clerk of any court may tax as costs," also lacks any general authorization for courts to award expert expenses except to the extent that experts might be entitled to nominal witness "attendance fees." ${ }^{59}$ The Court then cited Crawford Fitting Co. v. J.T. Gibbons, a 1987 case in which it had, in the words of the Casey opinion, articulated a "clear statement" rule that "these provisions define the full extent of a federal court's power to shift litigation costs absent express statutory authority to go further."

In support of his conclusion, Justice Scalia referred to a huge number of statutes that explicitly allow the award of expert expenses. He gave little attention, however, to what Professors Aleinikoff and Shaw have called the "vertical critique" of a law. In contrast to a "horizontal critique" that focuses on comparisons to other bodies of law, a "vertical critique" focuses on the history of a particular statute. ${ }^{61}$

${ }^{56}$ Both before and after Casey, $\$ 1988$ was subject to legislative amendments, including a post-decision amendment that in part undid the effect of Casey. See Aleinikoff \& Shaw, supra note 54, at 697-98 (citing and discussing the effect of The Civil Rights Act of 1991, § 113, Pub. L. No. 102-166, 105 Stat. 1071).

${ }^{57}$ Casey, 499 U.S. at 102.

${ }^{58}$ See id. at 88-89 \& n.4 (identifying "[a]t least 34 statutes" that "explicitly shift attorney's fees and expert witness fees").

${ }_{59} 28$ U.S.C. $\$ 1821$ (b) (1994), discussed in Casey, 499 U.S. at 86-87.

${ }^{60}$ Casey, 499 U.S. at 86 (citing Crawford Fitting Co. v. J.T. Gibbons, Inc., 482 U.S. $437(1987))$.

61 See Aleinikoff \& Shaw, supra note 54, at 697 ("[T] he Court's opinion in Casey is subject to ... a 'vertical' critique (that it ignores the easy-to-read history of Section 1988)."). Aleinikoff and Shaw criticize the absence of a "horizontal critique" focused on how Congress generally has dealt with expert expense awards in other civil rights laws. Id. ("[T] he Court's opinion in Casey is [also] subject to a ... 'horizontal' critique (that it is simply not plausible that Congress would award expert fees in other areas of the law but intentionally deny them in civil rights cases covered by Section 1988)."). For a similar distinction between horizontal and vertical critiques, see Eskridge, supra note 9, at 678-79 (employing these terms in criticizing the statutory interpretation of Justice Scalia); Zeppos, Justice Scalia's Textualism, supra note 9, at 1615, 1620-22 (using 
Most significantly, as argued in Justice Stevens's dissent, legislative history provided strong evidence that ran counter to Justice Scalia's inferences. The legislative history, as well as abundant case law precedents, revealed a concern for making civil rights plaintiffs whole and thereby removing financial deterrents to the initiation of such litigation. ${ }^{62}$ Legislative history also indicated that the 1976 version of $\$ 1988$ was intended by at least some legislators to restore the law to its state prior to the Court's 1975 ruling in Alyeska Pipeline $v$. Wilderness Society. ${ }^{63}$ There the Court rejected what Justice Scalia conceded was the practice of "many courts": "award[ing] expert fees and attorney's fees in certain circumstances pursuant to their equitable discretion." Moreover, in Missouri $v$. Jenkins, ${ }^{65}$ a 1989 case regarding the very same statute but in the context of a claim for recovery of time expended by paralegals and law clerks, the Court construed the statute to allow such awards despite the absence of explicit authorizing language. ${ }^{66}$

Justice Scalia explained his conclusion that Jenkins did not compel a similar conclusion in Casey by pointing out that unlike expert expense provisions that appear in many statutes, the Court did "not know of a single statute that shifts clerk or paralegal fees separately."

similarly the concept of "horizontal" statutory analysis).

${ }^{102}$ See Casey, 499 U.S. at 108-11 (Stevens, J., dissenting). Whether this evidence of legislator and judicial concern, or perhaps intent, should appropriately be given interpretive weight is another question and is explored more in the parts below. For a concise and powerful argument for why "legislative intent" is an oxymoron, see Kenneth A. Shepsle, Congress is a "They," Not an "It": Legislative Intent as Oxymoron, 12 INT'L REV. OF L. \& ECON. 239 (1992) (building upon Arrow's Theorem to explore the impossibility of there ever being an intent of a collective and procedurally complex body such as Congress).

421 U.S. 240 (1975).

it Casey, 499 U.S. at 97 (citing Alyeska Pipeline, 421 U.S. at 269); see also 499 U.S. at 108-11 (Stevens, J. dissenting) (reviewing legislative history reflecting legislators' and committees' intent to undo the effect of $A$ lyeska); Aleinikoff \& Shaw, supra note 54, at 69498 (discussing the impact of Alyeska and the legislative response to the decision).

${ }^{65} 491$ U.S. 274 (1989) (holding that the fees for paralegals and clerks should be awarded based on their market value).

${ }^{60}$ For a particularly insightful discussion of the same issue as was before the Casey Court, including a dialogue on the implication of Jenkins, previous assumptions about courts' equitable powers to shift various sorts of costs and the implications of the legislative response to Alyeska, see Friedrich $v$. City of Chicago, 888 F.2d 511 (7th Cir. 1989) (Posner, J.), discussed supra note 55. Judge Posner also commented critically and at length about "plain meaning" interpretive approaches and distinguished problems with reliance on legislative history, particularly individuals' statements, contrasted with the ongoing value of attention to historical context. Id. at 513-19.

4799 U.S. at 99 . Interestingly, although neither the Casey majority nor the dissent note this fact, the record of Jenkins reveals that in that case the fee and cost award of the district court and court of appeals included expert witness fees despite Missouri's contesting of such an award. See Aleinikoff \& Shaw, supra note 54, at 696 (discussing 
Responding to the dissents' criticisms of his opinion for failing to examine legislative history and the common pre-Alyeska practice of awarding expert expenses to civil rights plaintiffs, Justice Scalia responded that "Congress could easily have shifted 'attorney's fees and expert witness fees,' or 'reasonable litigation expenses,' as it did in contemporaneous statutes; it chose instead to enact more restrictive language, and we are bound by that restriction."

In contrast to most other Supreme Court cases in which the oneCongress fiction has been used without explanation, Justice Scalia set forth a brief explanation for his interstatutory references, but in this case at least using the plural term "Congresses." He stated that the Court construes a statutory term "to contain that permissible meaning which fits most logically and comfortably into the body of both previously and subsequently enacted law." ${ }^{70}$ The Court's task, in Justice Scalia's view, is "to make sense rather than nonsense out of the corpus juris. But where, as here, the meaning of the term prevents such accommodation, it is not our function to eliminate clearly expressed inconsistency of policy and to treat alike subjects that different Congresses have chosen to treat differently." ${ }^{71}$ As he has in many cases, Justice Scalia refused to consider legislative history or examination of historical context, instead relying on "the statutory text adopted by both Houses of Congress and submitted to the President."72 Despite this brief explanation, Justice Scalia provided no real explanation for his interpretive conclusion that the absence of a provision allowing or encouraging expert expense awards is equivalent to a prohibition on such an award, even where the primary statute explicitly authorizes fee shifting. ${ }^{73}$

this feature of Jenkins by Agyei v. Missouri, 838 F.2d 260, 266 (8th Cir. 1988)).

${ }^{68}$ Casey, 499 U.S. at 99.

${ }^{69}$ Id. at 101 .

7d. at 100 (citation omitted).

${ }^{71} I d$. at 101 . He continued by stating that the "facile attribution of congressional 'forgetfulness' cannot justify such a usurpation.... In such circumstances, the attribution of forgetfulness rests in reality upon the judge's assessment that the later statute contains the better disposition." Id.

${ }^{72}$ Id. at 98. In this discussion, Justice Scalia's rhetoric closely tracks the writings of Judge Frank Easterbrook. See, e.g., Continental Can Co. v. Chicago Truck Drivers, Helpers \& Warehouse Workers Union (Independent) Pension Fund, 916 F.2d 1154, 1157 (7th Cir. 1990) ("The text of the statute, and not the private intent of the legislators, is the law."); Frank H. Easterbrook, Statutes' Domains, 50 U. CHI. L. REV. 533, 54449 (1983) (stating that the domain of the statute should be restricted to cases expressly resolved in the legislative process). These writings are discussed in Shepsle, supra note 62 , at 253 n.24).

${ }_{73}$ Justice Scalia undoubtedly placed great weight upon the background "American 
Casey thus offers a partial explanation for the one-Congress fiction interpretive methodology, namely the Court's obligation to make sense of the corpus juris. The majority's failure to afford significant weight to legislative history also reveals the now familiar shunning of legislator statements and committee report discussions, even if they directly contradict a text-based conclusion. Furthermore, as in Bennett, the Casey decision appears to disregard different kinds of statutory history that are arguably not subject to manipulation, namely pre-enactment practices of courts, presumptions in related bodies of case, regulatory, or statutory law (here civil rights cases and laws), and the chronology of court decisions and statutory responses. ${ }^{74}$ Instead, the Court favored simpler text-to-text comparisons. It devoted no attention to the particular pre-enactment contexts of the many referent statutes cited by Justice Scalia. Different statutory drafting strategies in different fields and different pre-enactment judicial practices were neither examined nor considered.

To the Casey dissenters, as most thoroughly articulated by Justice Stevens, the Court should have looked to the prevailing practice of courts in civil rights cases, the legislative response to Alyeska, and legislator and committee statements. It also should have cited materials reflecting the 1976 amendment of $\S 1988$ as a response to Alyeska, the general purpose of $\$ 1988$ and similar civil rights laws, and the related policy of making civil rights plaintiffs whole. For Justice Stevens, rather than examining other statutes in unrelated fields, and reading an omission as a prohibition, the Court should have focused on "the way in which the Court has interpreted the text of this statute in the past, as well as this statute's legislative history." ${ }^{\text {"5 }}$ He also looked to policy-based considerations and the majority's creation of an odd incentive for over-billing by attorneys who now could not rely on experts and recover associated expenses. ${ }^{76}$

rule," which presumptively disfavors fee shifting, but he did not explain why such a rule should still prevail when a statute contains an explicit authorization of attorney's fees and cost shifting but leaves expert expenses unaddressed. He construed this omission as equivalent to an intentional preclusion, in effect making the "American rule" fully effective for other litigation expenses whether a statute omits any reference to fee shifting or authorizes shifting of attorney's fees and costs. See 499 U.S. at 99.

${ }^{74}$ As shown in Part $\mathrm{N}$, infra, the Court does at times engage in interstatutory referencing with attention to more than mere text.

795 U.S. at 103 (Stevens, J., dissenting).

it See id. at 106-08 ("If attorneys were forced to do the work that paralegals could just as easily perform under the supervision of an attorney,... then "it would not be surprising to see a greater amount of such work performed by attorneys themselves, thus increasing the overall cost of litigation." (quoting Missouri v. Jenkins, 491 U.S. 274,288 n.10 (1989))). 


\section{FDA v. Brown $\mathcal{E}^{2}$ Williamson Tobacco Corp.: Devaluing Text and Privileging Post-Enactment Legislative Activity}

The Court's recent opinion in FDA v. Brown E' Williamson Tobacco Corp. ${ }^{77}$ contains arguments and logic that fall squarely within this Article's discussion of the one-Congress fiction. In other respects, however, the opinion and the case's posture make it distinguishable from most examples of this interpretive methodology. In reaching the conclusion that the FDA lacked authority to regulate cigarettes and other tobacco products, Justice O'Connor analyzed numerous statutory enactments regarding tobacco that post-date the primary enabling act at issue, examined numerous forms of legislative history, and gave reduced attention to the key statute's text. The identity of the regulatory target of the numerous statutes compared by Justice O'Connor makes the FDA tobacco case distinguishable from cases like Bennett and Casey in which diverse, unrelated statutes regulating different targets were compared based on similarities in their language or regulatory mechanisms. ${ }^{78}$ Nevertheless, the Brown $\mathcal{E}^{2}$ Williamson majority opinion contains an essential strain of logic that looks at Congress as a unitary, unchanging principal revisiting its own work and thereby shedding light on the meaning of the much earlier law relied on by the FDA. Both for its similarities and dissimilarities to other oneCongress fiction cases, this case provides material that illuminates the present discussion.

The FDA's 1996 assertion of authority to regulate tobacco was based on its construction of the Food, Drug and Cosmetic Act ("FDCA"), as enacted in 1938 . $^{79}$ The agency relied heavily on early

77 120 S. C. 1291 (2000).

${ }^{78}$ A further distinction is the FDA tobacco opinion's tendency not to parse particular linguistic formulations in compared statutes, but to focus on general regulatory domains and strategies evident in tobacco laws enacted since 1938.

${ }^{79}$ Pub. L. No. 52-675, 52 Stat. 1040 (1938) (codified as amended at 21 U.S.C. $\$ \S$ 301-95 (1994)). The FDA's assertion of regulatory authority is found at 61 Fed. Reg. $44619-5318$ (1996). For critiques of the 1996 FDA assertion of authority to regulate tobacco products, see Richard A. Merrill, The FDA May Not Regulate Tobacco Products as "Drugs" or as "Medical Devices, " 47 DUKE L.J. 1071, 1093 (1998) (featuring arguments by a law professor who also served as tobacco counsel, and concluding that "Congress did not give the FDA jurisdiction over tobacco products.... And on the several occasions when Congress considered its options, it made conscious decisions to deal with the subject in other ways, through different instruments"), and Lars Noah \& Barbara A. Noah, Nicotine Withdrawal: Assessing the FDA's Effort to Regulate Tobacco Products, 48 ALA. L. REV. 1, 7 (1996) ("[T] he FDA regulations exceed the Agency's delegated authority."). But see Cass R. Sunstein, Is Tobacco a Drug? Administrative Agencies as Common Law Courts, 47 DUKE L.J. 1013, 1019 (1998) ("[R] eviewing courts should uphold the regulation, principally by reference to the appropriate role of contemporary administrative 
1990s revelations that tobacco companies were knowingly using cigarettes as a means to deliver "'a day's supply of nicotine.", Subsequent to 1938 , Congress had enacted numerous statutes that regulated various aspects of the tobacco industry and tobacco products, while the FDA declined to regulate tobacco products. In Brown $\mathcal{E}^{2}$ Williamson, the tobacco industry challengers, the FDA, other partisans, and the majority and dissenting Supreme Court Justices differed in their assessments of what the 1938 statute authorized, the implications of the FDA's decision not to assert regulatory authority over tobacco products, and the significance of the post- 1938 legislative activity.

Justice O'Connor's opinion, joined without qualification by textualist Justices Scalia and Thomas (as well as by Chief Justice Rehnquist and Justice Kennedy), roamed widely in looking at legislative materials viewed as relevant to the question of the FDA's authority. Far from a text-limited analysis, this opinion delved into the very forms of legislative history usually shunned by textualists, including quotations of witnesses at legislative hearings, individual legislator and regulator statements, and histories of both enacted and unenacted bills that post-dated the 1938 law on which the FDA based its jurisdiction. ${ }^{81}$ Furthermore, the majority reached a conclusion contrary to that most easily justified based on textual analysis. ${ }^{82}$ Based on its evaluation of the FDCA text, an array of legislative materials, and a limited parsing of interrelated statutory texts, the majority determined that Congress did not grant the FDA authority to regulate tobacco products. ${ }^{83}$ The

agencies.").

"11' $120 \mathrm{~S}$. Ct. at 1321-22 (Breyer, J., dissenting) (citations omitted); see also id. at 1320-22 (quoting rarious scientists' statements regarding nicotine's effects and the use of cigarettes as a means to deliver nicotine and satisfy consumers' desire for "drug action").

${ }^{11}$ See id. at 1300-13 (considering, for example, the 1964 testimony of the Surgeon General that the Department of Health, Education and Welfare lacked the authority to label cigarette packages under the existing law governing the FDA). The case is unusual in that the textualists silently joined a majority opinion that went far beyond textbased analysis to rely on diverse forms of legislative history created over several decades.

"2: The dissent criticized the majority for failing to give adequate weight to that which the majority "nowhere denies": that the statute's language and purpose support the FDA assertion of jurisdiction over tobacco. Id. at 1316-17, 1319-21 (Breyer, J., dissenting).

${ }^{3}$ The Court's analysis of the FDCA itself is unusual in its structure and a bit elusive in its logic. As the dissent rightly pointed out, the majority nowhere denied that the FDCA's text by its terms conferred on the FDA power to act as it did (although without mentioning tobacco in its text). Id. at 1316 (Breyer, J., dissenting). Instead, the majority's logic was that the FDA lacks its asserted power because if tobacco could be regulated as a "drug," "device," or "combination product," then the FDCA would 
Court also added what appears to be a new context for application of the clear statement doctrine: "we are confident that Congress could not have intended to delegate a decision of such economic and political significance to an agency in so cryptic a fashion."

The one-Congress fiction logic pervades the opinion, with Justice O'Connor repeatedly referring to how Congress subsequent to 1938 "spoke[]," revealing and confirming through subsequent legislative activities that the FDA lacked its asserted regulatory authority. ${ }^{85}$ These activities and enactments shed light, according to the majority, on whether the 1938 statute actually reflected a congressional grant of FDA authority to regulate tobacco. As the Court stated, the "collective premise" of numerous post- 1938 tobacco laws "is that cigarettes and smokeless tobacco will continue to be sold in the United States." The Court therefore concluded that the 1938 law, plus seven subsequent tobacco-regulating laws, reveal that "Congress has created a distinct regulatory scheme to address the problem of tobacco and health, and that scheme, as presently constructed, precludes any role for the FDA. ${ }^{87}$

These conclusions are supported by both persuasive and unconvincing logic. The majority's strongest argument is that the FDA's 1996 assertion of power to regulate tobacco advertising contradicted the implications of post-1938 laws. As the majority noted, "[t]he regulation of product labeling . . is an integral aspect of the FDCA," post-1938 tobacco laws prohibited any cigarette packaging statements other than that required by the Federal Cigarette Labeling and Adver-

require the FDA to ban tobacco products, or at least cigarettes. Id. at 1301-03. Rather than holding that the FDA's error was therefore in its choice of regulatory or remedial option, the majority concluded that post-enactment history, including both subsequent laws and a wide variety of legislative and regulatory statements of individuals, revealed a legisiative assumption that tobacco products would continue to be sold. Id. at 130306. Therefore, under the majority's logic, the FDA could not have the jurisdiction over tobacco that it claimed. Id. at 1306. The dissent argued that if the majority was correct about the FDA's jurisdiction, then the Court should merely have faulted the FDA's chosen limited remedy and instead have required the banning of tobacco products. Id. at 1322-23 (Breyer, J., dissenting). The dissent also argued, however, that the FDA had remedial discretion and a broader set of regulatory options than concluded by the majority. Id. at 1322-26 (Breyer, J., dissenting).

${ }^{84} \mathrm{Id}$. at 1315 .

${ }^{85}$ See, e.g., id. at 1301 ("Congress has directly spoken to the issue here and precluded the FDA's jurisdiction to regulate tobacco products.").

${ }_{86}^{8}$ Id. at 1304.
${ }_{88}$ Id. at 1307.
${ }^{8 d}$. at 1309. 
tising Act ("FCLAA"). The FCLAA and other statutes regulating tobacco revealed, according to the majority, a Congress "reserving exclusive control over both subjects to itself." Congress's repeated forays into tobacco regulation gave the majority a tenable basis for concluding, as several legislators had asserted in legislative history quoted by the Court, that "further regulation in this . . complex area must be reserved for specific Congressional action." soundly saw itself as unavoidably thrust into a dispute where it had to look at how various laws pertaining to tobacco and FDA authority interrelated: "the meaning of one statute may be affected by other Acts, particularly where Congress has spoken subsequently and more specifically to the topic at hand. ${ }^{, 2}$

The Court also, however, engaged in several questionable interpretive approaches. The Court's heavy emphasis on the FDA's longtime declination to regulate tobacco products is of questionable logic. The majority read FDA statements declining to regulate tobacco as reflecting an FDA belief that it could never assert such authority, but as the dissent argued, the FDA's official regulatory acts (versus scattered statements by individual FDA regulators) revealed an agency that for years either lacked the political will or factual basis to regulate tobacco products. As the FDA asserted in 1995, new evidence of internal industry acknowledgments of nicotine's effects and discussions of cigarettes as a means to deliver nicotine constituted new information that, in its view, sufficed to give the FDA the factual basis to assert jurisdiction that it had previously lacked. ${ }^{93}$ Based primarily on textual analysis

${ }^{\times 9}$ Pub. L. 89-92, 79 Stat. 282 (1965) (codified as amended at 15 U.S.C. $\$ \$ 1331-41$ (1994)).

"*1 Brown $\$$ Williamson, 120 S. Ct. at 1309.

IId. at 1310 (quoting S. REP. No. 94-251, at 43 (1975) (delineating the views of Sens. Hartke, Hollings, Ford, Stevens, and Beall)). The Court also quoted an individual legislator's floor statement about a bill's relationship to a controversial district court opinion, see id. ("the 'legislation, in effect, reverse[d]' the District Court's decision," (quoting the acknowledgement of Sen. Moss, 121 CONG. REC. 23,563 (1975))), as well as a letter sent in 1980 by the FDA Commissioner Goyan, see id. ("[T] he FDA later observed that the episode was 'particularly' 'indicative of the policy of Congress to limit the regulatory authority over cigarettes by Federal Agencies." (quoting Letter from Commissioner Goyan, FDA, to Executive Director Banzhaf, Action on Smoking and Health (Nov. 25, 1980)) (citation omitted)).

II Id. at 1301 (citing United States v. Estate of Romani, 523 U.S. 517, 530-31 (1998); United States v. Fausto, 484 U.S. 439, 453 (1988)).

" For a review of this new evidence, see Sunstein, supra note 79, at 1025-26, discussing revelations concerning the number of deaths caused by tobacco, ways in which "tobacco affects the structure or function of the body," and when knowledge of these effects was gained. For a similar discussion, see Brown $\mathcal{E}$ Williamson, $120 \mathrm{~S}$. Ct. at 1321- 
and careful parsing of the FDA's statements regarding its power to regulate tobacco, coupled with heavy emphasis on the facts revealed in the 1990s about tobacco industry knowledge and research regarding nicotine, the dissenters contended that the FDA had an adequate basis for its decision to regulate tobacco. ${ }^{94}$

The majority's and dissenters' careful examinations of a wide variety of legislative sources in determining whether the FDA actually possessed its asserted authority constitutes a welcome contrast to oneCongress fiction cases, such as Casey, where the Court utterly failed or even refused to examine the historical context of a disputed statutory provision. ${ }^{95}$ As this Article advocates, all members of the Court in Brown $\mathcal{E}$ Williamson manifested comfort with viewing statutory enactments as the product of a complex ongoing political conversation among the legislative branch, agency officials, the courts, and regulatory partisans. One might question the Court's self-avowed textualists for their possibly ends-oriented willingness to abandon their methodological purity to reach a result contrary to that called for by more text-dependent modes of interpretation. Such general agreement among the Justices on recourse to a wide array of sources of authority, however, is unusual with the Court's current personnel and deserves praise. How the majority used these sources of authority, however, deserves criticism even if the Court's conclusion is a close question.

The majority's reliance on the idea that there is one Congress is once again questionable. The 1938 law relied upon by the FDA in 1996 was, in Justice O'Connor's view, aimed at more routine FDA targets, with little attention to, or expectation that, consumer tobacco products would be regulated by the FDA. ${ }^{96}$ The language of that statute, however, appears well suited to the agency's assertion of jurisdiction, providing the FDA with authority to regulate "articles (other than food) intended to affect the structure or any function of the body. ${ }^{97}$ The majority missteps in taking scattered post-1938 legislator and regulator statements about the FDA's earlier decisions not to assert jurisdiction as reflecting a view that it could never do so, or as evidencing an agreement between the FDA and Congress that the agency could not do so. To take isolated statements by various regulatory and

22 (Breyer, J., dissenting).

${ }_{95}$ Brown E् Williamson, 120 S. Ct. at 1316-31 (Breyer, J., dissenting).

${ }^{95}$ See supra notes 53-76 and accompanying text.

${ }^{96}$ See Brown E' Williamson, $120 \mathrm{~S}$. Ct. at 1316 ("Reading the FDCA as a whole ... it is plain that Congress has not given the FDA the authority that it seeks to exercise here.").

${ }^{97} 21$ U.S.C. $\$ 321(\mathrm{~g})(1)(\mathrm{C})$ (1994). 
legislative stakeholders, especially regarding proposed post-1938 laws, as revealing what the 1938 law means remains an illogical use of the one-Congress fiction and in fact closely resembles dynamic modes of statutory interpretation. ${ }^{98}$ In addition, the majority's combining of interstatutory cross-referencing, as is the essence of the one-Congress fiction, with recourse to a wide array of legislative history and stakeholder comments about a wide array of laws, proposed laws, and regulatory activity, adds up to a remarkably manipulable set of data for interpretation. That individual regulators and legislators over the years would repeatedly voice positions in line with the tobacco industry's preference for no FDA regulation is unsurprising. What is astounding is that the Court, including the Court's purported textualists, would quote and rely so heavily upon such statements while giving little weight to the key enabling act text.

As further discussed below, debate surrounding these newer laws and other proposed bills and regulations should not have been relied upon to construe the FDA's authority under the 1938 law. Greater attention instead should have been paid to pre-1938 historical context, coupled with attention to how actually-enacted tobacco statutes interrelate. $^{.4}$ While the case presents what was undoubtedly a close question, the strength of the dissent's arguments becomes apparent if one omits from consideration the many post-enactment, nonstatutory statements regarding tobacco regulation, and instead gives paramount weight to the 1938 Act itself coupled with greater deference to the FDA's conclusions about the significance of 1990s revelations. Attention to historical context makes sense, but recourse to self-referential statements of legislative participants about what they think a law or

For a comparison of the one-Congress fiction and dynamic statutory interpretation approaches, see infra Part III.B.4. The dissent looked at the abundant post-1938 history as being consistent with a different conclusion, namely that such activity reflected care not to disturb the 1938 legal authority, with only one express congressional enactment specifically referring to the $1938 \mathrm{FDCA}$ authority. That statute, The FDA Modernization Act of 1997, explicitly disclaimed any efforts to constrain or deny FDA tobacco authority. See 21 U.S.C. $\$ 321$ note (Supp. III 1997) (Regulation of Tobacco) (stating that "[n]othing in this Act ... shall be construed to affect the question of whether the [FDA] has any authority to regulate any tobacco product"), quoted in Brown $\mathcal{E}$ Uthliamsan, 120 S. Ct. at 1316, 1327 (Breyer, J., dissenting).

${ }^{\prime x}$ The majority spent pages analyzing post-1938 regulatory statements, statutes, and bills, but deroted only one paragraph to the 1938 law's enactment context. See Broum \& Iriliamson, $120 \mathrm{~S}$. Ct at 1308 . The dissent, in contrast, looked in greater detail at the 1938 Act's "vertical history." Id. at 1317-19 (Breyer, J., dissenting) (examining the Act's pre-enactment history, the Court's construction of that law, and general understandings prevalent in legislation from around 1938 that granted broad authority to administrative agencies). 
regulation should mean remains a problematic source for interpretive guidance. $^{100}$

\section{Other Supreme Court Examples}

Bennett, Casey, and Brown $\mathcal{E}^{2}$ Williamson are far from the sole examples of judicial use of the one-Congress fiction. For example, in Gebser v. Lago Vista Independent School District, Justice O'Connor wrote the majority opinion in a case that divided the Court five to four. ${ }^{101}$ As in Brown $\mathcal{E}^{2}$ Williamson, she gave significant weight to a referent statute that post-dated the primary statute at issue. Gebser concerned the prerequisites for an implied private cause of action for damages under Title IX, a 1972 civil rights statute that links the receipt of federal dollars to a prohibition on sex discrimination. To justify its conclusion that such a private action could not be brought absent deliberate indifference of the defendant school district to a teacher's sexual harassment of a student and actual notice of such harassment, the Court compared Title IX with provisions of Title VII enacted in $1991 .^{102}$ Title VII's 1991 amendment provides a private cause of action for damages, but limits the amount of damages allowable. ${ }^{103}$ Title IX, in contrast, contains no explicit private cause of action. However, in Cannon v. University of Chicago ${ }^{104}$ and Franklin v. Gwinnett County Public Schools, ${ }^{105}$ decided in 1979 and 1992 respectively, the Court had first implied a Title IX private cause of action although the statute contained only textual reference to administrative enforcement and then, in the later case, concluded that the implied private cause of action includes a right to damages. ${ }^{106}$ Gebser, in the words of Justice O'Connor, set out

${ }^{100}$ Justice Breyer's dissent offers a strong rebuttal of the majority's view that the FDA could not assert jurisdiction over tobacco because the FDCA would appear to mandate FDA banning of cigarettes. The majority states that such a conclusion is untenable. Id. at 1301-06, 1314. Justice Breyer countered that the FDA should be found to have discretion in the exercise of its remedial power, but also suggested that if the majority's statutory reading were correct, then the FDA erred not in asserting jurisdiction, but in failing to ban cigarettes. Id. at 1322-23 (Breyer, J., dissenting).

${ }^{101} 524$ U.S. 274 (1998).

$102 \mathrm{Id}$. at $283-87$.

${ }^{103}$ See id. at 283 ("Title VII contains an express cause of action, ... . and specifically provides for relief in the form of monetary damages. .. Congress therefore has directly addressed the subject of damages relief under Title VII and has set out the particular situations in which damages are available as well as the maximum amounts recoverable.").

${ }^{104} 441$ U.S. 677 (1979).

${ }^{105} 503$ U.S. 60 (1992).

${ }^{106}$ See Gebser, 524 U.S. at 281-84 (describing the Cannon and Franklin holdings). 
to articulate "the contours of that liability."

The interstatutory cross-referencing in Gebser arises in two portions of the majority's opinion, one of which appears to be critical to its conclusion. The substantially later-enacted Title VII private cause of action explicitly includes "any agent" under its definition of "employers" who may be liable for discriminatory acts. ${ }^{108}$ The Court noted that "Title IX contains no comparable reference to an educational institution's 'agents,' and so does not expressly call for application of agency principles." 109 This seemingly minor comparative observation later became central to the Court's conclusion that school districts should not be liable for their teachers' actions absent actual notice of such a problem to officials with authority to take corrective action. Had the Court not read the absence of the term "agent" as indicating that an agent's (here teacher's) acts should not be imputed to their principal (the school system), the case might have reached a different conclusion. The Court similarly explained its unwillingness to allow unlimited damages recoveries for Title IX plaintiffs by comparing Title VII's limited damages remedy with the language of Title IX:

Adopting petitioner's position would amount, then, to allowing unlimited recovery of damages under Title $\mathrm{LX}$ where Congress has not spoken on the subject of either the right or the remedy, and in the face of evidence that when Congress expressly considered both in Title VII it restricted the amount of damages available. ${ }^{110}$

In dissent, Justice Stevens criticized the interstatutory comparisons and instead argued that the focus should be on Title IX's own history, particularly what he argued should have been the dispositive effect of the two previous Supreme Court cases construing Title IX impliedly to authorize a private damages action. ${ }^{111}$ Justice Stevens also took issue with the majority regarding the relevance of Title VII's inclusion of "agents" within its definition of "employer." Rather than drawing an

"117 Id. at 281. Much of both the majority and dissenting opinions focus on how best to construe this implied cause of action, with particular disagreement regarding whether it was sound reasoning for the majority to give substantial weight to notice requirements of Title IX's administrative enforcement scheme to justify its conclusion that private damages suits could only be brought where an "official who ... has authority to address the alleged discrimination and to institute corrective measures ... has actual knowledge of [the] discrimination." Id. at 290.

InI Id. at 283.

line Id.

"II" Id. at 286.

${ }^{111}$ See id. at 294-96 (Stevens, J., dissenting) ("We should ... seek guidance from the text of the statute and settled legal principles rather than from our views about sound policy."). 
inference from the cross-statutory comparison of this isolated language, he considered Title IX's "focus on the protected class" as explaining the lack of the term "agent." $\mathrm{He}$ further examined the vertical history of the Title VII referent "agent" and observed that the Court itself in 1986 construed that language not as an expansion of liability for employers, but as "'evinc [ing] an intent to place some limits on the acts of employees for which employers under Title VII are to be held responsible." "113 Stevens further rejected the majority's "creative argument" about inferences to be drawn from the comparison of the damages remedies of Titles VII and IX, stating that such an interstatutory difference "does not have any bearing on when damages may be recovered from a defendant in a Title IX case." 114

In Amoco Production Co. v. Southern Ute Indian Tribe, ${ }^{115}$ Justice Kennedy relied heavily on the one-Congress fiction in explaining his construction of 1909 and 1910 laws to conclude that "surface patentees," not the Southern Ute Indian Tribe who owned coal rights, owned coalbed methane gas. The 1909 and 1910 Coal Land Acts left unaddressed who had rights to such coalbed gas. As might be expected, part of Justice Kennedy's opinion focused on what was understood regarding coal mining and gas recovery at the time these laws were passed. ${ }^{116}$ He concluded that Congress "chose not to reserve oil, natural gas, or any other known or potential energy resources."117 His use of the one-Congress fiction appears in the next paragraph where he further justified his statutory construction with reference to several subsequent statutory enactments, ultimately concluding that " $[w]$ hen Congress wanted to reserve gas rights . . . it did so in explicit terms."118 No other Justice questioned the appropriateness of this interstatutory comparison.

The one-Congress fiction interpretive technique thus not only appears with frequency in the Court's opinions, but also has at times been critically important to the result reached. The Court has seldom offered more than a cursory defense of this approach to statutory in-

${ }^{112}$ Id. at 299 n.9 (Stevens, J., dissenting).

${ }^{113} I d$. (Stevens, J., dissenting) (quoting Meritor Sav. Bank, FSB v. Vinson, 477 U.S. $57,72(1986))$.

${ }_{114} I d$. at 302 (Stevens, J., dissenting).

115 526 U.S. 865 (1999).

${ }^{116}$ See id. at 868-71 (discussing the passage of, and motivation behind, several acts related to the allocation of coal-rich tracts of land).

${ }_{117}$ Id. at 877 .

${ }^{118} I d$. 
terpretation. ${ }^{119}$ The following Parts offer a critique of this interpretive practice and use this critique to explore larger questions about the underpinnings and limitations of textualist modes of interpretation.

${ }^{114}$ In additional Supreme Court cases from recent years, the majority opinion or separately drafted concurrences or dissents reveal interstatutory referencing of the sort referred to in this Article as the one-Congress fiction. See, e.g., Meghris v. KFC Western, 516 U.S. 479, 485 (1996) (O'Connor, J.) (denying recovery of cleanup costs under the Resource Conservation and Recovery Act ("RCRA") because of explicit provision of such recovery in the later enacted Comprehensive Environmental Response Compensation, and Liability Act of 1980 ("CERCLA") that "demonstrated" Congress "knew how to provide for [such] recovery"); Babbitt v. Sweet Home Chapter of Cmtys. for a Greater Or., 515 U.S. 687, 717-20 (1995) (Scalia, J., dissenting) (disagreeing with the majority's construction of the term "harm" under the ESA and citing other statutes" use of the term to justify a contrary result); City of Chicago v. Envtl. Def. Fund, 511 U.S. 328, 337-38 (1994) (Scalia, J.) (confirming an interpretation of a provision in RCRA with reference to a provision in the Superfund Amendments and Reauthorization Act of 1986 and stating that "[w]e agree with respondents that this provision 'shows that Congress knew how to draft a waste stream exemption in RCRA when it wanted to" (quoting Brief for Respondents at 18)); Pierce v. Underwood, 487 U.S. 552, 564-67 (1988) (Scalia, J.) (construing Equal Access to Justice Act's phrase "substantially justified" in light of the APA's use of the term "substantial," dictionary usage, and the Federal Rules of Civil Procedure, but also briefly alluding to the legislative history and case exegesis of similar terms to buttress its conclusion); United States v. Fausto, 484 U.S. 439, 444-50 (1988) (Scalia, J.) (interpreting the Civil Service Reform Act's judicial review provision in light of several other laws, but also looking beyond mere text to legislative history and other evidence of the historical context of referent provisions); Wimberly v. Labor \& Indus. Relations Comm'n, 479 U.S. 511,517 (1987) (O'Connor, J.) (interpreting language in the Federal Unemployment Tax Act by turning to prior Court interpretations of similar language in veterans statutes); Metro. Life Ins. Co. v. Taylor, 481 U.S. 58, 65-66 (1987) (O'Connor, J.) (employing the Labor Management Relations Act ("LMRA") to aid in interpretation of language in the Employee Retirement Income Security Act of 1974 ("ERISA") but drawing interpretive inferences in part due to legislative history suggesting that ERISA be construed like LMRA); Pilot Life Ins. Co. v. Dedeaux, 481 U.S. 41, 47-51 (1987) (O'Connor, J.) (using case law concerning the McCarran-Ferguson Act to interpret ERISA); W. Air Lines, Inc. v. Bd. of Equalization, 480 U.S. 123, 130-31 \& n.* (1987) (O'Connor, J.) (using the Railroad Revitalization and Regulatory Reform Act of 1976 and Motor Carrier Act of 1980 to shed light on the language of the Airport and Airway Improvement Act); Trans World Airlines, Inc. v. Thurston, 469 U.S. 111, 121 \& n.16 (1985) (Powell, J.) (interpreting the Age Discrimination in Employment Act by turning to Title VII due to "similarity between the two statutes"). But see Nat'l Fed'n of Fed. Employees v. Dep't of the Interior, 526 U.S. 86, 93 (1999) (Breyer, J.) (stating that "linguistic differences" in two labor laws "tell us little" and declining to find interpretive significance in such differences); Russello v. United States, 464 U.S. 16, 25 (1983) (Blackmun, J.) (refusing to assess language in the Racketeer Influenced and Corrupt Organizations Act based on language in the Controlled Substances Act because "[1]anguage in one statute usually sheds little light upon the meaning of different language in another statute, even when the two are enacted at or about the same time"). For a few examples of interstatutory cross-referencing that show greater attention to historical context and the Court's own handiwork, see infra notes 268-69 and accompanying text. 


\section{A Single CongResS AND MULTIPLE STATUtory MEANINGS}

The provisions of Article I ensure that all legislation, prior to enactment, will go before and be voted on by legislators in the House of Representatives and in the Senate, and then be presented to the President. Despite this continuity in legislative process, the regular congressional and presidential elections and changing committee membership ensure ever-changing political dynamics. ${ }^{120}$ Furthermore, administrative agencies' changing personnel and leadership, and ever-evolving bodies of regulation, frequently modify the legal terrain and incentives for legislators to legislate on particular issues. As a matter of empirical fact, different individuals make up the Congress and the executive branch at different times, and no legislation is produced with identical supporting voters. Even without embracing public choice arguments about legislative incoherence in the context of group voting, one can comfortably state that no theory of statutory interpretation can sensibly be based on the claim of an identical congressional drafter and coalition behind two different statutes.

Nevertheless, opinions utilizing the one-Congress fiction interpretive technique frequently make primary-referent statutory comparisons using language that assumes some ideal unity of understanding, usage, and meaning about past laws, law in the legislative process when the primary statute was enacted, and sometimes even laws enacted after the primary statute. ${ }^{121}$ In opinions employing the one-

${ }^{120}$ See Shepsle, supra note 62, at 241, 244 (observing that even if legislative majorities and the President did not change, changing committee chair identities would change likely outcomes, and that legislative intent is impossible to locate because of similar "idiosyncratic, structural, procedural, and strategic factors"); see also Jerry L. Mashaw, The Economics of Politics and the Understanding of Public Law, 65 CHI.-KENT L. REV. 123, 134 (1989) ("Statutes are ... the vector sum of political forces expressed through some institutional matrix which has had profound, but probably unpredictable and untraceable, effects on the policies actually expressed." (emphasis omitted)), quoted in Shepsle, supra note 62, at 242.

${ }^{121}$ Professor Popkin has noted that an assumption of an ideal, unitary drafter is often evident in the jurisprudence of Justice Scalia. See Popkin, supra note 6, at 114345, 1148-52 (making this point through a discussion of the standards of writing style and grammar to which Justice Scalia holds Congress, and his general assumptions about the coherence of the body of federal statutes); see also WILLIAM D. POPKIN, STATUTES IN COURT: THE HISTORY AND THEORY OF STATUTORY INTERPRETATION 23946 (1999) (exploring judicial approaches to arguments grounded in comparisons of multiple statutes). As shown in this Article, Justice Scalia is far from alone in his embrace of the one-Congress fiction. See generally supra Part I (discussing the use of the fiction by other judges and academics). While other legal systems, such as that of Great Britain, strive for unity of drafting strategies and interpretive conventions, see P.S. ATIYAH \& ROBERT S. SUMmers, FORM AND SUBSTANCE IN ANGLO-AMERICAN LAW 
Congress fiction, the legislature is often anthropomorphized, in the sense that it is treated as if it were a single natural person, albeit a person of superhuman omniscience and consistency of style. Such an approach cannot and does not appear to rest on some unsupportable assertion about a static collection of political actors.

Nevertheless, the following sections assume a highly unrealistic static political environment. As shown below, even with such a static set of political actors, it remains difficult to justify the one-Congress fiction technique based on some other explanation or theory of politics and law. Building primarily off of theories of politics and legislation rooted in Positive Political Theory ("PPT"), ${ }^{122}$ this Part discusses a few common situations in which the language of statutes is likely to change without necessarily reflecting an intent to change statutory meaning. $^{123}$

96-114, 298-335 (1987), the one-Congress fiction interpretive ploy does not seem to be rooted in any actual uniform shared drafting or interpretive conventions. None of the examples discussed in Part I devote attention to drafting and interpretive conventions prevalent at the time of the primary statute's drafting. Instead, referent laws regularly are separated by many years from the primary statute's enactment date, and are therefore drafted against a different set of political assumptions, drafting practices, and even different judicial precedents that shed light on interpretive practices.

${ }^{122}$ For an in depth discussion of the implications and attributes of Positive Political Theory, see Symposium, Positive Political Theory and Public Law, 80 GEO. L.J. 457 (1992). Professors Farber and Frickey define PPT as "non-normative, rational-choice theories of political institutions." Daniel A. Farber \& Philip P. Frickey, Foreword: Positive Political Theory in the Nineties, 80 GEO. L.J. 457, 462 (1992). PPT scholarship and theories focus upon how institutional settings influence political processes and outcomes. See $i d$. at 460-63 (describing PPT in broad terms). For additional characterization of PPT, see ESKRIDGE \& FRICKEY, supra note 9, at 61-66. PPT theories assume that political actors are aware of each other, that they anticipate each others' actions and adjust to accomplish their own goals, that goals range from the self-interested to the ideological, and that institutional arrangements will influence how political actors interact. See Farber \& Frickey, supra at 462 (using the term PPT as a non-normative framework that examines the goals and motivations of political actors). PPT shares many of its basic assumptions with public choice theory, but public choice theory focuses more on general political propensities such as rent seeking and vote cycling (as suggested by Kenneth Arrow), while PPT focuses more on how political processes and institutions influence ultimate political outcomes. See id. at 460-62 (exploring the theoretical and practical differences between PPT and public choice theory). Public choice theorists also tend to assume a simpler set of rational impulses of political actors, particularly, but not exclusively, actors' desire for wealth or politicians' desire for re-election. See William N. Eskridge, Jr., Politics Without Romance: Implications of Public Choice Theory for Statutory Interpretation, 74 VA. L. REV. 275, 320 (1988) ("Though legislators do have strong incentives to be reelected, institutional process scholars argue that legislators' behavior is also influenced by a rich array of other factors, including their desire to contribute to sound policy and to gain respect within the legislature.").

${ }^{123}$ For a discussion of the changing nature of legislation due to the growth of the administrative state and for a discussion of a "preliminary theory of modern legislation," see Edward L. Rubin, Law and Legislation in the Administrative State, 89 ColuM. L. 


\section{A. A Fictional Two-Statute, Permanent Political Personnel World}

This section assumes the following simplified political context. This hypothetical world draws in its basic conception on earlier works on statutory interpretation and the legislative process, especially those of Professors Eskridge, Ferejohn, McCubbins, and the three-professor entity referring to itself as "McNollgast." mary statute (S1) is before the courts. S1 and an earlier-enacted referent statute, S2, both were enacted during a time when the same exact personnel held office in the House of Representatives, the Senate, and the White House. This discussion also assumes that, as in the cases discussed above in Part I, S1 and S2 have provisions addressing an issue of sufficient similarity in language and subject that litigants and courts would at least be tempted to engage in the one-Congress fiction interpretation methodology and draw inferences from crossreferencing these provisions in S1 and S2.

Both S1 and S2 are statutes that empower administrative agencies to implement their respective enabling acts. ${ }^{125}$ For purposes of this

REV. 369, 371 (1989).

${ }^{124}$ See, e.g., William N. Eskridge, Jr., Overriding Supreme Court Statutory Interpretation Decisions, 101 YALE L.J. 331, 334 (1991) [hereinafter Eskridge, Overriding Supreme Court Statutory Interpretation Decisions] ("[P]osit[ing] that a dynamic game exists between the Court, the relevant congressional committees, Congress, and the President... [in which] ultimate statutory policy is set through a sequential process by which each player-including the Court-tries to impose its policy preferences."); William N. Eskridge, Jr., Overmuling Statutory Precedents, 76 GEO. L.J. 1361, 1362 (1988) (examining critically and historically the "super-strong presumption" against overruling statutory" precedents); William N. Eskridge, Jr. \& John Ferejohn, The Article I, Section 7 Game, 80 GEO. L.J. 523, 529 (1992) ("drawing upon formal models developed by positive political theory" to analyze Article $1, \S 7$ of the U.S. Constitution "as a sequential game"); John Ferejohn \& Charles Shipan, Congressional Influence on Bureaucracy, 6 J.L. ECON. \& ORG. 1 (1990) (arguing that sequence is highly important in the context of a separation-of-powers regime); Matthew D. McCubbins et al., Structure and Process, Politics and Policy: Administrative Arrangements and the Political Control of Agencies, 75 VA. L. REV. 431, 432 (1989) (advancing the proposition that administrative procedures are "one means of guiding agencies to make decisions that are consistent with the preferences of the legislative coalition (including the President) that succeeded in passing the agency's enabling legislation, but without requiring the members of that coalition to monitor, or ... be aware of, the nature of the agency's actions."); McNollgast, Positive Canons: The Role of Legislative Bargains in Statutory Interpretation, 80 GEO. L.J. 705, 706 (1992) (setting forth a "positive theory of the legislative process").

${ }^{125}$ The one-Congress fiction is similarly used in construing criminal law statutes, but due to significant differences in how criminal laws empower a similar agent-a prosecutor-and how disparate criminal law provisions must be considered in connection with similar acts, such as using a gun during a crime, the use of the one-Congress fiction in the context of criminal law is arguably less problematic. In any event, this Article and this Part's hypothetical setting focus on interpretation cases and legislative 
discussion, the exact content of the primary-referent provisions is unimportant, but such provisions in Supreme Court opinions tend to regard subjects that are found in numerous bodies of law, such as fee- or cost-shifting provisions, citizen suit provisions, remedies, key definitions of persons covered by a law, or sometimes laws addressing a similar social or market issue such as natural resource extraction rights or environmental pollution where administrators are instructed to consider particular factors. While S1 and S2 were enacted during a period when the same politicians held office in all three branches, I will assume that the two laws were enacted a few years apart.

Like all laws, the earlier S2 was enacted after consideration and debate by legislative committees and then on the floor of the legislature. Coalitions supporting and opposing S2 sought to convince politicians in the legislature and the White House through words, possible campaign contributions, and electoral promises to support their side in the legislative drafting process. Among the actors in this legislative process are agency officials familiar with similar laws or perhaps earlier versions of a similarly titled law. Politicians in the legislative and executive branch also have past experience with such laws and, depending on the exact statutory area of coverage, may seek either to take an active political role to claim credit, or instead to engage in risk avoidance and allow others to lead in the legislative process. ${ }^{126}$ Among the information all such actors are likely to consider in the drafting process, at least in their institutional capacities and when assisted by experienced counsel and lobbyists, is the track record of similar laws in achieving their purposes, in their treatment and implementation before agencies, and in disputes before the courts. I will assume that such information goes into the legislative mix, although surely not all legislators or executive branch officials will have actual awareness of all such information. ${ }^{127}$ As positive political theorists have concluded

process in the context of enabling acts linked to the administrative state.

${ }^{12 '}$ See JOHN HART ELY, DEMOCRACY AND DISTRUST 131-33 (1980) (discussing reasons legislators will avoid tough issues and delegate such decision making to administrative agencies); DAVI R. MAYHEW, CONGRESS: THE ELECTORAL CONNECTION 13-77 (1974) (developing the theory that politicians act as re-election-seeking machines); Eskridge \& Ferejohn, supra note 124, at 534 ("There are numerous reasons for Congress's willingness to delegate significant lawmaking power to agencies, including ... the congressional inclination to avoid or defer controversial policy decisions.").

1.27 As Professors Mashaw and Shepsle have noted, the ways in which these many political variables will influence resulting language is difficult to predict. See Mashaw, supra note 120 , at 134 (discussing statutes as "the vector sum of political forces expressed through some institutional matrix which has profound, but probably unpredictable and untraceable, effects on the policies actually expressed"); Shepsle, supra note 62 , at 244 (arguing that legislative outcomes are often dependent upon "idiosyn- 
in past examinations of political processes, it is fair to assume that either personally or through proxies such as political parties, counsel, legislative allies, knowledgeable committee members, and affected citizens and interest groups, legislators and the President will, at a minimum, have available for their consideration information about the significant implications of most bills and their language choices. ${ }^{128}$

Once S2 is enacted, it does not end its legislative voyage. To borrow and modify slightly a nautical metaphor used by Professor Aleinikoff, S2, like any law, will progress in its implementation much as would a ship after its launching. ${ }^{129}$ Each actor and institution involved in S2's enactment and implementation will reveal and flesh out the implications of S2's language choices, and by these implementation decisions and challenges surely stretch, shrink, and modify S2's reach and import from what supporting coalitions hoped for in S2's enactment battle. ${ }^{\mathrm{d} 0}$ Many such implementation decisions will be

cratic, structural, procedural, and strategic factors").

${ }^{128}$ See McNollgast, supra note 124, at 711-12, 716-18 (arguing that the "pragmatic view" of legislative battles assumes that legislative partisans will seek to further their preferences opportunistically but ultimately reach a statutory compromise); $c f$. Eskridge \& Ferejohn, supra note 124, at 553-54 (noting countervailing forces restraining efforts to subvert congressional preferences through the manipulation of legislative history). Positive political theorists' scholarship and theories focus upon how institutional settings influence political process and outcomes, emphasizing how partisans will seek to further their interests in ways influenced by their institutional setting. See ESKRIDGE \& FRICKEY, supra note 9, at 61-66; Farber \& Frickey, supra note 122, at 460-62.

${ }^{129}$ See T. Alexander Aleinikoff, Updating Statutory Interpretation, 87 MICH. L. REv. 20, 21 (1988) (employing this metaphor to illustrate his contentions concerning statutory interpretation). Professor Aleinikoff uses his metaphor to conclude with the argument that courts can and should interpret laws to ensure their "current coherence in the law." Id. at 52. This Article agrees with Aleinikoff's idea that a statute's voyage fleshes out a law's implications, see $i d$. at 57 , but questions the proposition that courts and litigants should be encouraged case by case to make all of the law coherent at any one time. See infra Part IV.

${ }^{130}$ See Aleinikoff, supra note 129, at 57 ("Each of these interactions changes, or fills out, the meaning of the statute."); see also Eskridge \& Ferejohn, supra note 124, at 527 (discussing how the involvement of the administrative state in the "sequential game" making up the legislative process renders the process more dynamic and justifies a modification of modes of interpretation to preserve the Constitution's "original value"); McCubbins et al., supra note 124, at 435-40 (exploring how new legislation often is not a viable response to a disliked agency interpretation due to the way different "status quo policies" change coalitional politics and resulting legislative outcomes). See generally William N. Eskridge, Jr., Interpreting Legislative Inaction, 87 MICH. L. REv. 67 (1988) (discussing the implications of legislative inaction following the Supreme Court's interpretations and many potential meanings of such inaction). The Court in Brown $\mathcal{E}^{2}$ Williamson assumed such a post-enactment elucidation of statutory meaning, but focused on post-enactment legislative activity and its implications for the primary statute's meaning: "At the time a statute is enacted, it may have a range of plausible meanings. Over time, however, subsequent acts can shape or focus those meanings." 
purely political and discretionary, but others, particularly regulatory choices made by agencies and judicial statutory constructions of S2, will begin to lock S2 into a more fixed form. These last two implementation steps-regulation promulgation and judicial statutory construction-not only create a more durable form of S2, but are also likely to be highly visible and known to affected constituencies, including supporting coalitions, agencies, opponents, and elected politicians themselves. Even without actual regulation promulgation pursuant to a particular $\mathrm{S} 2$ provision, adjudicatory actions by an agency or citizen litigation under S2 or the APA will further reveal the import and meaning of S2's language and structure. ${ }^{131}$ In the forthcoming discussion of the later enactment, SI (the primary statute), I assume that the implementation and interpretation of S2 have provided at least a track record regarding S2's referent language choice.

A few years after S2's enactment, $\mathrm{S} 1$ is proposed. Once again, as occurred with S2, S1 goes through a process of political debate and scrutiny. The historical context of $\mathrm{S} 1$, however, is, at a minimum, different from S2's enactment due to the presence of S2 as well as to the history of S2's implementation. Whether one assumes what Professor Popkin refers to as an ideal unitary drafter, ${ }^{132}$ or just some objective version of a legislator who either on her own or through proxies and agents has information before her regarding S2's history, S1's enactment politics will adjust in light of the track record of S2. Much as Professor McCubbins and his co-authors, and Professors Eskridge and Ferejohn, show how a single statute's politics and coalitional dynamics unavoidably change once an unexpected and authoritative statutory interpretation takes place, so too players in the S1 legislative process will adjust their strategies in light of the $S 2$ experience. ${ }^{133}$ To the extent that other potential referents (S3, $\mathrm{S} 4$ and so on) exist, informa-

120 S. Ct. 1291, 1306 (2000).

${ }^{131}$ Many such interpretive steps will not preclude the interpreting agency from later changing statutory interpretations or approaches, see Chevron U.S.A., Inc. v. Natural Res. Def. Council, Inc., 467 U.S. 837, 842-43 (1984) (stating that where Congress has not "directly addressed" the particular issue at hand, an agency's interpretation of "the statute which it administers" is entitled to judicial deference), but due to the delays, burdens, and frequent litigation faced by an agency that changes regulatory policy, administrative agencies do not lightly deviate from a policy or a statutory interpretation once it has been officially stated, see Thomas O. McGarity, Some Thoughts on "Deossiffing" the Rulemaking Process, 41 DUKE L.J. 1385, 1396-1436 (1992) (exploring reasons why agency policies often ossify).

${ }^{1 S z}$ See Popkin, supra note 6, at 1148-52 (analyzing Justice Scalia's interpretation of multiple statutes as sharing common meaning because of similar language and structure).

See supra text accompanying notes $122-24$. 
tion about those statutes' successes, failures, and interpretations may be added to the legislative mix.

Can linguistic comparisons about language differences justify an inference that these laws have a different meaning or reflect a different legislative intent? The basic hypothesis developed in the succeeding paragraphs is that S1's language choices, particularly language changes from the referent $S 2$ language, can result from numerous potential types of legislative activity, goals, and coalition politics, as well as from drafter ignorance, and therefore linguistic differences should not necessarily be interpreted to require a different interpretation of statutory meaning. Judge Easterbrook asserts that it is "impossible to reason from one statute to another" due to the complicated institutional setting and collective nature of the legislature. ${ }^{134}$ Judge Easterbrook may have overstated the possibility that legislative actors will act with knowledge of a larger statutory context, but as shown below, his skepticism is well founded.

\section{B. Committee Turfs, Expertise, and Language Choice}

Bills emerge from the legislative work of committees and subcommittees, each of which deals with a different substantive area of the law. Moreover, different committees drafting new legislative proposals do so against a different baseline of existing law. ${ }^{135}$ The current state of workplace safety and health law differs from that of environmental law, which in turn differs substantially from that of agricultural law. The United States Code is not a complete, closed system of rules. Instead, each statute in its voyage has its implications revealed and its bounds stretched or shrunk by agency and court interpretations, as well as by political and societal developments. ${ }^{136}$ Political activity regarding S1 may be linked to S2, but it is more likely that S2's particular implications and baseline environment will differ from those facing S1 coalitions due to S1's own distinct implementation history. If one assumes that all legislative proposals reflect numerous legislative

${ }^{134}$ Easterbrook, supra note 72, at 547.

${ }^{135}$ See CHRISTOPHER J. DEERING \& STEVEN S. SMITH, COMMITTEES IN CONGRESS (3d ed. 1997) (exploring the role of committee political power); Kenneth A. Shepsle \& Barry R. Weingast, The Institutional Foundations of Committee Power, 81 AM. POL. SCI. REV. 85 (1987) (seeking to explain why committees are such powerful institutions in the U.S. Congress).

${ }^{136}$ See Edwards v. United States, 814 F.2d 486, 488 (7th Cir. 1987) (rejecting the notion that legislators examine the whole body of existing law before enacting a new statute); see also supra note 55 and accompanying text. 
players' purposive acts designed either to achieve a policy goal or, at least, to please each actor's constituencies, then language choices will vary depending on the larger context of relevant law. ${ }^{137}$ The legal context for each subject area will vary depending on the baseline of other laws, regulations, court decisions, and political perceptions about preexisting laws' merits. Each committee involved in the drafting process, as well as each administrative agency and each affected constituency, is likely to be focused upon interrelated laws regarding overlapping subject matter.

The central role of legislative staff and counsel offers one of the few reasons to believe that disparate laws may use language in consistent ways. ${ }^{138}$ Such staff surely are one of the main reasons that, despite public choice theory predictions of legislative incoherence, laws actually often make a good deal of sense. ${ }^{139}$ The President's final signature

${ }^{137}$ The concept is that legislators are seeking to achieve a goal and do so in a purposeful manner. The assumption of "purposive activity" is not coterminous with advocacy of expanding statutes to achieve their primary purpose, nor is it the same as assuming that the end result of the legislative process will necessarily be coherent or public-regarding. See Karkkainen, supra note 9, at 412-13 (contrasting Justice Scalia's limited attention to statutory purpose while noting Scalia's rejection of use of purpose to expand a statute's reach). An assumption of purposive legislative activity can be embraced by advocates of enforcement of the particular "legislative bargain" (such as Judge Easterbrook), by advocates who construe statutes to further their "public regarding" ends (such as Professor Macey), or by advocates of expansive readings of statutes to further their main purpose or perhaps several purposes. See, e.g., Easterbrook, supra note 72 , at 533-34, 543 (stating that judges "try to determine how the Congress that enacted the statute actually resolved or would have resolved" the statutory ambiguity, but arguing courts should refrain from modifying the reach or "domain" of a statute); Jonathan R. Macey, Promoting Public-Regarding Legislation Through Statutory Interpretation: An Interest Group Model, 86 CoLUM. L. REv. 223, 223-25 (1986) (arguing that to deter special interest legislative rent-seeking, courts should construe laws not to implement the legislative bargain, but to further public-regarding ends). Even Kenneth Shepsle, who posits that the legislative processes' many steps and actors result in unpredictable legislation that is likely to be incoherent and "morally indefensible," starts with the assumption that the various legislative actors will strive in a purposive manner to further their goals. Shepsle, supra note 62 , at $241-45$ (developing a model assuming individual legislators have policy preferences and seek their enactment).

${ }_{1 \times x}$ See Eskridge, Overriding Supreme Court Statutory Interpretation Decisions, supra note 124 , at 339 (stating that "staffs are essential to monitoring judicial decisions[,] ... organizing congressional hearings[,] ... and drafting committee reports and statutes").

${ }^{134}$ See id. at 343 (arguing that legislators and committee staff are aware of Supreme Court statutory decisions). But see Robert A. Katzmann, Bridging the Statutory Gulf Between Courts and Congress: A Challenge for Positive Political Theory, 80 GEO. L.J. 653, 662 (1992) (reporting the results of a project on statutory revision finding that, in most instances, committee staff were not aware of relevant court decisions unless they were "major" in some way). Furthermore, as a few readers of drafts of this Article suggested, the current ready availability of computer-assisted research in legal databases makes 
or veto also will reduce the incoherence predicted by vote cycling theory. ${ }^{140}$ A theory of statutory interpretation that relies on the existence of diligent legislative counsel and staff, however, is highly unlikely to be an implicit basis for the Court's main advocates of the oneCongress fiction. For textualists like Justice Scalia, the views of legislative counsel and staff are seen as unworthy of interpretive weight due to the unelected status of such counsel and staff, their own political agendas, and their alleged manipulation of legislative history to further ends unable to be achieved in actual legislation. ${ }^{141}$

Legislative drafters and their staff may look further afield to subject areas under other committees' jurisdiction, but such analysis would surely be given less weight than attention to what may become a modified body of law covering related subjects. ${ }^{142}$ Committee expertise and research are unlikely to reach far beyond a committee's subject coverage. Drafters' efforts to harmonize new bills with preexisting law are much more likely to focus on laws attacking a similar problem or regulating the same industries than they are to focus on unrelated bodies of law that may share legal structures. Given a choice of either using similar language in two statutes that regulate unrelated fields or choosing particular SI language that will address a substantive problem, a rational drafter will surely choose to use lan-

research into statutory language an easy option for legislative partisans and staff.

${ }^{140}$ See William T. Mayton, The Possibilities of Collective Choice: Arrow's Theorem, Article I, and the Delegation of Legislative Power to Administrative Agencies, 1986 DUkE L.J. 948 (exploring reasons Article I's process creates the possibility of rational outcomes despite frequent contrary interpretations of Kenneth Arrow's theorem).

${ }^{141}$ In the words of Justice Scalia, "anyone familiar" with the legislative process "is well aware" that staff insert legislative history materials "to influence judicial construction.” Blanchard v. Bergeron, 489 U.S. 87, $98-99$ (1989) (Scalia, J., concurring), quoted and discussed in William T. Mayton, Law Among the Pleonasms: The Futility and Aconstitutionality of Legislative History in Statutory Interpretation, 41 EMORY L.J. 113, 151 (1992). Scalia continues, "What a heady feeling it must be for a young staffer, to know that his or her citation of obscure district court cases can transform them into the law of the land, thereafter dutifully to be observed by the Supreme Court itself." 489 U.S. at 99 . Farber and Frickey characterize Justice Scalia as believing that legislative staff "connive to subvert the judicial function by planting their ... subjective desires about statutory meaning into committee reports ...." Daniel A. Farber \& Philip P. Frickey, Legislative Intent and Public Choice, 74 VA. L. REv. 423, 439 (1988).

142 For example, in 1996, the hotly debated issue of lender liability under CERCLA was addressed through a statutory amendment coming out of banking committees rather than the more typical environmental committees. As perhaps should have been anticipated, the language and structure ultimately used in the 1996 amendments was flawed and only partially dovetailed with preexisting law. See William W. Buzbee, CERCLA's New Safe Harbors for Banks, Lenders and Fiduciaries, 26 ENVTL. L. REP. 10656, 10662 (1996) (discussing language imperfections that are likely to result when amendments are passed as part of appropriation bills). 
guage that addresses the substantive problem.

To make the same point from another perspective, only an irrational drafter would worry about linguistic consistency with unrelated bodies of law and give lesser attention to linked bodies of law. Similarly, and perhaps more importantly, no drafter could predict to which unrelated bodies of law reviewing courts engaging in the oneCongress fiction in statutory interpretation might look. Purposive drafters would look primarily to linked bodies of law. ${ }^{143}$

\section{The Better Statutory Mousetrap}

Even where S1's enacting coalitions actually draft S1 with S2 in mind, different statutory language may be embraced to achieve the same result achieved under S2. Once S2's implications have been fleshed out through litigation and agency implementation activities, S1 legislative actors may be pleased with $\mathrm{S} 2$ and consider S2 in its implemented state an appropriate template for S1. This political embrace of S2's meaning or results as revealed through litigation and implementation decisions does not, however, mean that S2's actual language choices will be repeated in S1. The S1 legislative actors may seek to embrace the implemented S2 by putting in more explicit language or provisions intended to ensure that S1 will share the perceived successes of $\mathrm{S} 2$.

A good example of such language modifications in the search for a better statutory mousetrap is the history of citizen suit provisions added to many environmental laws since 1970. The National Environmental Policy Act ("NEPA") did not include citizen suit provisions, but courts construing NEPA combined it with the Administrative Procedure Act to allow citizen litigation challenging illegal government actions under NEPA. ${ }^{144}$ Advocates of environmental protection and executive action in compliance with environmental laws saw in NEPA, as interpreted by the courts confronted with creative litigation as well as in other early environmental laws engendering citizen litigation in

${ }^{145}$ Even with a superhuman legislative drafter, the complex legislative terrain and many legislative actors are likely to wrest linguistic control from that drafter for a wide variety of reasons. See Mashaw, supra note 120, at 146 (observing that little can be said with certainty about the "mix" of legislator motivations); Shepsle, supra note 62, at 24546 (explaining how the committee process, legislator deliberation, procedures for amendment, and deference to the rule of seniority affect the bills ultimately enacted into law).

${ }^{144}$ See Public Citizen v. Kantor, 864 F. Supp. 208, 211 (D.D.C. 1994) (exploring the NEPA and APA cause of action link). 
the 1960s and early 1970s, sound models for explicit legislative grants of citizen suit causes of action. ${ }^{145}$ Were one merely to compare NEPA with later laws in a vacuum, without consideration of NEPA's voyage once launched, one might conclude either that early environmental laws such as NEPA (S2 in this discussion) were not meant to authorize citizen litigation, or that $\mathrm{S} 1$ in its inclusion of a citizen suit provision was meant to be different from NEPA. While S1 provisions, such as citizen suit provisions, have tended to include additional requirements and to authorize additional forms of litigation generally not part of litigation under NEPA and other early environmental laws, S1's meaning is not further illuminated by assuming that the inclusion of explicit language indicates an intent to vary statutory content, meaning, or results. Legislators and all actors in the legislative process should be presumed to be rational purposive beings, even if their complex interactions and the political process render political outcomes difficult to predict. ${ }^{146}$ Locking in successes evident under an earlier statute does not necessarily mean identical language will be embraced. ${ }^{147}$

The likelihood that $\mathrm{S} 1$ coalitions may perceive a need to add specific language is particularly high when an agency interpretation of a statutory provision in S2 is viewed as desirable. In enacting S1, rational actors will take cognizance of the implications of the Chevron case. ${ }^{148}$ In Cheoron, the Supreme Court articulated a two-step framework for judicial review of agency interpretations of law. As many others have explored in voluminous scholarship on Cheoron, an agency interpretation of law in the context of a statutory gap or ambiguity should stand if it is a reasonable construction of law, especially in cases in which the implementing agency reconciles conflicting policies

${ }^{145}$ See Barton $\mathrm{H}$. Thompson, Jr., The Continuing Innovation of Citizen Enforcement 2000 U. ILL. L. REV. 185, 196-97 (noting that first explicit citizen suit provisions were viewed as building on the "trend of existing law" (quoting 1 ENVIRONMENTAL POLICY DIV., LibraRY OF CONGRess, 93D CoNG., A Legislative History OF THE CLEAN AIR AMENDMENTS OF 1970, at 214 (Comm. Print 1974)).

${ }^{146}$ See supra note 137 and accompanying text for a discussion of how an assumption of "purposive" activity is distinct from an interpretive method that seeks to expand upon discerned statutory purposes.

${ }_{147}$ See, e.g., United States v. Monia, 317 U.S. 424, 431-47 (1943) (Frankfurter, J., dissenting) (explaining why all of the surrounding historical circumstances of a statute's enactment, and not merely the "naked words" of its text, need to be consulted to ascertain statutory meaning). For further discussion of Justice Frankfurter's argument that two statutes with different language nevertheless were easily construed to have the same purpose, see infra text accompanying notes 182-84.

${ }^{148}$ Chevron U.S.A., Inc. v. Natural Res. Def. Council, Inc., 467 U.S. 837 (1984). 
or acts in a complex technical context. ${ }^{149}$ Only if a disputed provision answers the "precise question at issue" ${ }^{\text {"150 }}$ does the agency's construction have to be consistent with the Court's preferred interpretation. S1 coalitions may modify S1's language to seek to prompt future agency interpretations of $\mathrm{S} 1$ that will resemble already existing interpretations of S2. Here, too, different language choices in S1 and S2 would not reveal rejection of S2 and its agency interpretation, but constitute an embrace of S2 and its particular implementation. ${ }^{151}$

The opposite situation is also likely. S2 may be interpreted by an agency or court in an unexpected manner that unsettles the expectations of the coalitions that succeeded in enacting S2. S1 drafters may share the same goals as drafters and supporters of S2, but S1 drafters, aware of S2's uneasy statutory voyage, will choose different language to address the problems revealed by the unexpected interpretation. Much as coalitions battling to return S2 to its anticipated status quo will have to overcome a new status quo created by the unexpected interpretation, S1 drafters may encounter many political hurdles in seeking to address even a known linguistic risk. ${ }^{152}$ Furthermore, given the willingness of judges engaged in the one-Congress fiction to construe earlier laws in light of later laws' linguistic choices, the later coalitions drafting S1 face the potential conundrum of unsettling S2 meaning by using more particular language in S1. Justice O'Connor created just such a conundrum in Gebser ${ }^{153}$ when she and a majority of the Court construed Title IX, a 1972 civil rights law, only to grant a circumscribed cause of action for damages because Congress had more explicitly addressed the issue twelve years later in a differently

14" For a discussion of Cheoron and citations to the vast literature analyzing the case, see ESKRIDGE \& FRICKEY, supra note 9, at 860-63.

${ }^{15 n}$ Cheoron, 467 U.S. at 842.

${ }^{151}$ Such a locking-in of a particular statutory interpretation of S2 would in one sense constitute a rejection of S2. S1 coalitions would be narrowing the range of statutory indeterminacy allowed under S2 with the goal of embracing a particular read of S2's language. See Henry P. Monaghan, Marbury and the Administrative State, 83 COLUM. L. REv. 1, 6 (1983) (pointing out in an article published shortly before Cheo ron that, in any judicial review of agency action, courts must reach a conclusion about "the boundaries of delegated authority").

${ }^{152}$ The dynamic political "game" that will follow an unexpected law interpretation has been explored in depth by Professors Eskridge, McCubbins, and McNollgast. For citations to their several works exploring this complex game, see supra notes 122-24. For a concise summary of theories of politics and legislative process addressing political dynamics following such a law interpretation, see ESKRIDGE \& FRICKEY, supra note 9, at $61-66$

15: See supra notes 101-14 and accompanying text (discussing the Gebser decision in detail). 
worded civil rights law. ${ }^{154}$ When used to construe earlier laws in light of the linguistic choices made in later laws, the one-Congress fiction creates odd incentives for legislators to avoid more precisely worded provisions. $^{155}$

Legislative actors will also take into account Supreme Court interpretations of earlier laws and use, where necessary, different language to ensure that the new law (S1) will pass muster in the courts. For example, several of the citizen suit provisions cross-referenced by the Court in Bennett contained language closely parroting the Court's language in Sierra Club v. Morton. ${ }^{156}$ The ESA's language did not contain the same language, but a future legislature's insertion of language into a statute to conform to a Court-articulated standing requirement does not mean that earlier or later statutes lacking similar language should be construed to reveal a different legislative meaning. The Supreme Court's own standing criteria have varied over recent decades, with prudential and APA-based requirements becoming constitutional. ${ }^{157}$ In the context of the Bennett use of the one-Congress fiction, nothing in the history of the ESA or most of the cross-referenced statutory provisions indicates an intent to modify the contours of prudential standing hurdles under the "zone of interest" test.

Finally, in the search for "a better statutory mousetrap," legislators may pick out portions of past laws as a template for a later law but vary the primary statute's language or coverage in other critical respects due to different statutory structures, enforcement provisions, and remedies. For example, in Lorillard v. Pons, the Court found interstatutory comparison informative, especially when combined with an examination of case exegesis of the referent provision and legislative history explicitly linking the two laws. ${ }^{158}$ The Court declined, however, to draw interpretive inferences from a different proposed statutory comparison despite the two laws' "important similarities" and prohibitions "derived in haec verba" from the suggested referent. The Court explained, "it is the remedial and procedural provisions of the two

${ }^{154}$ See id. (discussing Gebser).

155 In this respect, the one-Congress fiction undercuts the "legislative excellence" argument for textualism. For a fuller discussion of theories of legislative excellence, see infra notes 228-34 and accompanying text. sion).

See supra notes $41-48$ and accompanying text (discussing the Sierra Club deci-

${ }^{157}$ See Sunstein, supra note 43 , at 181-82 (reviewing the impact of the APA on the Supreme Court's standing requirements).

${ }^{158} 434$ U.S. 575, 581-84 (1978). 
laws that are crucial and there we find significant differences."159

\section{Electoral Politics and Language Choice}

Modified language can also be added to S1 to embrace S2's implementation, but for reasons that may be electoral. Citizens and interest groups involved in S1 enactment battles may favor portions of S2 as a template for $\mathrm{S} 1$ and pressure legislators and the President to go further with more specific language. To show sensitivity to constituency pressures, legislators and the President may go along with such desires without any intent to achieve different results in S1. Not all politicians are the pure re-election machines posited by David Mayhew, but all politicians must be sensitive to constituency desires. ${ }^{160}$

Examples of such statutory language changes attributable to constituency pressure for more detailed language to achieve the same ends obtained with less specific S2 language are difficult to identify with certainty. ${ }^{161}$ No participant in the legislative process would generally benefit from identifying such motivations for particular statutory language. Environmental laws' ever-increasing specificity and length, however, are consistent with such a hypothesis. ${ }^{162}$ Especially in an era of divided government, where the executive branch and the legislature are controlled by different parties, coalitions will seek greater statutory detail. In such a context, later S1 statutes will often contain additional layers of statutory language. These linguistic accretions reveal the ability of drafters to achieve statutory ends with greater specificity, but they do not necessarily reveal a different statutory meaning from laws enacted earlier. Once again, even with an identical set of elected politicians participating in the legislative process, different language does not necessarily signify different statutory

${ }^{154}$ Id. at 584.

Iix) See MAYHEw, supra note 126.

"For a discussion of reasons for "congressional micromanagement" through statutory detail and the implications of such detail in the context of textualist interpretive methods, see Michael Herz, Judicial Textualism Meets Congressional Micromanagement: A Potential Collision in Clean Air Act Interpretation, 16 HARV. ENVTL. L. REv. 175 (1992).

${ }^{102}$ For three works tracing the interaction of environmental law statutes and judicial review of such enactments, see Daniel A. Farber, Is the Supreme Court Irrelevant? Reflections on the Judicial Role in Environmental Law, 81 MINN. L. REV. 547 (1997); Robert Glicksman \& Christopher H. Schroeder, EPA and the Courts: Twenty Years of Law and Politics, LAW \& ConTEMP. ProbS., Autumn 1991, at 249; Richard E. Levy \& Robert L. Glicksman, Judicial Activism and Restraint in the Supreme Court's Environmental Law Decisions, 42 VAND. L. REv. 343 (1989). 
meaning or legislative intent. ${ }^{163}$

\section{E. Retain or Modify S2 Language?}

The last conundrum faced by a legislative drafter of S1 in a world where courts engage in the one-Congress fiction is the decision whether to retain or modify language used in a pre-existing potential S2 referent. This section's discussion assumes for the sake of argument, in an unrealistic leap, that a drafter might somehow be able to anticipate what $\mathrm{S} 2$ referents would be consulted to construe S1. Slight language modification could lead to a conclusion that such different language reflects a different statutory meaning, as concluded in the Bennett string citation, ${ }^{164}$ or it could be interpreted to support a similar legal conclusion, as Justice Scalia also concludes in his "zone of interest" discussion in Bennett, with reference to the Trafficante decision. ${ }^{165}$ In a world of courts engaging in the one-Congress fiction, and of litigators, in turn, seeking arguments based on cross-referencing of isolated statutory provisions, drafters adopting any varied language in S1 could not only lead a court to discern a significant legal difference from S2, but courts looking forward and backward in time might even change their construction of S2 in light of different language choices in S1. Even an all-seeing and omniscient drafter, with the ability to foretell which statutes would be cross-referenced, would not be able to predict how language changes in S1 might unsettle the law. As suggested above, the forward- and backward-looking aspects of the inter-

${ }^{163}$ Professor McChesney even posits, based on theoretical and anecdotal analysis, that politicians will embrace potential statutory changes that they actually do not support, all in an effort to attract attention and monetary support from affected constituencies. FRED S. MCCHESNEY, MONEY FOR NOTHING: POLITICS, RENT EXTRACTION, AND POLITICAL EXTORTION 56-58 (1997). While McChesney focuses on what are in essence illusory threats of legislative change, it is likely that some threatened bills would actually gain sufficient support to be enacted. Similarly, but perhaps in an opposite phenomenon, legislators will often propose legislation that has virtually no chance of passage, perhaps hoping to garner political and monetary support for a doomed effort. Some of the more extreme "regulatory reform" proposals of the 104th Congress were likely politically dead on arrival, but they may have made political sense for politicians engaged in the sort of rent seeking McChesney critiques. See William W. Buzbee, Regulatory Reform or Statutory Muddle: The "Legislative Mirage" of Single Statute Regulatory Reform, 5 N.Y.U. ENVTL. L.J. 298, 313-24 (1996) (discussing regulatory reform legislative proposals and their reception).

${ }^{164}$ See supra note 20 and accompanying text.

${ }^{165}$ Bennett v. Spear, 520 U.S. 154, 165-66 (1997). The statutory language construed in Trafficante, however, is actually much like that just construed in Bennett to be legally distinguishable from the ESA's citizen suit language. See supra Part I.B.1 (detailing the use of multiple statute cross-referencing in the Bennett decision). 
pretive move of the one-Congress fiction make risky any attempts in later legislation to achieve with greater particularity what is already provided for in earlier laws, albeit in different language. ${ }^{160}$

While Brown $\mathcal{E}^{\circ}$ Williamson analyzed statutes that regulated the tobacco industry, the Court inferred from several new laws and later legislative activity that addressed narrower issues of tobacco marketing that Congress had revealed an intent to prohibit any FDA regulation of tobacco. ${ }^{167}$ As the dissent pointed out, with the exception of one statute specifically declining to change the status quo regarding potential FDA authority to regulate tobacco, the texts of these later laws nowhere stated anything about FDA powers under the 1938 FDCA. ${ }^{168}$ The Court nevertheless combined textual analysis and the absence of explicitly empowering language in the FDCA, the existence of subsequent tobacco laws and the FDA's earlier decisions not to regulate tobacco, and abundant analysis of various political actors' views regarding FDA authority, to reach the conclusion that the FDA lacked jurisdiction over tobacco.

While Brown $\mathcal{E}^{2}$ Williamson presented a close question under any approach to statutory interpretation, the majority's heavy weighting of more limited legislative forays into tobacco regulation as revealing an implicit prohibition of FDA jurisdiction create, once again, odd incentives for legislators. Legislators desiring to regulate a source of harm in specific, more narrowly targeted laws risk disempowering agencies that already have latent regulatory authority. In Gebser, Bennett, or Brown $\mathcal{E}^{\circ}$ Williamson, a different approach to statutory interpretation that emphasized attention to each statute's text and vertical history would likely have led to different outcomes. The Court's interstatutory cross-referencing in each case gave the Court a strengthened basis to reject conclusions that appeared most logical based on the primary statute's text and vertical history alone. ${ }^{169}$

Whi For example, Justice O'Connor's inferences in Gebser from a later civil rights statute's specificity were key to how the Court circumscribed the earlier law's damages cause of action despite different conclusions that would likely have been reached in the absence of the later S2 referent. See supra notes 101-14 and accompanying text (discussing Gebser). The use of the one-Congress fiction in Bennett similarly manifested inferences drawn about the breadth of an earlier statute by looking at a later statute's slightly more specific language. See supra Part I.B.1 (providing an overview of the Supreme Court's comparison of similar language in multiple statutes).

${ }^{167}$ See supra Part I.B.3 (discussing the Brown E Tilliamson decision).

${ }^{160}$ See supra notes 98-100 and accompanying text (discussing Justice Breyer's dissenting opinion in Brown E Williamson).

${ }^{169}$ For a discussion of "vertical" context or history versus "horizontal" approaches, see supra notes $61-66$ and accompanying text. 


\section{JUSTIFICATIONS FOR THE ONE-CONGRESS FICTION?}

Justices engaging in the one-Congress fiction have infrequently articulated an explanation for this interpretive practice. Justice Scalia has mentioned a need for the Court to make sense of the corpus juris, but neither he nor other justices have provided much additional explanation. This Part explores this justification, plus a few others, but then tests this practice and these justifications against instrumental and normative arguments underlying textualist modes of interpretation. While the one-Congress fiction technique has historical antecedents and is not utterly illogical, its use appears inconsistent with several of the textualists' central goals and claims. This critique of the one-Congress fiction further reveals the weak underpinnings of several of textualism's empirical and normative roots.

\section{A. Justifications and Interpretive Precedents}

If one assumes that the legislative process has the potential to produce logical and coherent outcomes, then predictable interpretive methods are essential to effective statutory drafting. Evaluating the one-Congress fiction in light of the existence of other frequently utilized.interpretive techniques and canons is thus of critical importance. If this interpretive technique falls within accepted approaches to statutory interpretation, or constitutes an "interpretive convention" anticipated by players in the legislative process, then use of such a technique may be an important means to ensure the legitimacy and rationality of the legislative process and statutory interpretation. ${ }^{170}$ As observed by Professor Raz, and more recently expounded upon by Professor Manning, given the difficulty (or impossibility) of locating an actual legislative "intent" from a collective body that often fails to anticipate tough interpretive questions, positivist theories of interpretation embrace the idea that legislators must be able to assume that "statutes... will be interpreted according to accepted interpretive conventions." This desire for interpretive conventions that can be anticipated and shared by drafters and interpreters of the law is com-

${ }^{170}$ The British legal system, for example, appears to make a more concerted effort to develop and utilize shared drafting and interpretive conventions. See ATIYAH \& SUMMERS, supra note 121, at 96-114, 384-407.

${ }^{171}$ John F. Manning, Textualism as a Nondelegation Doctrine, 97 COLUM. L. REV. 673, 690-92 (1997) (discussing and refining observations made in Joseph Raz, Intention in Interpretation, in THE AUTONOMY OF LAW 249, 258-69 (Robert P. George ed., 1996)). 
mon to textualists and positive political theorists alike. ${ }^{172}$ Laws must be "decoded" according to "interpretive conventions prevailing in the relevant legal culture."173 Interstatutory comparisons of isolated provisions, or the "one-Congress fiction," has superficial similarity to commonly applied interpretive conventions, but in the final analysis, it is significantly distinguishable from, and lacks the underlying justifications for, its two most analogous interpretive precedents.

\section{Making Sense of the Corpus Juris and the In Pari Materia Canon}

As articulated by Justice Scalia in Casey ${ }^{174}$ and in his recent essay on interpretation, ${ }^{175}$ one justification for making interstatutory comparisons in construing a debated primary statute provision is to make sense of the overall body of statutory law. As articulated, Justice Scalia sees this task as one for the courts, repeatedly referring in his recent essay on interpretation to what "we" and "judicial opinions in my court and others" do and should do in interpreting statutes. ${ }^{176}$ A statute must, in Justice Scalia's words, be understood in a manner "most compatible with the surrounding body of law into which the provision must be integrated-a compatibility which, by a benign fiction, we assume Congress always has in mind."177 Here, his explanation appears to be that courts, or at least the Supreme Court, should take the opportunity in cases to ensure some coherence across the whole body of law, regardless of whether Congress had such an intent.

In one respect, this goal of creating legal coherence makes eminent sense, especially if one imagines an opposite approach that ignored other statutes' language choices and their implications. Were the Court to look at every statutory dispute anew, without even look-

${ }^{172}$ See McNollgast, supra note 124, at 715-16 (noting that an internally inconsistent and unpredictable set of interpretive canons will disrupt an enacting coalition's "policy bargain"). Public choice theorists question the logic of expecting any legislative coherence. See supra note 122 (citing to public choice theorists and describing central public choice tenets).

${ }^{173}$ Manning, supra note 171, at 692.

${ }^{174}$ See supra notes 69-73 and accompanying text (providing Justice Scalia's explanation for his interstatutory references in Casey).

${ }^{175}$ SCALIA, supra note 4.

${ }^{17 i}$ See, e.g., id. at 16 (using such terminology).

${ }^{177}$ Green v. Bock Laundry Machine Co., 490 U.S. 504, 528 (1989) (Scalia, J., concurring). Justice Scalia frequently makes such reference both to interrelated provisions within a statutory scheme and to other statutes' usage. See Eskridge, supra note 9, at 661 ("Justice Scalia will consider how the word or phrase is used elsewhere in the same statute, or how it is used in other statutes."). 
ing at other statutes or, perhaps more importantly, the Court's own handiwork in interpreting the laws, an incoherent line of case law could be created. However, the seemingly laudable task of establishing coherence in the law poses several substantial risks, even when evaluated against usually articulated justifications for textualist modes of interpretation, as discussed below in Part III.B.

Nevertheless, the one-Congress fiction technique has one obvious interpretive precedent. While the technique has not often been explained as rooted in any particular canon of statutory interpretation, the concern with avoiding interpretive incoherence in the case law and the embrace of interstatutory comparison share many attributes with the in pari materia doctrine. This approach to statutory interpretation is invoked when statutes share a common subject matter, employ similar language, or directly refer to one another. Under such circumstances, the judiciary "will presumptively interpret the former law consistently with the other and will rely on prior interpretations of one to interpret the other." ${ }^{178}$ In several of his opinions, Justice Scalia has cross-referenced different statutes' provisions with explicit reference to the in pari materia doctrine. Consistent with the usual application of this doctrine, however, his analysis has included not just isolated statutory language, but case law surrounding the referent provision. ${ }^{179}$ In other cases, however, Justice Scalia has shunned such an interstatutory comparison due to the different fields covered by the suggested primary and referent statutes and to the lack of textual indication that the two laws were intended to be read together. ${ }^{180}$ How

${ }^{178}$ William N. Eskridge, Jr., Public Values in Statutory Interpretation, 137 U. PA. L. REv. 1007, 1039 (1989); see also Marc A. Kushner, The Legality of Race-Conscious Access Quotas Under the Fair Housing Act of 1968, 9 CARDOZO L. REV. 1053, 1080-81 (1988) (discussing the in pari materia doctrine with reference to civil rights statutes); Michael $\mathrm{E}$. Solimine, Removal, Remands, and Reforming Federal Appellate Review, 58 MO. L. REV. 287, 299 (1993) (discussing the in pari materia doctrine with reference to Thermtron Products, Inc. v. Hermansdorfer, 423 U.S. 336 (1976)).

${ }^{179}$ For example, writing for the majority in Pierce $v$. Underwood, Justice Scalia discerned the meaning of the phrase "substantially justified" found in the Equal Access to Justice Act in part by looking to the meaning of "substantial" garnered from the case law surrounding the APA and Rule 37 of the Federal Rules of Civil Procedure. 487 U.S. 552, 564-65 (1988). In Kungys $v$. United States, he arrived at the meaning of the word "material" in the Immigration and Nationality Act of 1952 by turning to its usage in criminal statutes. 485 U.S. 759, 769-70 (1988).

${ }_{180}$ Justice Scalia, in Fort Stewart School v. Federal Labor Relations Authority, refused to compare the language used in the Federal Service Labor-Management Relations Statute ("FSLMRS") to that of the National Labor Relations Act ("NLRA"), arguing that the in pari materia rule did not apply because the fields of employment covered by the two statutes differed and the FSLMRS did not state or imply that it was to be read in light of the NLRA. 495 U.S. 641, 647-48 (1990). 
those who make use of the one-Congress fiction or adhere to the in pari materia doctrine decide which provisions are appropriate for cross-reference inferences is not clear. ${ }^{181}$ Furthermore, in Bennett and Casey, as well as in the few additional one-Congress fiction cases discussed above, the Court sometimes utterly fails even to examine other data about the statutory referent, failing particularly to consider case or agency interpretations of the referent provision.

Much as Justices Stevens and Scalia are today divided on application of the one-Congress fiction, the Court has, in the past, divided on the appropriateness of the application of the in pari materia doctrine. For example, Justice Frankfurter in United States v. Monia gave a forceful dissent regarding the in pari materia canon. ${ }^{182}$ He rejected the wisdom of the majority's interstatutory comparison of language, stating: "The meaning of such a statute cannot be gained by confining inquiry within its four corners. Only the historic process of which such legislation is an incomplete fragment-that to which it gave rise as well as that which gave rise to it-can yield its true meaning., ${ }^{183}$ He then went on to compare the Sherman Act with the other statutes used by the majority, and concluded that although the language differed, the purpose behind the statutes was the same. ${ }^{184}$

${ }^{1 \times 1}$ As explored further below, Justice Scalia clearly is willing to employ the in pari materia rule for interstatutory comparisons, but he may forego doing so if he believes the statutes in question are too dissimilar or do not implicate each other in some manner. What makes two statutes dissimilar is contestable, though, and Justice Scalia's reasoning for precluding the use of in pari materia in Fort Stewart Schoot-divergent fields of operation and no evidence that one of the statutes was meant to be read in conjunction with the other-seems equally applicable to Pierce, Kungys, Casey, and Bennett. For a more detailed discussion of these cases, see supra Parts I.B.1., I.B.2., and I.B.4.

1*2 317 U.S. 424, 431-47 (1943). The majority had ruled that a party who testifies under oath concerning a particular offense obtains immunity under the Sherman Act irrespective of whether that party asserted his or her privilege against selfincrimination. Id. at 425-31. The Court reached this conclusion by comparing the Sherman Act, which said nothing about an assertion against self-incrimination, with various other statutes that required such an assertion before immunity could be granted. Id. at 429-30. Justice Frankfurter rejected this methodology, asserting that "[t]he notion that because the words of a statute are plain, its meaning is also plain, is merely pernicious oversimplification." Id. at 431 .

Iss. at 432.

${ }^{1 \times 4}$ See id. at 444 . Frankfurter wrote:

[T] here is a total absence of any indication anywhere that any Congressman had any notion that the enforcement of the Motor Carrier Act of 1935, the Industrial Alcohol Act, or the Fair Labor Standards Act of 1938, called for a different treatment of witnesses in proceedings ... under the other fourteen Acts.

Id. He criticized the majority approach for its implicit assumption that all of the stat- 
Justice Stevens also has objected to an overly broad use of in pari materia in a case illustrating the sometimes blurred line between interstatutory comparisons and examinations of provisions within the same act under the expressio unius canon. ${ }^{185}$ In Sorenson v. Secretary of the Treasury, the issue was whether a refund obtained through the earned income tax credit could be seized by a state seeking recoupment for past-due child support payments assigned to the state. ${ }^{186}$ The Court's examination of two provisions codified in the same act, but enacted at different times, informed the Court's conclusion about the disputed provision's meaning. ${ }^{187}$ The Court invoked the rule that "identical words used in different parts of the same act are intended to have the same meaning." 188 Justice Stevens, in his dissent, rejected this comparison of provisions enacted by different Congresses based on his view that, in the absence of actual knowledge of these provisions' proximity and overlap, interpretive inferences were inappropriate. ${ }^{189}$

utes were written by a "single draftsman." Id. In his view, such an assumption was completely unrealistic:

If a single draftsman had drafted each of these provisions in all seventeen statutes, there might be some reason for believing that the difference in language reflected a difference in meaning. But it is common knowledge that these measures are frequently drawn, at least in the first instance, by specialists (perhaps connected with interested government departments) in the various fields. Provisions in different measures dealing with the same procedural Id. problem not unnaturally, therefore, lack uniformity of phrasing.

${ }^{185}$ For greater discussion of the similarities and differences between the oneCongress fiction and the expressio unius canon, see infra Part III.A.2.

${ }^{186} 475$ U.S. 851 (1986).

187 The Court's determination turned on whether the earned-income tax credit constituted an "overpayment" for the purposes of the federal intercept law, which allowed states to seize federal tax refunds under certain circumstances. The federal intercept statute, which referred to "overpayments," was enacted as part of the Omnibus Budget Reconciliation Act of 1981 ("OBRA"). "Congress had previously expressly defined an excess earned-income credit as an 'overpayment' in $\$ 6401$ (b) of the Internal Revenue Code-the section immediately preceding the section to which Congress added the intercept provision." Id. at 864 . Hence, though the two sections were adjacent to one another, they had been enacted at different times. This case clearly demonstrates the frequently blurred line between contexts in which the more defensible expressio unius doctrine is applied to construe different provisions in the same act, and contexts where the courts are dealing with two different laws. See infra Part III.A.2 (comparing and contrasting the one-Congress fiction and the expressio unius canon); see also Vt. Agency of Natural Res. v. United States ex rel. Stevens, $120 \mathrm{~S}$. Ct. 1858, 1870 \& n.17 (2000) (construing whistleblower statutes as "sister schemes"); id. at 1877 (Stevens, J., dissenting) (viewing the two laws as "separate" and asserting they should not have bearing on each other).

${ }^{188}$ Sorenson, 475 U.S. at 860 (quoting Helvering v. Stockholms Enskilda Bank, 293 U.S. 84,87 (1934)).

${ }^{189}$ Id. at 867 . 
In his view, it was ridiculous "to assume that a substantial number of legislators were sufficiently familiar with OBRA to realize that somewhere in that vast piece of hurriedly enacted legislation there was a provision that changed the 6-year-old Earned Income Credit Program." "ing

Analysis of cases applying the in pari materia doctrine indicates that the goal is to ensure that courts engage in consistent modes of interpretation. It assumes something akin to a court, Congress, and agency conversation, where each is aware of the interpretations and acts of the other: "[W] $]$ here ... Congress adopts a new law incorporating sections of a prior law, Congress normally can be presumed to have had knowledge of the interpretation given to the incorporated law, at least insofar as it affects the new statute." ${ }^{191}$ Where a Court makes interstatutory comparisons of text alone, however, without regard to case exegesis, agency interpretations, legislative development, or history of the referents, its practice appears inconsistent with the usual application of the in pari materia doctrine. The in pari materia rule hence shares several key attributes with the one-Congress fiction technique, but it generally involves a more probing analysis of compared provisions' contexts and, in particular, their past judicial interpretations. The in pari materia approach thus is at least a logical doctrine (even if aspirational) that at its core constrains courts and forewarns legislators that, where authoritative interpretations by the courts of earlier laws exist, the courts are expected to engage in consistent interpretive approaches to later laws. Interpretation by means of the one-Congress fiction, in contrast, seldom includes attention to courts' earlier statutory interpretations, focusing instead on statute-to-statute comparisons.

\section{The One-Congress Fiction and the Expressio Unius Canon Compared}

Both justices and scholars occasionally speak of intrastatutory and interstatutory linguistic comparisons in the same context, but the two

${ }^{10 *}$ Id. He noted that although "the Court's reading of the statutory language is faithful to its grammar," it probably did not reflect congressional intent. Id. Thus, Justice Stevens refused to apply the in pari materia rule in a manner that he felt violated congressional intentions and that took a naive view towards the interconnection among various provisions.

${ }^{191}$ Lorillard v. Pons, 434 U.S. 575, 581 (1978), cited and discussed in Eskridge, supra note 178 , at $1039 \& \mathrm{n} .125$ (explaining interstatutory comparisons but without explicit use of term in pari materia). 
practices are quite different in implication and in their reception by the Supreme Court. ${ }^{192}$ The justification for drawing inferences from linguistic similarities and differences within the same statute was articulated well by Justice Scalia in 1988:

Statutory construction, however, is a holistic endeavor. A provision that may seem ambiguous in isolation is often clarified by the remainder of the statutory scheme-because the same terminology is used elsewhere in a context that makes its meaning clear... or because only one of the permissible meanings produces a substantive effect that is compatible with the rest of the law.

Such an assumption of internal consistency and inference-drawing from comparisons of language within the same statute is well established under the expressio unius est exclusio alterius canon. This canon of construction assumes that "inclusion of one thing indicates exclusion of the other." ${ }^{194}$ Like the one-Congress fiction, this canon makes greatest sense if the starting premise is something close to an omniscient legislative drafter. Given the reality of a Congress that often is sloppy, however, critics question whether significant interpretive inferences should be drawn from the presence or absence of provisions within the same law. ${ }^{195}$ Nevertheless, this interpretive practice has

${ }^{192}$ See Schacter, supra note 8 , at 31 (discussing these two practices in her examination of the Court's "common law originalism," but questioning whether interstatutory comparisons are justifiable); see also SCALIA, supra note 4, at 16-17 (calling for courts to interpret laws to make them "not only internally consistent, but also compatible with previously enacted laws"). Professor Amar's recent discussion of constitutional "intratextualism," particularly his critique of "holistic textualism," shares attributes with this Article's critique of the one-Congress fiction. See Akhil Reed Amar, Intratextualism, 112 HARV. L. REV. 747, 798 (1999) (explaining the difficulty of examining "an almost infinite number of interclausal comparisons").

${ }^{193}$ United Savings Ass'n of Texas v. Timbers of Inwood Forest Ass'n, 484 U.S. 365, 371 (1988) (citations omitted). Abiding by this principle, Justice Scalia compared the language and structure of various provisions in the Bankruptcy Code to discern the meaning of "interest in property" in $\$ 362$ (d) (1) of the Code. See id. at 371-79 (setting forth the Court's analysis); see also Daniel A. Farber, The Inevitability of Practical Reason: Statutes, Formalism, and the Rule of Law, 45 VAND. L. REV. 533, 545 (1988) (pointing out that even when analyzing a statute merely with reference to statutory language, judges still have substantial discretion in deciding "how big a chunk of text should be interpreted under the plain meaning rule").

${ }^{194}$ ESKRIDGE \& FRICKEY, supra note 9, at 638.

195 See id. at 639 (citing criticisms by courts and by Judge Posner of strong reliance on this canon). Popkin asserts that divergent language may simply reflect the constraints placed on the hectic life of legislators, who constantly must shift their attention based on newly-perceived problems. See Popkin, supra note 6, at 1149 ("Even within a single statute, the idea that express references exclude what is not specifically stated is foreign to the political reality of a busy legislature attending to problems called to its attention."). 
been embraced by numerous Supreme Court justices, although the justices have unsurprisingly drawn different inferences from particular intrastatutory linguistic comparisons. ${ }^{196}$

Such an approach is also consistent with what Professor Schacter refers to as a "disciplinarian" approach to statutory interpretation. ${ }^{197}$ Her theory, amply demonstrated with references to both cases and theories of legislative process, is that, due to the perceptions of some judges that the legislative process is prone to public choice dysfunction or simple sloppiness, courts will interpret laws with an assumption of rigor and thoroughness. Like a parent assuming that high expectations for children will encourage high achievement, disciplinary judges assume that legislators confronted by courts expecting excellence will improve their work. Such a disciplined legislature will, under this theory and normative argument, rigorously ensure that similar provisions in the same statute dovetail so that interpretive inferences can appropriately be made by courts. Legislators will be forced to "embrace, not evade, their obligation to make hard policy choices." This optimistic premise about the power of courts to discipline the legislature assumes that legislative rationality is a possibility.

The expressio unius canon is hence rooted in a logical, perhaps aspirational, premise finding support in a wide range of schools of statutory interpretation. When one legislature enacts a single law, or even when two different Congresses work on the same law, drafters are reasonably expected to look at how a single law works as a whole. In this setting, legislative partisans can anticipate what statutory provisions will be read together. One need not embrace public choice premises or a disciplinary approach to statutory interpretation to justify looking

1"*i, For a cross section of cases in which justices have either explicitly embraced the application of the expressio unius canon or engaged in such an interpretive technique, see ESKRIDGE \& FRICKEY, supra note 9, at 639 \& n.3 (citing, among other cases, Key Tronic Corp. v. United States, 511 U.S. 809 (1994) (Stevens, J.); United States v. Smith, 499 U.S. 160 (1991) (Marshall, J.); Chan v. Korean Air Lines, Ltd., 490 U.S. 122 (1989) (Scalia, J.); Miss. Band of Choctaw Indians v. Holyfield, 490 U.S. 30, $46-47$ \& n.22 (1989) (Brennan, J.); Mackey v. Lanier Collections Agency and Serv., 486 U.S. 825, 836-37 (1988) (White, J.)).

${ }^{1} \cdot 77$ See Schacter, supra note 35 , at $636-46$ (finding a prevalent judicial view that "the courts must discipline the political process through deliberately crafted interpretive rules").

Id. at 645 .

${ }^{1+4}$ For a strong contrary argument that embraces public choice suppositions about irrational legislative outcomes and criticizes as unsound judicial attempts to improve the legislative process, see Shepsle, supra note 62. 
at a single act's similar provisions and drawing conclusions from their language choices. Hart and Sacks suggested in their foundational Legal Process text that statutory interpreters should assume that legislators, in drafting laws, engage in purposive activities and therefore interpret laws in that light. ${ }^{200}$ To hold drafters to a presumption of internal statutory coherence is reasonable from a wide range of approaches to statutory interpretation, from that of Justice Scalia to the far more purpose-oriented approach espoused by Hart and Sacks.

The one-Congress fiction approach, however, is analytically distinct from application of the expressio unius canon. In the context of interstatutory cross-referencing, the two compared laws are never the work product of the same legislative coalitions, nor are they drawn from two or more different legislative amendments of the same statute. ${ }^{201}$ While expressio unius undoubtedly rests on an assumption of thoroughness that is often not borne out in reality, there is at least an actual enacting coalition that knows the provisions that will share space in the same statute. Such an enacting or amending coalition can also reasonably be assumed to share the same expectations about "interpretive conventions" due to the shared timing of legislative activity. ${ }^{202}$ Even where there are multiple statutory amendments, at least the final amending coalition has an opportunity to ensure that the laws' structures and language choices work together. ${ }^{203}$ The expressio unius canon of interpretation is thus aspirational, but it does not rest on counterfactual assumptions of omniscient legislators able to know both the universe of similar provisions in other statutes and which provisions and linguistic differences would be viewed as significant by a reviewing court. ${ }^{204}$ No opportunity for coherent dovetailing of pri-

${ }^{200}$ HENRY M. HAART, JR. \& ALBERT M. SACKS, THE LEGAL PROCESS: BASIC PROBLEMS IN THE MAKING AND APPLICATION OF LAW 1374 (William N. Eskridge, Jr. \& Phillip P. Frickey eds., 1994); see supra note 137 and accompanying text (discussing assumption of "purposive" activities and distinguishing such an assumption from interpretive methods seeking merely to further gleaned statutory purposes).

${ }^{201}$ Interest groups acting together in coalitions regarding a statutory proposal "propel the game forward." William N. Eskridge, Jr., The Judicial Review Game, 88 NW. U. L. REV. 382, 385 (1993).

${ }^{202}$ For a discussion of how a shared expectation about interpretive conventions is central to positivist theories of statutory interpretations, see Manning, supra note 171; Raz, supra note 171.

${ }^{203}$ See supra note 187 (discussing disagreement on the Court in Vermont Agency regarding whether two whistleblower laws should be viewed as "sister schemes" and construed in light of each other).

${ }_{204}$ In contrast to the application of the expressio unius canon, the one-Congress fiction approach poses another risk identified by Professor Popkin. What he calls the "super-text" approach may intrude upon the expectation interests of legislators. Pop- 
mary-referent provisions ever exists where courts draw interpretive significance from two different statutes' language choices. Thus, despite the superficial similarity of these two practices, they are actually significantly different. The expressio unius canon can logically be questioned, but it is far more justifiable than the one-Congress fiction.

\section{The Search for Objective Meaning}

A third justification for the one-Congress fiction is textualists' search for rules of interpretation that rest on objective, common sources for discerning statutory meaning. Under this view, interstatutory comparisons are similar to several justices' preference for examining dictionary definitions rather than historical context or materials reflecting at least some legislators' statements about actual linguistic intent. $^{245}$ If the Court is going to interpret laws according to their "plain meaning," using dictionaries and statutes to help discern that meaning, then interstatutory references are sensible. ${ }^{206}$ Professor Schauer suggests that the use of common sources of meaning functions as a "second-best coordinating device for multiple decisionmakers attempting to reach some methodological consensus. ${ }^{207}$ Reliance on dictionaries rather than the legislative or political history of a statute has been strongly criticized. ${ }^{208}$ Furthermore, as suggested by Judge Posner, the veneer of plain meaning neutrality and its apparent "mechanical" application "conceal... the extent to which the judge is

kin, supra note 6 , at 1149 . Because different provisions in the United States Code are inserted at different times, Congress "may or may not have meant the surrounding text to be part of an integrated document." Id. at 1150. This Article agrees with Popkin's critique, but goes further in questioning both the soundness of the practice's underlying assumptions and, as a normative matter, the wisdom of expecting courts to engage in the one-Congress fiction.

Compare MCI Telecomms. Corp. v. AT\&T, 512 U.S. 218, 225-29 (1994) (Scalia, J.) (scrutinizing extensively the dictionary usages of "modify"), with id. at 240-45 (Stevens, J., dissenting) (criticizing the reliance on dictionaries as "no substitute for close analy'sis of what words mean as used in a particular statutory context"). For academic critiques of the Court's recent substantial reliance on dictionaries, see, for example, A. Raymond Randolph, Dictionaries, Plain Meaning, and Context in Statutory Interpretation, 17 HARV. J.L. \& PUB. POL'Y 71 (1994); Note, Looking It Up: Dictionaries and Statutory Interpretation, 107 HARV. L. REV. 1437 (1994).

See, e.g., Karkkainen, supra note 9, at 408 (discussing the ways in which Justice Scalia, while arguing the primacy of text, refers to "external contexts" to derive statutory meaning).

:4177 Frederick Schauer, Statutory Construction and the Coordinating Function of Plain Meaning, 1990 SUP. CT. REV. 231, 232.

For examples of such critiques, see supra note 205. See also Pierce, supra note 9 , at 762-63 (criticizing the disruptive results of textualists' exclusive reliance on "plain meaning" and dictionaries, without considering legislative or implementation history). 
making new law in the guise of interpreting a statute." ${ }^{209}$ Once one assumes genuine textual ambiguity, then a plain meaning approach is insufficient. The question then becomes how litigants and courts will resolve the statutory conundrum. ${ }^{210}$ As shown further below, despite its textualist pedigree, the one-Congress fiction suffers from many of the infirmities textualists emphasize regarding more context-based modes of interpretation. The following sections delve further into arguments for and against the one-Congress fiction interpretive practice and offer additional analysis of textualism's underpinnings and rationales in light of this critique of the one-Congress fiction.

\section{B. The One-Congress Fiction Practice and Textualism's Justifications}

The one-Congress fiction is undoubtedly an interpretive practice that is rooted in textualism. Statutory texts are compared to other statutory texts, with courts drawing inferences from such comparisons. While justices embracing this practice have on a few occasions looked at more than mere text-to-text parallels, sometimes examining linked cases and legislative history, the analysis is more often of text alone. ${ }^{211}$ It also happens that the justices most frequently utilizing this interpretive ploy are self-avowed textualists. Justice Scalia, in particular, has been vocal in articulating his empirical and normative justifications for textualist interpretive approaches. ${ }^{212}$ The now extensive debates

${ }^{209}$ Richard Posner, Statutory Interpretation-in the Classroom and Courtroom, $50 \mathrm{U}$. CHI. L. REV. 800, 816-17, 822 (1983) (quoted and discussed in Karkkainen, supra note 9, at 452-54); see also Farber, supra note 193, at 548 ("If the issue, however, is not the dictionary meaning of a particular clause, but the interpretation that produces the best 'fit' with a complex statute, the judge's decision involves sufficient intangibles to leave the door open to such 'subjective' factors [as the judge's sense of fairness, justice, or social welfare].").

${ }^{210}$ See Funk, supra note 9 , at 845-46. tion).

See supra Part I (reviewing cases in which the Court used the one-Congress fic-

${ }^{212}$ Another preeminent textualist is Judge Easterbrook, but due to the different roots of his advocacy of textualism, he would likely find the one-Congress fiction inappropriate. Justice Scalia focuses on legislator and staff manipulation of the historycreation process, as well as ends-oriented judicial decisionmaking. See SCALIA, supra note 4, at 29-37 (discussing the recent abuses of using legislative history as an interpretive tool). Judge Easterbrook, in contrast, focuses on the impossibility of locating intent in a collective entity, as does Professor Shepsle. See Easterbrook, supra note 72, at 547 ('Because legislatures comprise many members, they do not have 'intents' or 'designs,' hidden yet discoverable."); Shepsle, supra note 62, at 249 (contending that Arrow's impossibility theorem necessarily implies that legislative intent has no meaning). Judge Easterbrook has made clear that he does not believe one can appropriately discern meaning through statute-to-statute comparisons. See Easterbrook, supra note 72, at 547 ("It is ... impossible to reason from one statute to another ...."). 
over textualist versus originalist versus purposive versus dynamic modes of interpretation will certainly not be resolved by this Article. This section offers a more modest endeavor. The implications of interpretation relying on the one-Congress fiction are analyzed and tested against the main articulated justifications for textualist interpretation. This comparative analysis reveals that interstatutory comparisons, while text-based, are largely inconsistent with the justifications for textualism. Furthermore, this analysis of the one-Congress fiction also reveals the weak underpinnings of textualism and calls into question some of its supporters' broader claims about textualism's merits. $^{215}$

Textualist interpretive modes are often justified by way of contrast to interpretive methods relying on the examination of legislator or committee statements about the meaning of disputed provisions. The first rationale is rooted in distrust of the legislative process and public choice concerns about politics. Judges should rely only on the statutory text rather than on nonlegislative statements to ensure that legislators legislate through the only means sanctioned by the Constitution-through bicameral votes and presentment to the President. ${ }^{214}$ Such a text-only approach can be rooted in the reality of the absence of a unified "intent" of a collective body, in concerns about legislative "self-delegation," dodging, and manipulative uses of legislative history by legislators who are unable or unwilling to achieve their goals in actual laws.

The second main justification is rooted in distrust of judges. If judges can resolve tough interpretive questions with resort to nontextual sources, particularly legislator-created legislative history, they will, in the oft-quoted words of Judge Harold Leventhal, manipulate that process like "looking over a crowd and picking out your friends. ${ }^{, 216}$ As stated by Justice Scalia in his recent essay, $A$ Matter of In-

${ }^{213}$ While this discussion alludes to criticisms of textualism, this section focuses primarily on textualists' own articulated rationales.

${ }^{214}$ See, e.g., SCAlIA, supra note 4, at $34-36$ (emphasizing the importance of the formal constitutional channels of legislative enactment, bicameralism, and presentment, to prevent lawmaking power from resting in the hands of committees or several legislators); Manning, supra note 171, at 690-91 (characterizing textualism as rooted in a prohibition against "legislative self-delegation" that occurs when legislators can modify a statute's meaning outside of the constitutionally mandated process).

${ }^{2135}$ This more recently articulated explanation for textualism is found in Manning, supra note 171.

211: For discussions on the use of legislative history quoting Judge Leventhal's statement, see Stephen Breyer, On the Uses of Legislative History in Interpreting Statutes, 65 S. CAL. L. REV. 845, 846, 861-62 (1992); Wald, supra note 11, at 214-16. 
terpretation, "the practical threat is that, under the guise or even the selfdelusion of pursuing unexpressed legislative intents, common-law judges will in fact pursue their own objectives and desires, extending their lawmaking proclivities from the common law to the statutory field. ${ }^{217}$ Textualist modes of interpretation rooted in examination of a single statute's text and structure do, indeed, further some of these textualist rationales, even if other competing concerns lead some scholars and judges to reject excessive reliance on text-limited techniques. ${ }^{218}$ Allowing or encouraging judges to extend that reliance on statutory texts to inference-drawing from comparisons of two different laws, however, poses substantial risks of judicial abuse and also fails to further several of the "legislative excellence" goals of textualist analysis.

\section{Promoting Legislative Excellence and Interstatutory Comparisons}

Justice Scalia, Judge Easterbrook, Professor Manning, and other advocates of textualism suggest that judges' use of legislative history encourages inappropriate political behavior. ${ }^{219}$ If legislators can insert comments in debates and committee reports, they will do so to favor interest groups, yet such comments will appear in a context less visible to all players in the legislative process. ${ }^{220}$ Legislators will, under this argument, stuff the legislative history with hooks for subsequent favorable statutory interpretations by the courts and, concomitantly, worry less about flagging those particular legislative goals in actual statutory language. $^{221}$ If courts examine legislative history, they reward this kind

${ }^{217}$ SCALIA, supra note 4, at 17-18. For further exploration of textualism as a means to constrain overreaching judges, but with a focus on constitutional decisionmaking, see Michael J. Gerhardt, A Tale of Two Textualists: A Critical Comparison of Justices Black and Scalia, 74 B.U. L. REV. 25 (1994).

${ }^{218}$ See, e.g., Strauss, supra note 9 (arguing that textualism frees judges to pursue their own political agendas even if it acts to constrain some abuses of using legislative history to interpret statutes).

${ }^{219}$ See supra notes 211-15 and accompanying text (highlighting internal inconsistencies between textualism's tenets and the one-Congress fiction).

${ }^{220}$ See Peter Strauss, Legislative Theory and the Rule of Law: Some Comments on Rubin, 89 COLUM. L. REV. 427,436 (1989) (stating that "any realistic reader understands" that references to what a committee "intends ... are ordinarily written by staff, often at the behest of lobbyists, not by members of Congress themselves") quoted and discussed in Mayton, supra note 140 , at 114 n.5.

${ }_{221}$ See SCALIA, supra note 4, at 34-35 (contending that because of the Court's reliance on legislative history, the primary purpose of floor debates and committee reports is to affect the courts rather than inform the Congress); Manning, supra note 171, at 
of behavior and undercut the Constitution's designated legislative process.

Relatedly, given public-choice and game-theory insights about vote cycling and the absence of any discernible "intent" of a collective body, textualists argue that courts should not give interpretive significance to a single legislator's or committee's statements on a tough interpretive issue. ${ }^{222}$ Silent acquiescence or unexplained floor votes are equally important to the enactment of statutes, but they are given little or no weight if it is only explanations of advocates that sway results in statutory interpretation battles. ${ }^{223}$ Even for proponents of scrutiny of legislative history, such as the McNollgast trio, difficult questions arise regarding which legislators' statements or views (perhaps unexpressed) deserve interpretive weight. Should courts give weight to a bill's proponents (who likely would prefer a broader statutory result), a bill's swing voters, or the President due to his control of "veto gates" and relatively greater individual importance to the enacted statute's passage? ? $^{224}$

Shunning, or at least de-emphasizing, judicial reliance on legislative history is arguably consistent with these stated ends, even if it is an incomplete justification for textualism. Does application of the oneCongress fiction further these ends? General shunning of selfreferential legislative history in all contexts, whether a court is examining one primary statute or multiple statutory referents, continues to serve the goal of discouraging legislator reliance on less visible statements to win political battles not clearly resolved in a statute itself. ${ }^{225}$ Where courts examine two laws and draw interpretive inferences, however, they cannot explain that analysis with reference to what Professor Manning, a defender of textualism, refers to as the legislative supremacy underpinnings of textualist modes of interpretation: "If statutory interpretation bore no relation to the law the legislator intended to make, it would mean very little to say that ours is a system

693-94 ("Congress may well assign explanatory authority to its own agents with the implicit understanding that their exposition will influence courts.").

${ }_{222}$ See Shepsle, supra note 62, at 240-50 (developing a public choice model for the workings of legislatures derived from Arrow's impossibility theorem and concluding that legislative intent is a meaningless notion).

${ }^{223}$ See, e.g., McNollgast, supra note 124 (exploring the significance of veto gates and suggesting that investigating legislative history can yield important information about "whose preferences were most consequential" to the enacting coalition).

224 Id. at 720 .

${ }^{22-}$ See supra note 14 and accompanying text (explaining concept of "selfreferential" legislative history). 
marked, within constitutional boundaries, by legislative supremacy."226

No realist or positivist theory of interpretation can expect actual or even ideal legislators to have the several layers of knowledge necessary if one is to root the one-Congress fiction in conceptions of legislative supremacy and a search for meaning based on shared "interpretive conventions." In contrast to the analysis of a single law's meaning, interpretive inferences from interstatutory comparison resting on some anthropomorphized or single omniscient and consistent drafter conception of Congress and intended meaning would require at least one, if not both, of the enacting Congresses to have the following highly unlikely layers of knowledge. They must: (1) know what laws will be the subject of interstatutory comparison, (2) know what linguistic consistency or inconsistency will be found significant by a reviewing court, and (3) share a common set of "interpretive conventions," even with laws enacted at different times and often in unrelated fields of regulation that have their own set of assumptions and history. Possession of these layers of knowledge is particularly unlikely because the world of legislation is not a closed system where only legislators control statutory meaning; as discussed above in Part II, court and agency interpretations, as well as changing political environments, lead legislators and affected coalitions to seek statutory change. ${ }^{227}$ These assumptions, necessary to make sense of the oneCongress fiction, have utterly no basis in any positivist or realist conception of the statutory process.

Furthermore, even if the goal is to encourage legislative excellence in drafting and more thorough research into the implications of language choice, the three necessary layers of knowledge suggested above are simply beyond any individual's or collective entity's capabilities. If, however, courts engage in the one-Congress fiction only where there is indication in the text itself, in a statute's historical context or perhaps even in legislative history, that some knowledge of two or more laws' interconnection existed, then knowledge layers (1) and (3) are at least arguably met. ${ }^{228}$

226 Manning, supra note 171 , at 691 (discussing concepts of intent in Raz, supra note 171). For a thorough exploration of the legislative supremacy underpinnings of statutory interpretation theories, see Daniel A. Farber, Statutony Interpretation and Legislative Supremacy, 78 GEO. L.J. 281 (1989).

${ }^{227}$ See John Ferejohn \& Barry Weingast, Limitation of Statutes: Strategic Statutory Interpretation, 80 GEO. L.J. 565 (1992) (assessing the implications of the "dynamic" tensions among enacting Congresses' goals, different views of later Congresses and statutory implementers, and judicial review).

${ }_{228}$ Thus, in the FDA tobacco case, the Court appropriately examined the interrela- 
A brief discussion is necessary here to elucidate further the distinction between legislative history and a statute's "historical context." Textualists' concern with self-referential or self-conscious creation of history for reviewing courts is arguably addressed if one instead embraces judicial examination of a statute's historical context without consideration of self-referential legislator statements. ${ }^{229}$ For example, in Casey, Justice Scalia could have disregarded legislator statements about the goal of responding to the Court's Alyesk a decision, yet still considered that decision's existence and the baseline set of interpretive presumptions prevailing in the lower courts before Alyeska. ${ }^{280}$ Historical analysis that ignores or skeptically examines self-referential statements of legislators regarding meaning poses a substantially lesser risk of encouraging legislators inclined to play the legislative history game derided by many textualists. ${ }^{231}$ Textualists might respond, with some basis, that a legislature responding to a particular phenomenon, agency rule, or court opinion, could include explicit textual reference to such a motivation, as occasionally occurs. ${ }^{232}$ Encouraging such statutory explicitness, however, would not be rooted as much in concerns about legislator misbehavior as in a goal of forcing legislative articulation not just of a new legal standard, but of the historical underpinnings of a law's linguistic choices. This is not an impossible goal, but to date it has not been a typical mode of legislating. It would also further a goal of legislative excellence, but it would not be intended to

tionships among laws regulating tobacco products. See supra Part I.B.3 (discussing the Brown $\mathcal{E}^{5}$ Williamson decision). Not only would legislators have given such potentially overlapping laws consideration, but the Court unavoidably had to consider how these various statutes were interrelated. The Court took a far less justifiable interpretive step, however, when it inferred a legislative intent to give the FDA no tobacco jurisdiction, based in part on later laws that contained no actual language regarding FDA power, as well as upon legislative partisans' statements arising in many contexts other than in codified laws.

${ }_{2229}$ As discussed in the succeeding section of this Article, concerns about potential judicial misbehavior remain where judges can engage in the one-Congress fiction.

${ }^{2 * 4}$ See supra Part I.B.2 (discussing the Court's disregard for historical context in the Case decision).

${ }_{231}$ Brown $\mathcal{F}$ Williamson is unusual in its substantial reliance on numerous politicai actors' views about the FDA's powers over tobacco taken well after 1938, despite these various actors' failure to place such jurisdiction-denying language in any post-1938 law. For reasons unknown, the Court's textualists join this opinion with nary a word of qualification or dissent disagreeing with the Court's heavy reliance on legislative history in the form of individuals' statements made well after the primary statute's enactment.

${ }_{282}^{2}$ See, e.g., Landgraf v. USI Film Prods., 511 U.S. 244, 250-51 (1994) (noting explicit references in the Civil Rights Act of 1991 to recent Court decisions interpreting Title VII of the Civil Rights Act of 1964). 
deter legislative manipulation of legal results through legislative history. ${ }^{233}$ Such a goal of requiring greater legislative detail might have the additional effect of reducing the amount of law enacted due to the greater difficulty in garnering enacting coalitions when legislative winners and losers are made more explicit. ${ }^{234}$

\section{Deterring Judicial Manipulation and Interstatutory References}

Textualists express equally substantial concern over interpretive methodologies allowing judges to manipulate their analysis of legislative history not to justify some objectively reasonable statutory interpretation but to further their own personal views. Their argument is that the greater the body of materials a court can draw on in interpreting a law, the greater the potential for judicial abuse. Confining judges to the statutory text and its objectively reasonable meaning, the argument goes, reduces this risk of manipulation. Were textualist judges merely to confine themselves to a single statute's text, this justification would at least make logical sense. When courts start to refer to materials other than the primary textual provision, however, they too have given themselves a more open interpretive field. Only if that field of reference materials is somehow confined is the risk of judicial abuse that ostensibly motivates textualists addressed. One need not delve deeply into recent Court decisions relying on dictionaries to see how that purportedly "objective" source of meaning merely serves as artillery, with the majority and dissenters engaging in battles of the dictionary definitions, on one occasion even seeking to explain a statute from the 1970s with reference to the 1766 Blackstone Commentaries, which in turn quoted the Digest of Justinian. ${ }^{235}$

${ }^{283}$ Creation of yet more "clear statement" rules and expectations of legislative explicitness might deter legislative "passing of the buck," a practice criticized by public choice scholars and advocates of less broad delegations, but it would also be in tension with the benefits of regulatory flexibility embraced in the Cheoron decision.

${ }^{234}$ See McCubbins et al., supra note 124 (exploring reasons legislators will use administrative structure and processes as well as citizen enforcement to further legislative goals, to reduce monitoring costs, and to defer or avoid thorny issues). Rendering law enactment more difficult might reflect judicial political preferences for less regulation, much as "quasi-constitutional" clear statement rules have been manipulated to further judges' ideology by way of "backdoor . . . constitutional activism." William N. Eskridge, Jr. \& Philip P. Frickey, Quasi-Constitutional Law: Clear Statement Rules as Constitutional Lawmaking, 45 VAND. L. REV. 593, 597-98 (1992).

${ }^{235}$ See Babbitt v. Sweet Home Chapter of Cmtys. for a Greater Or., 515 U.S. 687, 717 (1995) (Scalia, J., dissenting). For an example of the Court's battle over the use of dictionaries, compare MCI Telecomms. Corp v. ATETT, 512 U.S. 218, 224-28 (1994) 
Interstatutory references are similarly prone to judicial abuse. First, as utilized in the cases described and cited above, the body of potentially relevant comparisons of statutory provisions appears unlimited by time or subject matter. Any statute, whether it pre- or postdates the primary statutory provision, can be cross-referenced. It need not even concern the same field of regulation. Furthermore, either due to intentionally disingenuous judicial behavior or, perhaps, mere sloppiness, the Court's use of this interpretive technique often does not even include grappling with the Court's own previous interpretations of the primary or referent provisions. In most instances, texts are compared to texts, while other sources of enlightenment regarding historical context are ignored even when brought to the Court's attention. $^{236}$

The lack of rigorous grappling with materials other than the text may result from the way interpretations based on the one-Congress fiction cannot effectively be anticipated in the litigation process. If only a single statute is debated before a court, opposing counsel will each know the materials from which to draw. When the primary statute could be construed in light of any arguably similar law, however, advocates will not be able to predict which referents to research. The unpredictability this interpretive ploy creates is likely to lead advocates faced with briefing page limits to offer analysis that may be a mile wide but an inch deep. ${ }^{237}$ Perhaps this inability of advocates to anticipate which referents the Supreme Court would find relevant explains the sloppy cross-referencing evident in Bennett, Casey, and most other recent cases using this interpretive methodology.

A strong argument can be made that use of the one-Congress fiction is more prone to judicial abuse than is reference to legislative history. As a resource, legislative history can typically, or at least persuasively, only be cited if its own text reveals a view on the disputed statutory question. Interstatutory cross-referents, in contrast, need not contain any indication whatsoever that would cause anyone to expect that they would be used to assist in interpretation of another statute's disputed provisions. They are, in a sense, a form of history that no one could anticipate would be used in the context of debate over another law. In the legislative history context, coalitions engaged in

(Scalia, J.), with id. at 240-43 (Stevens, J., dissenting).

$2 * 4$, See supra Part I.B (discussing cases in which the Supreme Court made use of the one-Congress fiction without regard to historical context).

${ }_{237}$ See generally Martin S. Flaherty, History "Lite" in Modern American Constitutionalism, 95 COLUM. L. REv. 523 (1995) (discussing the pervasive superficiality of historical analysis in constitutional scholarship and Court opinions). 
statutory enactment battles will watch for overreaching statements regarding legislative intent and put their own responses in the record. ${ }^{238}$ Legislators abusing the ability to explain statutory meaning in a collective setting, such as a committee report, will also be noticed by others and, if the abuse continues, eventually no longer trusted to participate in such declarations of meaning. ${ }^{239}$ The adversarial process by which statutory disputes reach judges makes it likely that both pieces of legislative history will be placed before the court. ${ }^{240}$ A judge referring to such legislative history will, due to her sense of judicial craft and her obligation to draft a defensible opinion, only use historical materials that actually refer to the disputed statutory issue and be forced to grapple with supporting and contradictory legislative history. ${ }^{241}$ Furthermore, trial judges will worry about appellate reversal, while appellate judges must consider panel dissents or en banc or higher court reversal. Even for the lofty Supreme Court, academic critiques are likely to discern unjustified reliance on legislative history. Legislators and judges are thus constrained in which materials they can use and how they use them. Inferences from additions and omissions of particular language in different statutes, in contrast, are subject to no such similar constraints, apart from a judge's obligation to explain her rationale. That explanation, however, is far less constrained when the only materials before the court are two statutory texts. Mere similarity of language or statutory function appears to be enough of a potential trigger for interstatutory references and related inferences regarding meaning.

To put the previous paragraph's point differently, one can envi-

${ }^{238}$ See McNollgast, supra note 124, at 726 (arguing that "statements ... that are not contradicted or rejected at some later stage are implicitly approved by their parent chambers when the bill itself is approved").

${ }^{239}$ See id. (noting PPT's prediction that actors who engage in strategic behavior to try to shape legislative history can be sanctioned as the ultimate authority to make legislative decisions is always retained by the majorities of each house).

${ }^{240}$ See Sidney A. Shapiro \& Richard E. Levy, Judicial Incentives and Indeterminacy in Substantive Review of Administrative Decisions, 44 DUKE L.J. 1051, 1053-62 (1995) (analyzing how "craft" and "outcome" concerns influence judicial decisionmaking); Strauss, supra note 9, at 251-52 (suggesting reasons judges are constrained from misusing historical materials).

${ }^{241}$ See Shapiro \& Levy, supra note 240 , at 1053 (defining judicial craft as "the wellreasoned application of doctrine to the circumstances of a particular case ... reflect[ing] the values of consistency with constitutional and statutory provisions and continuity with prior case law, but permit[ting] interstitial evolution and, in exceptional cases, [the] overruling [of] precedent"); Zeppos, The Use of Authority, supra note 9, at 1135 (describing judges as risk-averse beings who seek as many bases of analytical support for their decisions as possible in order to avoid reversal). 
sion a disputed interpretive issue as calling for analysis similar to the discernment of the direction of data points on a graph. The primary statute's text creates data points to which any interpretation must conform. In the common setting of genuine uncertainty about statutory meaning, those data points are likely to be few and often will be inconclusive. Legislative history data points will frequently provide different potential arguments about appropriate interpretations, but when a judge who considers historical context interprets a disputed provision, that judge will need to examine text, historical context, and legislative history and then craft a judicial response that is defensible, taking all of these data points into account. Perhaps for this reason a majority of the Supreme Court still believes that some consideration of historical context and legislative history is appropriate, even if the statutory text is paramount. ${ }^{242}$ If a judge embraces an outlier that is inconsistent with other indications of statutory meaning, the resulting opinion will be attacked. Mere text-to-text comparisons, in contrast, provide virtually no constraining data points that a judge must evaluate and explain in reaching a result. The universe of ostensibly similar statutory provisions-frequently a huge universe-is putty for judicial molding. ${ }^{2 * 35}$

One additional risk of judicial abuse is posed by the one-Congress fiction. As in Bennett, each construction of a cross-referent creates dicta for future manipulation by judges and litigants. When the unanimous Court in Bennett construed citizen suit provisions in the Clean Water Act ("CWA") and several other statutes as distinguishable from, and narrower than, the Endangered Species Act's provision, that interpretation modified the likely future reach of the CWA. Furthermore, due to the Court's failure even to look at its own past interpretations of the CWA, the Court neglected to grapple with its own

${ }^{242}$ See Wisconsin Pub. Intervenor v. Mortier, 501 U.S. 597, 611-12 n.4 (1991) (demonstrating the majority's explicit rejection of the view that legislative history is irrelevant to statutory interpretation), discussed in ESKRIDGE \& FRICKEY, supra note 9, at 624-25. In Brown $\mathcal{F}^{2}$ Williamson, the justices do not explicitly explain why they viewed the case as appropriate for reference to such a wide range of legislative authorities, but all members of the Court joined opinions that delved deeply into legislative history and context, not just the primary statute's text. See supra Part I.B.3 (discussing Brown si Williamson).

24: Professor Merrill similarly observes that "[h]aving fewer tools to work with, the textualist-like the painter working with a small palett[e]-necessarily has to become more imaginative in resolving questions of statutory interpretation." Thomas W. Merrill, Textualism and the Future of the Chevron Doctrine, 72 WASH. U. L.Q. 351, 373 (1994), quoted in Strauss, supra note 9, at 254. 
previous opinions giving the CWA a broader interpretation. ${ }^{244}$ Embracing an interpretive technique that unavoidably will create dicta regarding a statutory provision not even before the court and unlikely to have received scrutiny from briefing poses a risk of unsettling other bodies of law and empowering judges to pursue their own policy preferences.

\section{Textualist Rejection of the Sounds of Legislative Silence}

Textualists typically refuse to draw inferences from legislative failures to overrule case law or agency interpretations of statutes and similarly question re-enactment of laws as revealing ratification of previous interpretations, unless actual evidence of such intent exists. ${ }^{245}$ This approach, too, is in tension with the one-Congress fiction interpretive technique. Justice Scalia has explicitly argued against the drawing of inferences from legislative inaction. ${ }^{246}$ Inaction could signify congressional approval of the status quo, but it might also simply reflect indifference or unawareness of the status quo or, perhaps, a divided view of the status quo. ${ }^{247}$ Similarly, in the context of the oneCongress fiction, courts are drawing inferences from congressional

${ }^{244}$ See supra notes $33-48,144-47$ and accompanying text (discussing the Supreme Court's construction of provisions in environmental laws regarding citizen litigation).

${ }^{245}$ For a decision in which Justice Scalia declined to apply the "re-enactment rule" due to the absence of a uniform preceding interpretation of the disputed language, see Pierce v. Underwood, 487 U.S. 552, 566-68 (1988). Justice Scalia stated, however, that where there has been consistent prior interpretation of particular language by the judiciary, then re-enactment of the same language "generally includes the settled judicial interpretation." Id. at 567.

${ }^{246}$ See, e.g., Johnson v. Transp. Agency, 480 U.S. 616, 671 (1987) (Scalia, J., dissenting) ("[W] e should admit that vindication by congressional inaction is a canard.").

${ }_{247}$ See id. ("[I]t [is] impossible to assert with any degree of assurance that congressional failure to act represents (1) approval of the status quo, as opposed to (2) inability to agree upon how to alter the status quo, (3) unawareness of the status quo, (4) indifference to the status quo, or even (5) political cowardice."). The majority subsequently embraced this argument, refusing to draw significance from legislative inaction in Patterson v. McLean Credit Union. 491 U.S. 164, 175 n.1 (1989) ("It is "impossible to assert with any degree of assurance that congressional failure to act represents' affirmative congressional approval of the Court's statutory interpretation." (quoting Justice Scalia's Johnson dissent)); see also United States v. Johnson, 481 U.S. 681, 703 (1987) (Scalia, J., dissenting) (criticizing again the drawing of inferences from legislative inaction as "an uncertain enterprise which takes as its starting point disregard of the checks and balances in the constitutional scheme of legislation designed to assure that not all desires of a majority of the Legislature find their way into law"). For more detailed arguments on this issue, see generally Eskridge, supra note 130. In Brown $\mathcal{E}^{\circ}$ Williamson, however, the Court's textualists did not dissent or state disapproval of the Court's substantial reliance on legislative actors' views that never found their way into new statutes. See supra Part I.B.3 (discussing Brown E' Williamson). 
adoption of particular language that could be embraced for a wide range of reasons. As discussed above, where the Court seeks to make its own interpretations of similar language consistent but also looks for indications of links between two cross-referenced provisions, the effort to maintain judicial consistency has a precedent in the in pari materia doctrine. For the same reasons that Justice Scalia has vociferously criticized drawing inferences from legislative silence, the oneCongress fiction should be shunned or, at least, warily applied.

\section{Dynamic Statutory Interpretation and the One-Congress Fiction}

Textualists contrast their mode of interpretation not only with that of judges willing to examine legislative history but also with that of advocates of "dynamic" modes of interpretation. ${ }^{248}$ The most prominent advocate of the latter methods is Professor Eskridge, but Professor Aleinikoff and former Yale Law School dean and current Judge Calabresi have also suggested, albeit in different formulations and with different rationales, that courts should, in essence, update laws by means of judicial interpretations. ${ }^{249}$ This is called "dynamic" interpretation in the sense that an unchanged text can be interpreted in a changed manner depending on "what it ought to mean in terms of the needs and goals of our present day society. "250 Justice Scalia's response to this suggested methodology is, first, to concede that it describes actual results in some cases. ${ }^{251} \mathrm{He}$ then dismisses this approach, stating that " $[\mathrm{i}] \mathrm{t}$ is simply not compatible with democratic theory that laws mean whatever they ought to mean, and that unelected judges decide what that is." ${ }^{252}$

As shown above, however, use of the one-Congress fiction allows a similarly liberating mode of interpretation. If courts can engage in interstatutory comparisons and draw inferences from textual comparisons alone without reference to historical context, even when the statutory referent post-dates the primary text at issue, courts can en-

${ }^{2}$ J Justice Scalia explicitly rejects what he characterizes as Professor Eskridge's embrace of dynamic statutory interpretation. SCALIA, supra note 4, at 22.

24: For their respective arguments, see generally CALABRESI, supra note 12; Aleinikoff, supra note 129.

SCAll Supra note 4, at 22 (quoting ESKRIDGE, supra note 12, at 50 (quoting Arthur W. Phelps, Factors Influencing Judges in Interpreting Statutes, 3 VAND. L. REV. 456, 469 $(1950))$ ).

\footnotetext{
2il See SCALIA, supra note 4, at 22.

2II Id.
} 
gage in just the same sort of ends-oriented interpretation that ignores evidence of intended meaning or some shared set of interpretive assumptions. Dynamic modes of interpretation in some vague sense at least call for fealty to a principal which appears, in various places, either to be the current Congress, prevailing societal views, or perhaps a judge's conception of current societal needs. The one-Congress fiction, in contrast, disregards loyalty to anything but the United States Code or a judge's own policy preferences, to the frequent exclusion of other legal authority such as regulations or case law. ${ }^{253}$ This point is not a justification for dynamic modes of interpretation, which $I$, for many of the reasons articulated by Professor Nagle, find troubling. ${ }^{254}$ Professor Eskridge asserts that Justice Scalia's "holistic textual analysis is no more determinate, objective, or constraining than other archaeological approaches to statutory interpretation." can convincingly make this point about all aspects of "holistic textual analysis" is debatable, but Eskridge is undoubtedly correct that the one-Congress fiction shares similar "judge-liberating" elements. This Article, however, does not conclude that both are therefore appropriate. Instead, this Article suggests that while interstatutory crossreferencing is appropriate in limited contexts, courts should generally abandon the one-Congress fiction.

\section{Textualism Revisited in Light of the One-Congress Fiction}

The one-Congress fiction's questionable logic illuminates the weak normative and empirical underpinnings of some broader claims about textualist modes of interpretation. The question remains, however, whether this critique merely reveals this interpretive move as a shoddy form of textualism or instead reveals pervasive problems with textualism. Much as this Article has suggested that examination of historical context and materials can enlighten without rewarding selfreferential manipulations of history, might the one-Congress fiction be textualism's analog to excessive reliance on legislator statements in legislative history? In other words, could one logically embrace many of textualism's claims and benefits and still reject this particular practice? This section briefly shows how at least a few of the one-Congress

${ }^{253}$ See Funk, supra note 9 , at $846-47$ (arguing that in the face of genuine statutory ambiguity, judges barred from examining legislative history who wish to act in good faith "must necessarily impose their view of the law on the law").

${ }^{254}$ See John Copeland Nagle, Newt Gingrich, Dynamic Statutory Interpreter, 143 U. PA. L. REV. 2209 (1995) (critiquing ESKRIDGE, supra note 12).

${ }^{255}$ ESKRIDGE, supra note 12, at 44. 
fiction's weaknesses are reflective of inherent flaws in several of textualism's basic tenets.

First and foremost, the inability to reason across statutory texts to reach interpretive inferences largely also holds true with text-only interpretations of a single statute. Any purported embrace of a statute's "plain meaning" in light of the text's ordinary meaning necessarily empowers a judge to utilize implicit interpretive assumptions, select among statutory canons, and even select among dictionary definitions. $^{256}$ Judges' preferences for specificity under textualist interpretive modes, for example, may trump legislative drafters' possible preference for a more open-textured delegation of agency power and hence frustrate legislative supremacy goals. ${ }^{257}$ Judicial consideration of context can constrain, rather than empower, judges in construing one statute or engaging in interstatutory cross-referencing. The common textualist fear that any consideration of historical or statutory context will unduly free judges to pursue their policy preferences is an overly broad assumption. Judges faced with tough interpretive tasks will need to look somewhere for guidance. Judges who look at the whole United States Code for interpretive inferences under the one-Congress fiction, or a wall of dictionaries and available definitions in interpreting a single statute, are freed to engage in creative reasoning from these largely indeterminate sources. ${ }^{258}$ It is far from obvious that sensitivity to context is more prone to abuse than is attention to text alone. ${ }^{259}$ The question is: What interpretive approaches are most

$250^{\circ}$ See Farber, supra note 193, at 552 ("Notably, from the drafter's perspective, the formalist approach suffers from defects like those of the most extreme anti-formalist approach, in which the primary factor in interpretation is the judge's view of public policy, with statutory language and legislative purpose receiving only subsidiary attention.").

${ }^{257}$ See id. at 551 (describing how such judicial preferences constrain the set of drafting options atherwise available to a legislative drafter). For example, Justice Breyer in his Brown $\mathcal{F}^{2}$ Williamson dissent suggests that the FDA's authority under the 1938 FDCA should have been construed in light of the enacting period's broad delegations of authority to agencies. FDA v. Brown \& Williamson Tobacco Corp., $120 \mathrm{~S}$. Ct. 1291,1318 (2000) (Breyer, J., dissenting). The majority, however, looks for language specifically empowering the FDA to regulate tobacco. Id. at 1300-01. For further discussion of Brown $\mathcal{E}$ Williamson, see supra Part I.B.3.

${ }^{25 .}$ See Funk, supra note 9, at 846-47 ("[W]e must ask the judge to read the statute like an ordinary person, albeit a learned and informed ordinary person."); Strauss, supra note 9, at 253 ("Knowledge of the political history of legislation and a disposition to be informed by it (in what are unmistakably the judiciary's own judgments) makes of the judiciary ... a more readily trusted agent.").

${ }_{234}$ Professor Farber convincingly suggests that judges and other law interpreters will, over time, build up sensitivity to context and become expert in discerning statutory patterns and associated policy implications. He therefore suggests that judicial 
likely to produce principled reasoning, constructive conversation among Congress, agencies, and courts, and sound results, rather than ends-oriented manipulation of interpretive methods and statutory materials? The one-Congress fiction is vulnerable to such manipulation, as are most text-only interpretive approaches.

The larger problem with textualism highlighted throughout this critique of the one-Congress fiction is neglect of the implications of the "legislative chaos" that produces legislation. ${ }^{260}$ Because Congress is a "they," not an "it," as argued by Judge Easterbrook and Professor Shepsle, and because this collective entity is invariably influenced by interest group pressures and complicated procedural and institutional hurdles, comprehensive rationality cannot be expected. For textualists like Judge Easterbrook, text must reign supreme because "intent" cannot be found and only the text is enacted into law. ${ }^{261}$ Such a view of Congress and legislation does not focus on wishful thinking that a tough-minded Court will discipline the unruly legislature. ${ }^{262}$ Under theories of politics rooted in the legislature's complex and collective identity, intent will not be found. Such views of the legislature do not rule out the possibility that tough interpretive questions might benefit from examination of historical context or a statute's objectively ascertainable purposes. ${ }^{263}$ For the same reasons that Congress's collective nature does not allow one to draw inferences from the one-Congress fiction about what Congress "knows how to do," rigorous judicial review is unlikely to lead to legislative excellence. The schools of textualism rooted in "demand side reductionism" err in failing to examine the implications of the complexities of the legislative process and of Congress's collective nature. ${ }^{264}$

attention to context will render choices made more predictable as interpreters develop what Karl Llewellyn called "situation sense." See Farber, supra note 193, at 556-58 (discussing the enigmatic question of how expertise develops). In contrast, Farber questions the wisdom of the "willful[] ignoran [ce]" called for by plain-meaning interpretive methods. Id. at 553.

${ }^{260}$ See generally Vincent Di Lorenzo, Legislative Chaos: An Exploratory Study, 12 YALE L. \& POL'Y REV. 425 (1994) (providing an overview of "chaos theory" as it applies to legislative activity).

${ }^{261}$ See Easterbrook, supra note 72, at 547 (concluding that any search for intent is indeterminate).

${ }^{262}$ See Schacter, supra note 35 (exploring how various "metademocratic" conceptions drive schools of statutory interpretation).

${ }^{263}$ See Shepsle, supra note 62, at 250-54 \& $\mathrm{n} .27$ (arguing that legislative intent does not exist but also suggesting that scrutiny of a statute's procedural history could assist judges in resolving tough interpretive questions).

Id. at 240-41 (describing Chicago-school public choice theory as asymmetric demand-side reductionism that focuses inordinately on interest group demands rather 
Finally, many statutory interpretation scholars emphasize the importance of predictable "interpretive conventions" against which the legislature can work..$^{2{ }^{25}}$ As shown above, however, courts' statutory interpretations reached by means of the one-Congress fiction cannot be predicted by even an omniscient drafter. Due to the complexities of the legislative process and Congress's collective nature as noted by public choice scholars, even a single statute is unlikely to be drafted with such interpretive conventions in mind. For textualists to denigrate the concept of "legislative intent," yet draw inferences based on comparisons of two statutes' provisions, is to disregard the very public choice skepticism motivating textualism's most basic tenets. This author believes that the goal of consistent and principled interpretive conventions is nevertheless appropriate, but I reach this conclusion only by taking into account other realities of legislation such as the role of professional staff and counsel, numerous checks on legislative history and judicial abuse, and politicians' desire to achieve political goals despite the many hurdles to political success. These additional factors influencing the process of drafting legislation may be viewed as inappropriate for consideration in the interpretive process by textualists, but it is difficult to expect even a modicum of rationality in legislation-let alone even occasional linguistic consistency in two or more laws-without taking these factors into account.

\section{MODIFY OR DISCARD THE ONE-CONGRESS FICTION?}

The one-Congress fiction is a text-based interpretive move, yet it undercuts textualism's strongest goals. When utilized only in text-totext comparisons, this interpretive move is highly manipulable and vulnerable to error. Both in theory and in practice, it has been used in ways that unnecessarily unsettle referent law. It also constitutes an odd or paradoxical anthropomorphizing of the legislature by justices who generally shun any references to legislative intent, decline to draw inferences from legislative silence, and criticize dynamic modes of interpretation. This interpretive move is particularly troublesome

than the "supply" side of politicians" incentives and the structures of political institutions).

See SCALIA, supra note 4, at 14-15; Farber, supra note 193, at 549 (stating that a primary goal of an interpretive method is to "give Congress a sure means by which it may work the people's will" (quoting Chisom v. Roemer, 501 U.S. 380, 417 (1991) (Scalia, J., dissenting))); Manning, supra note 171, at 690 ("[P]ositivist theories of interpretation suggest that 'legislative intent' has little to do with the genuine intentions of legislators, and much to do with legislators' intentions to enact statutes that will be interpreted according to accepted interpretive conventions."). 
when applied in a manner that no legislator could ever predict. To the extent the one-Congress fiction cases analyzed here reflect what Professors Popkin and Zeppos and Judge Posner refer to as an assumption of an omniscient and ideal legislative drafter, this interpretive move should be discarded. Nevertheless, this Article concludes that a far more limited and rigorous version of interstatutory crossreferencing is both inevitable and could be applied in a more neutral and defensible manner.

What would this more limited type of interstatutory crossreferencing look like? It would look much like the usual application of the in pari materia doctrine, with courts only making interstatutory comparisons where there was actual indication of a legislative expectation of such cross-references and with courts paying far more attention to their own previous interpretations of primary and referent provisions. In addition, courts would also need to look at other aspects of historical context of both the primary and referent provisions, particularly agency interpretations appearing to influence language choices. These limitations mean that the kind of random languageonly cross-references appearing in Bennett and Casey should be discarded. Promoting legislative excellence is a legitimate goal, but the cases examined in Part I reveal a mode of interpretation that could not be anticipated by legislators and that amounts to a highly manipulable interpretive move that, in reality, is not much of an interpretive convention at all. Analysis of actual historical context and the primary and referent statutes' separate "vertical" histories is needed to make this practice more predictable and grounded in reality.

Limited interstatutory references are unavoidable due to courts', particularly the Supreme Court's, necessary role in resolving disputes over statutory meaning. The Brown $\mathcal{E}^{\circ}$ Williamson Court, for example, could not avoid analysis of post-1938 laws regulating tobacco. ${ }^{266} \mathrm{Judi}-$ cial reinvention of the interpretive task in every case, even with respect to language shared in many statutes, would result in a garbled line of case precedents that would make legislating, regulating, and even litigating difficult. Judicial attention to the court's own handiwork remains an important goal, as it has always been under the in pari materia doctrine. Courts should still, however, only make judicial consistency a secondary goal to carrying out legislative intent as discerned from the reasonable objective meaning of statutory language, construed in light of that particular statute's history and context.

${ }^{260}$ For more detailed discussion of Brown E' Williamson, see supra Part I.B.3. 
Even without resorting to self-referential legislative history, courts can and should look at a statute's historical context. ${ }^{267}$ In an interesting quirk of judicial history, or perhaps reflecting the evolution of Justice Scalia's jurisprudence, a few of Justice Scalia's interstatutory reference opinions from the late 1980 s reflect a much more sensitive analysis of the historical context of both the primary and referent statutes. ${ }^{268}$ Justice Kennedy's opinion in Bragdon $v$. Abbott similarly provides an example of interstatutory cross-referencing that involves a much more complete examination of historical context. ${ }^{269} \mathrm{He}$ looks across to other bodies of law but searches for indications that such comparisons were before the legislature as well.

This limited embrace of interstatutory cross-references and the rejection of the one-Congress fiction reflect this author's wariness about any judicial approach to disputes over particular statutory provisions that seeks to make sense of the law as a whole. In this goal, Justice Scalia shares an aspiration with Professors Eskridge, Aleinikoff, and Dworkin. What each of these scholars would do with this authority differs, but all appear comfortable with the task. Justice Scalia calls for the judge to seize each interpretive opportunity and constrain not

${ }^{267}$ See Farber, supra note 193, at 55459 (defending practical reasoning and, with analogies to chess and other disciplines where expertise matters, suggesting that attention to the larger context leads to sounder results).

${ }^{2 t . x}$ See, e.g., Pierce v. Underwood, 487 U.S. 552, 563-68 (1988) (considering various contextual arguments in its interpretation of the phrase "substantially justified"); Kungys v. United States, 485 U.S. 759, 769-72 (1988) (engaging in a historical analysis of the concept of materiality). Justice Scalia also engaged in a more history-rooted analysis in a recent concurrence in Feltner $v$. Columbia Pictures Television, Inc, 523 U.S. 340 (1998). He concurred in the majority's judgment regarding the right to a jury trial under the Seventh Amendment in the context of a Copyright Act damages claim, but reached his conclusion with a concise but thorough examination of the vertical history of the Copyright Act and with reference to parallel provisions of a few preceding laws and judicial constructions of those laws. Id. at 355-59.

${ }^{2}, 4$ The Court had to construe the Americans with Disabilities Act ("ADA") to determine if it was applicable to an HIV-infected patient's claim against a dentist for failure to treat her in Bragdon v. Abbott, 524 U.S. 624 (1998). The Court delved into parallel provisions in previous statutes and "the views of various administrative agencies which have faced this interpretive question." Id. at 631 . This cross-statutory reference and examination of previous administrative interpretations was arguably required by the ADA's direction that "nothing in this chapter shall be construed to apply a lesser standard than the standards applied under title $V$ of the Rehabilitation Act of $1973 \ldots$ or the regulations issued by Federal agencies pursuant to such a title." Americans with Disabilities Act of 1990, 42 U.S.C. $\$ 12201$ (1994) (citation omitted). The Court went even further, however, by looking at the details of agency examinations of HIV and disability issues, legislative history indicating Congress's awareness of agency interpretations of earlier related laws, as well as judicial precedents concerning parallel definitions. 524 U.S. at 637-47. 
only wayward and possibly sloppy legislators but also ideologically motivated and untrustworthy judges. He then, in a display of cognitive dissonance, calls on these same judges to use each interpretive opportunity to create a sensible corpus juris unless the primary statute precludes such an effort.

The track record of recent one-Congress fiction cases should give all pause. Text-to-text comparisons have led the Court to disregard actually articulated intent, historical context, and the Court's own contradictory precedents. Courts should pay attention to their own precedents, but can any judge or body of judges know what line of statutory, regulatory, or case law might be unsettled by a text-to-text comparison that ignores the historical context of the referent? Furthermore, for reasons discussed above in Part I, any attempt to make interstatutory references and impose judicial order on different fields of regulation implemented by different agencies and enacted through different committees is particularly vulnerable to judicial error. Indeed, the embrace of mere text-to-text comparisons as an approach to determine statutory meaning and make sense of the law as a whole reflects an unsound overestimation of any judge's ability, regardless of that judge's considerable legal acumen and wisdom. Statutory law is not a closed system but an evolving process that necessarily involves different legislators, agency officials, presidents, courts, and social contexts. The United States Code is not the only source of law. Instead, legal partisans invariably will participate in the legislative process based on assessment of existing statutes, regulations, judicial opinions, and even the current and anticipated political climate. In such a multistage, complex game that is akin to an evolving conversation, participants in the process are likely to react to many more variables than mere linguistic choices in another statute. The assumption of such legislative attention to linguistic choices across bodies of law constitutes an unsound interpretive convention that cannot be anticipated by participants in the legislative process.

\section{CONCLUSION}

The one-Congress fiction interpretive technique should be abandoned and replaced with, at most, a more limited and historically rigorous version of interstatutory cross-referencing. The one-Congress fiction is a prevalent textual mode of interpretation in numerous Supreme Court cases, but this particular technique is vulnerable to misuse. It has led to interpretive leaps that disregard reasonably discernible legislative goals and misconstrue the import of referent laws' 
provisions. Paradoxically, one of the best arguments for judicial modesty and abandonment of such a desire to improve the law in each case comes from Justice Scalia himself. He states that it is inappropriate in a statutory age for judges to ask, "[w] hat is the most desirable resolution of this case, and how can any impediments to the achievement of that result be evaded?" ${ }^{270}$ The Court's use of the oneCongress fiction necessarily calls for just such an inappropriately expanded judicial role. A more modest judicial method that only warily makes interstatutory references, and only then with attention to the primary and referent provisions' historical context and implementation history, would be far more consonant with this limited and realistic view of the abilities of judges and the legislature. 
* $* * * * * *$ 